\title{
QUALITY OF WET DEPOSITION IN THE GRAND CALUMET RIVER WATERSHED, NORTHWESTERN INDIANA, JUNE 30, 1992-AUGUST 31, 1993
}

By Timothy C. Willoughby

Prepared in cooperation with the INDIANA DEPARTMENT OF ENVIRONMENTAL MANAGEMENT

U.S. GEOLOGICAL SURVEY

Water-Resources Investigations Report 95-4172

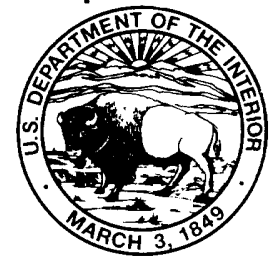

Indianapolis, Indiana 


\title{
U.S. DEPARTMENT OF THE INTERIOR BRUCE BABBITT, Secretary
}

\author{
U.S. GEOLOGICAL SURVEY \\ Gordon P. Eaton, Director
}

For additional information, write to:

District Chief

U.S. Geological Survey

Water Resources Division

5957 Lakeside Boulevard

Indianapolis, IN 46278-1996
Copies of this report can be purchased from:

U.S. Geological Survey

Earth Science Information Center

Open-File Reports Section

Box 25286, MS 517

Denver Federal Center

Denver, CO 80225 


\section{CONTENTS}

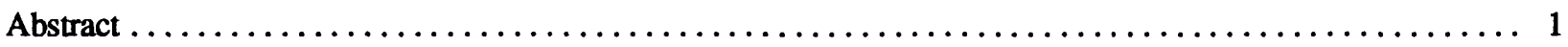

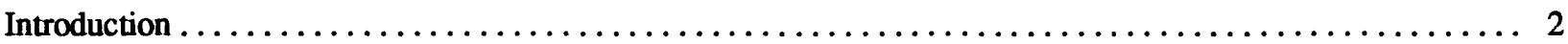

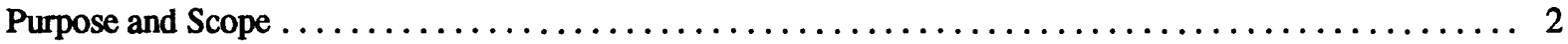

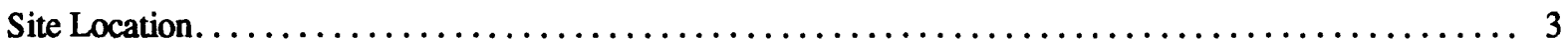

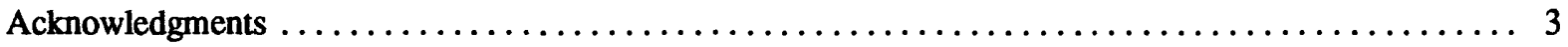

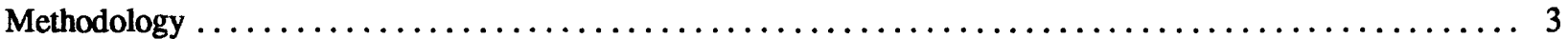

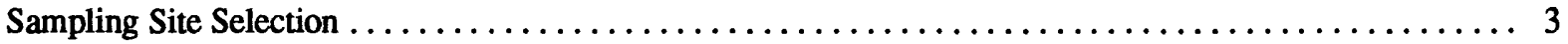

Constituent Selection and Analytical Techniques $\ldots \ldots \ldots \ldots \ldots \ldots \ldots \ldots \ldots \ldots \ldots \ldots \ldots \ldots \ldots$

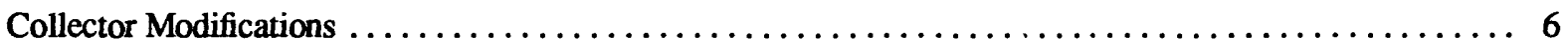

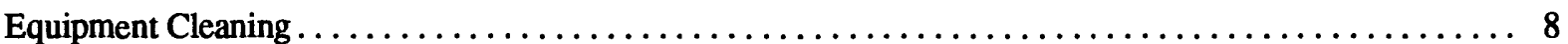

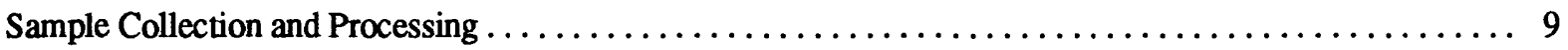

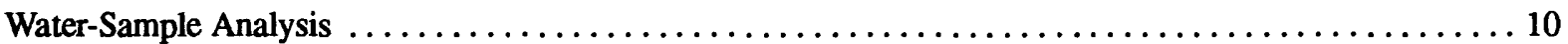

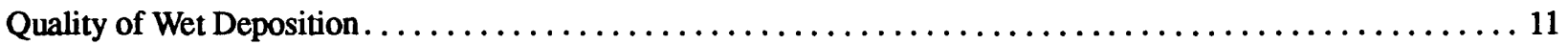

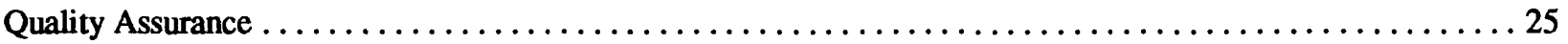

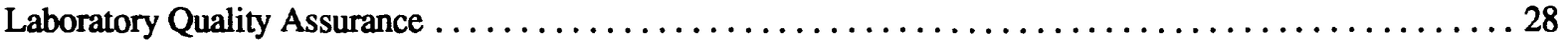

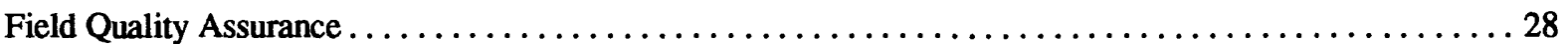

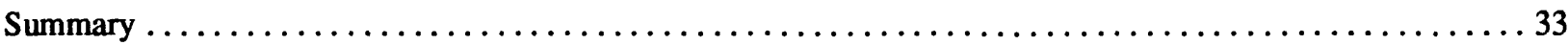

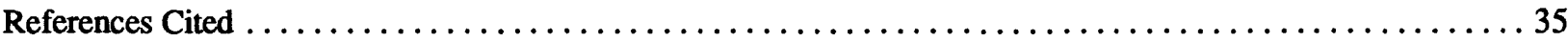

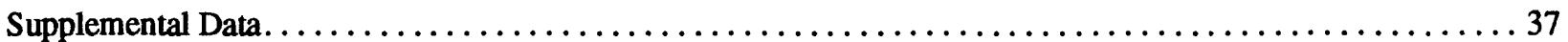

\section{FIGURES}

1. Map showing location of wet-deposition sampling site at the Gary (Indiana) Regional Airport ... 4

2. Diagram showing modified AeroChem Metric 301 wet/dry collector $\ldots \ldots \ldots \ldots \ldots \ldots \ldots$

3-4. Truncated boxplots showing:

3. Weekly wet-deposition amounts for the Gary (Indiana) Regional Airport . . . . . . . . . 13

4. Constituent concentrations for major ions measured in wet-deposition samples collected

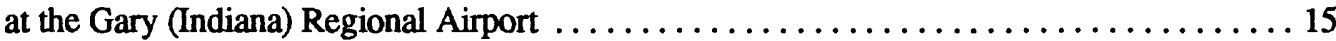

5. Map showing location of wet-deposition site at the Gary (Indiana) Regional Airport and two National Atmospheric Deposition Program sampling sites at the Indiana Dunes National Lakeshore and Huntington Reservoir . . . . . . . . . . . . . . . . . . . 16

6-7. Truncated boxplots showing:

6. Major ion concentrations measured in samples collected at the Gary (Indiana) Regional Airport and two National Atmospheric Deposition Program sites located at the Indiana Dunes National Lakeshore and Huntington Reservoir $\ldots \ldots \ldots \ldots \ldots \ldots \ldots \ldots \ldots \ldots$

7. Constituent concentrations for trace metals measured in wet-deposition samples collected at the Gary (Indiana) Regional Airport . . . . . . . . . . . . . . . . . . . . . . . . 19

8-9. Plots showing:

8. Estimated weekly major ion loadings determined from wet-deposition samples collected

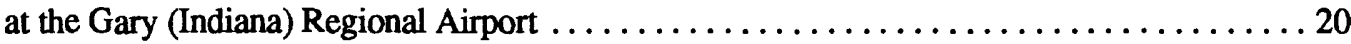

9. Estimated weekly trace-metal loadings determined from wet-deposition samples collected

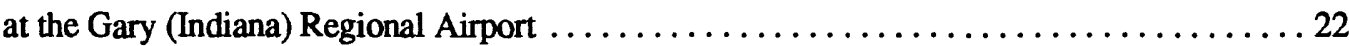




\section{CONTENTS}

\section{FIGURES Continued}

10. Map showing location of drainage area for the Grand Calumet River upstream from Kennedy Avenue, Indiana Department of Environmental Management surface-water stations, and the wet-deposition sampling site at the Gary (Indiana) Regional Airport . . . . . . . . . . . 26

11. Median constituent concentrations computed for the deionized-water funnel rinses and the acidified deionized-water funnel rinses compared to the median constituent concentrations computed for the wet-deposition samples and the method reporting limit $\ldots \ldots \ldots \ldots \ldots \ldots 31$

TABLES

1. Constituent, method of analysis, and the method reporting limits for the 29 constituents analyzed from samples collected at the Gary (Indiana) Regional Airport . . . . . . . . . . . 12

2. Water-quality characteristic measured; number of samples measured for that characteristic; number of samples measured greater than the method reporting limit; and the 25th, 50th, and 75th percentile rankings for wet-deposition samples collected at the Gary (Indiana) Regional Airport. .......................................... 14

3. Range for the estimated annual loadings determined from wet-deposition samples collected at the Gary (Indiana) Regional Airport for 1 year beginning June 30, $1992 \ldots \ldots \ldots \ldots \ldots \ldots 27$

4. Constituent measured; 25th, 50th, and 75th percentile rankings; and F-pseudosigmas for

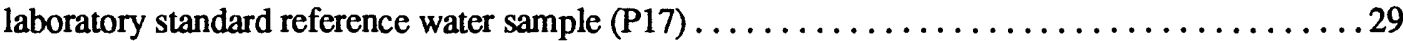

5. Comparison among median concentrations for the standard reference water sample (T117) funnel rinse processed at the Gary (Indiana) Regional Airport, median concentrations for the laboratory standard reference water sample (T117), and reported concentrations and F-pseudosigmas for standard reference water sample (T117)

6. Reported concentrations for wet-deposition samples collected at the Gary (Indiana) Regional

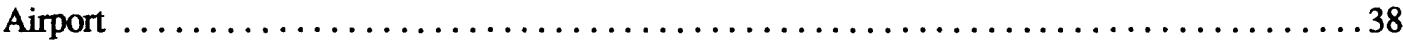

7. Reported concentrations for laboratory quality-control samples processed at the U.S. Geological Survey office laboratory in Indianapolis, Ind.

8. Reported concentrations for field quality-control samples processed at the Gary (Indiana)

Regional Airport 


\begin{tabular}{rll}
\hline Multiply & By & To Obtain \\
\hline centimeter $(\mathrm{cm})$ & 0.394 & inch \\
gram $(\mathrm{g})$ & 0.0353 & ounce \\
hectare (ha) & 2.471 & acre \\
kilogram $(\mathrm{kg})$ & 2.205 & pound \\
kilometer $(\mathrm{km})$ & 0.6214 & mile \\
$\operatorname{liter}(\mathrm{L})$ & 1.057 & quart \\
meter $(\mathrm{m})$ & 3.281 & feet \\
microgram $(\mu \mathrm{gg})$ & $3.530 \times 10^{-8}$ & ounce \\
milligram $(\mathrm{mg})$ & $3.530 \times 10^{-5}$ & ounce \\
milliliter $(\mathrm{mL})$ & 0.03381 & ounce, fluid \\
millimeter $(\mathrm{mm})$ & 0.0394 & inch \\
\hline
\end{tabular}

Temperature is given in degrees Celsius $\left({ }^{\circ} \mathrm{C}\right)$ which can be converted to degrees Fahrenheit $\left({ }^{\circ} \mathrm{F}\right)$ as follows:

$$
{ }^{\circ} \mathrm{F}=1.8 \mathrm{x}^{\circ} \mathrm{C}+32
$$

Sea level: In this report, "sea level" refers to the National Geodetic Vertical Datum of 1929 (NGVD of 1929)-a geodetic datum derived from a general adjustment of the first-order level nets of the United States and Canada, formerly called Sea Level Datum of 1929.

\begin{abstract}
Abbreviated water-quality units used in this report: Chemical concentrations and temperature are given in metric units. Chemical concentration is given in milligrams per liter $(\mathrm{mg} / \mathrm{L})$ and micrograms per liter $(\mu \mathrm{g} / \mathrm{L})$. Milligrams per liter is a unit expressing the concentration of chemical constituents in solution as weight (milligrams) of solute per unit volume (liter) of water. One thousand micrograms per liter is equivalent to one milligram per liter. Loadings are reported in kilograms per hectare $(\mathrm{kg} / \mathrm{ha})$ and grams per hectare $(\mathrm{g} / \mathrm{ha})$.
\end{abstract}

Specific conductance of water is expressed in microSiemens per centimeter at 25 degrees Celsius $(\mu \mathrm{S} / \mathrm{cm})$. This unit is equivalent to micromhos per centimeter at 25 degrees Celsius $(\mu \mathrm{mho} / \mathrm{cm})$, formerly used by the U.S. Geological Survey.

Volume of samples is given in liters $(\mathrm{L})$. 


\title{
QUALITY OF WET DEPOSITION IN THE GRAND CALUMET RIVER WATERSHED, NORTHWESTERN INDIANA, JUNE 30, 1992-AUGUST 31, 1993
}

\author{
By Timothy C. Willoughby
}

\section{Abstract}

Northwestern Indiana is one of the most heavily industrialized and largest steelproducing areas in the United States. High temperature processes, such as fossil-fuel combustion and steel production, release contaminants to the atmosphere that may result in wet deposition being a major contributor to major ion and trace-metal loadings in northwestern Indiana and Lake Michigan. A wet-deposition collection site was established at the Gary (Indiana) Regional Airport in June 1992 to monitor the chemical quality of wet deposition.

Weekly samples were collected at this site from June 30, 1992, through August 31, 1993, and were analyzed for $\mathrm{pH}$, specific conductance, and selected major ions and trace metals. Forty-eight samples collected during the study were of sufficient volumes for at least some of the determinations to be performed. Median constituent concentrations were determined for samples collected during warm weather (April 1 through October 31) and during cold weather (November 1 through March 31). These median concentrations then were substituted for missing values from samples collected during the same periods with insufficient volumes for analysis of all the con- stituents of interest. Constituent concentrations were converted to weekly loadings. Two values were calculated to provide a range for the weekly loading for samples with measured concentrations of constituents less than the method reporting limit. The minimum weekly loading was computed by substituting zero for the constituent concentration, and the maximum weekly loading was computed by substituting the method reporting limit for the concentration. If, for a constituent, all of the sample concentrations measured were greater than the method reporting limit, a single annual loading value was computed. Ranges for the annual loadings for samples collected at the Gary (Indiana) Regional Airport, calculated by summing the minimum and maximum weekly loadings, were determined for sulfate (26.0 to 26.4 kilograms per hectare), copper (9.9 to 11 grams per hectare), and lead (10 to 11 grams per hectare). A single annual loading value was computed for manganese (69 grams per hectare) and zinc ( 24 grams per hectare). These annual loadings could be used to assist in estimating the contribution of wet deposition to the total annual constituent loadings in the Grand Calumet River in northwestern Indiana. 


\section{INTRODUCTION}

The Great Lakes compose the largest area $\left(244,000 \mathrm{~km}^{2}\right)$ of fresh water on Earth (Herdendorf, 1982). This important natural resource for the United States and Canada is managed under the 1972 Great Lakes Water Quality Agreement. This agreement describes the need for surveillance, monitoring, and research activities to protect and, if necessary, to reclaim the chemical and physical quality of the Great Lakes Basin (Klappenbach, 1991). The chemical composition of wet deposition is affected by the chemistry of atmospheric aerosols and airborne particles (Schroder and others, 1989). Contaminants are deposited to the surface as components of wet deposition and dry deposition. Wet deposition is rain, snow, sleet, dew, and hail; dry deposition is dust. In the early 1970's, Shiomi and Kuntz (1973) recognized the importance of wet and dry deposition to the chemical quality of the Great Lakes.

The two major processes that introduce contaminants to wet deposition are rainout and washout. Rainout is the process that occurs in clouds, such as condensation, nucleation, or gas dissolution. Washout is the process that scavenges the airborne particulates between the cloud base and the ground. During a wet-deposition event, both of these processes probably occur continuously because most storms produce convective air-current components that add large masses of near-surface air to overlying clouds (Schroder and Hedley, 1986).

For the past 20 years, much of the emphasis regarding the effects wet deposition has on the environment has been in the research and monitoring of the major ions found in wet deposition and how these constituents affect acid rain. One of the largest monitoring efforts currently is being conducted by the National Atmospheric Deposition Program (NADP). The NADP has monitored the major ion constituents of wet deposition since 1978. These data are collected at over 200 sites to monitor the spatial and temporal trends in the chemical composition of acidic wet deposition (Galloway and others, 1978). The NADP, however, does not analyze samples for trace metals.
In recent years, an increasing emphasis on the effects of the trace-metal components in wet deposition has emerged.

Wet and dry deposition may be a major component to nonpoint-source pollution. Northwestern Indiana is the State's highest priority area for nonpoint-source pollution control (Indiana Nonpoint Source Task Force, 1989). Some of the recommendations made by the Indiana Nonpoint Source Task Force are to evaluate and quantify water-quality impacts of airborne pollutants in inland waters and Lake Michigan, cooperate in Great Lakes air-monitoring programs, initiate a statewide monitoring program for airborne toxic and acid pollutants, improve integration of State air- and water-pollution control programs, and develop and implement enhanced air-pollution control strategies. To evaluate some of these recommendations, the U.S. Geological Survey (USGS) established a wet-deposition collection site at the Gary (Indiana) Regional Airport (hereafter referred to as the Gary airport) in June 1992 to monitor the chemical quality of wet deposition. This project was done in cooperation with the Indiana Department of Environmental Management (IDEM).

\section{Purpose and Scope}

This report describes the chemistry for $\mathrm{pH}$, specific conductance, and selected major ions and trace metals found in wet-deposition samples collected at the Gary airport from June 30, 1992, to August 31,1993 . In addition, this report:

(1) displays truncated boxplots (Helsel and Hirsch, 1992) showing the distribution of constituent concentrations;

(2) presents estimated weekly and annual loadings for the measured constituents and describes how these loadings could be used to assist in calculating the nonpoint-source contribution of wet-deposition loadings to the total constituent loadings in the Grand Calumet River; 
(3) compares the results of major ion concentrations found in wet deposition with results from two NADP sites (Indiana Dunes National Lakeshore and Huntington Reservoir) located in northern Indiana. This comparison is intended to evaluate if the chemistry of wet-deposition samples collected at the Gary airport is localized or if the chemistry of these samples is consistent with sites outside the industrialized Gary area; and

(4) describes the results for 52 qualityassurance samples and their effect on interpretation of the constituent concentrations measured in wetdeposition samples collected during this study.

\section{Site Location}

The wet-deposition sampling site was located at the Gary airport, a small airport that services mainly privately owned aircraft. Gary is in northwestem Indiana (fig. 1) and is one of the most industrialized areas in the United States. Major industries located near the sampling site include steel manufacturing, petroleum refining, smelting operations, and coal-fired electric-generating plants.

The wet-deposition sampling site is located at an altitude of $178 \mathrm{~m}$ above sea level, approximately 400 m north of Interstate $90,3.5 \mathrm{~km}$ south of Lake Michigan, and $18 \mathrm{~km}$ west of the Lake and Porter County boundary. The sampling equipment, an AeroChem Metric $301^{1}$ wet/dry collector and a Belfort weighing rain gage, was located $30.5 \mathrm{~m}$ north of the traffic control tower at the Gary airport. Air traffic at the airport did not pass over the sampling equipment. Access to the equipment was by an improved single-lane road within the secured grounds of the airport.

\footnotetext{
${ }^{1}$ Any use of trade, product, or firm names in this publication is for descriptive purposes only, and does not imply endorsement of products by the U.S. Government.
}

\section{Acknowledgments}

The author acknowledges the efforts of Gary Depositar of the IDEM for his help in locating an acceptable sampling site. The staff at the Gary airport provided access to the sampling site and assisted with shipping samples to the USGS office in Indianapolis, Ind. The author also thanks the project assistant, Robert E. Sheffer, for his efforts in servicing the sampling equipment.

\section{METHODOLOGY}

This section describes the selection of the sampling site, constituents selected and the analytical methods used to measure their concentrations in the samples, and the modifications made to the AeroChem Metric 301 wet/dry collector that were necessary for the collection of trace metals in wet deposition. No modifications were necessary for the collection and analysis of the major ions. This section also describes the methods used for cleaning the equipment and for processing and analyzing the samples.

\section{Sampling Site Selection}

The sampling site was chosen in cooperation with the IDEM. The decision to locate the sampling site at the Gary airport was based on the need to minimize the possibility of local point sources that could directly affect wet-deposition chemistry. The airport site also provided a secure location for the sampling equipment, an electrical power source, an open flat field with no obstructions projecting onto the collector or rain gage with an angle greater than 45 degrees from horizontal as recommended for the NADP. The sampling equipment was installed in accordance with NADP protocols (Bigelow, 1984).

\section{Constituent Selection and Analytical Techniques}

Calcium, magnesium, sodium, potassium, sulfate, chloride, and nitrate are constituents measured in samples collected by the NADP 

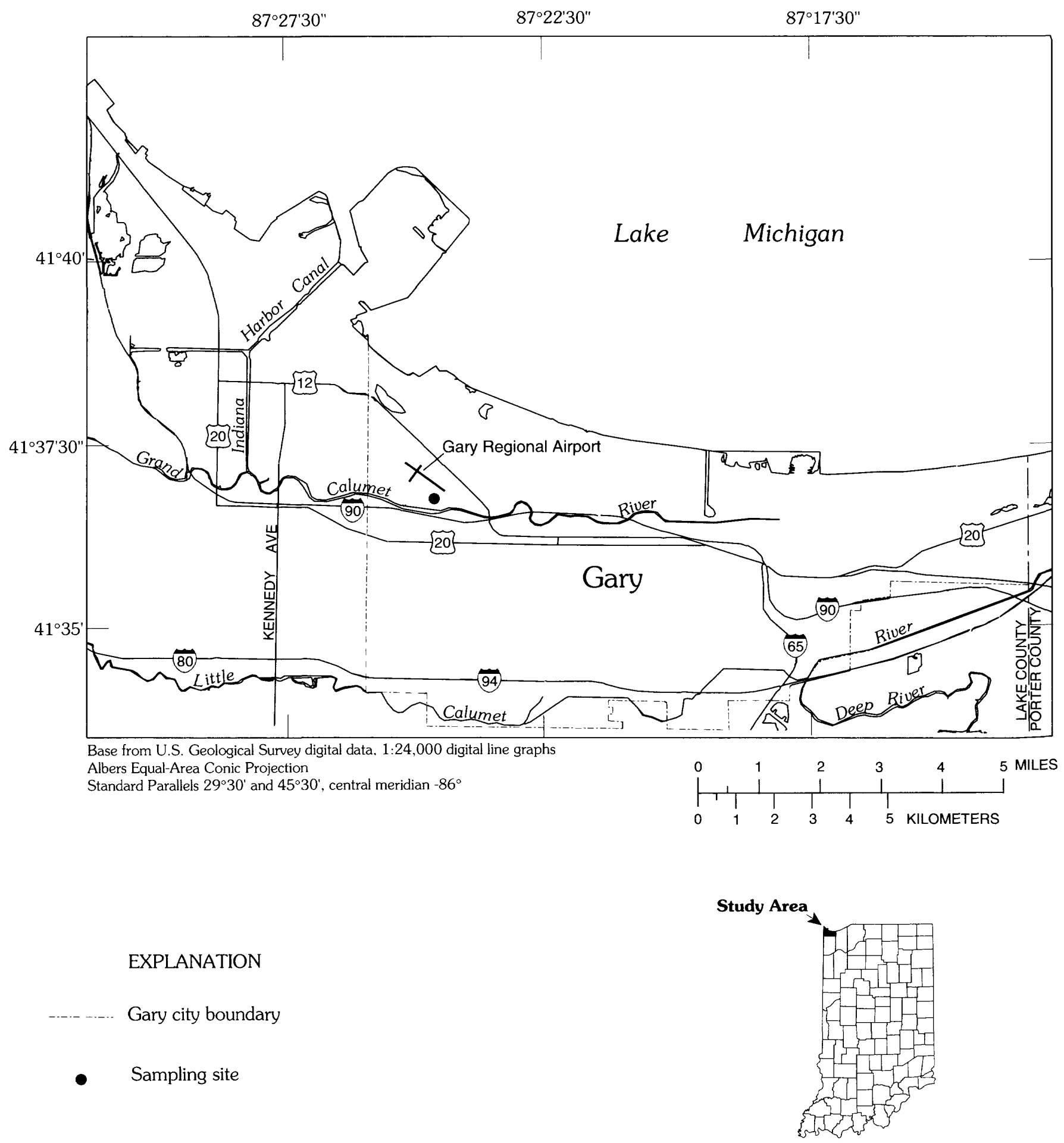

Figure 1. Location of wet-deposition sampling site at the Gary (Indiana) Regional Airport. 
for acid-rain studies. These constituents were analyzed in the Gary airport wet-deposition samples to evaluate their differences with the concentrations measured at the NADP sites located at the Indiana Dunes National Lakeshore and Huntington Reservoir. The Indiana Dunes National Lakeshore site is located approximately $26 \mathrm{~km}$ east of the Gary airport, and the Huntington Reservoir site is located approximately $180 \mathrm{~km}$ southeast of the Gary airport. The only major constituent analyzed by the NADP that was not analyzed during this study was ammonia. All analytical techniques utilized for this study were standard USGS methods for determination of inorganic substances in water. All of the following methods are described in Fishman and Friedman, 1989. Calcium (method I-1152-85, p. 137-139), magnesium (method I-1454-85, p. 275-276), sodium (method I-3736-85, p. 427-428), and potassium (method I-1630-85, p. 393-394) were analyzed by flame atomic absorption spectrometry. Major anions (sulfate, chloride, fluoride, bromide, and nitrate) were analyzed by ion chromatography (method I-2058-85, p. 527-530).

The trace metals measured for this study (because they are by-products of industrial processes located in the Gary, Ind., area and because of their toxic potentials) included arsenic, cadmium, copper, lead, manganese, mercury, and zinc. Although copper, manganese, and zinc are necessary for proper cellular development, these metals may bioaccumulate, especially in aquatic organisms, and therefore may present a health risk (Amdur and others, 1993). Arsenic, cadmium, lead, and mercury are not essential metals, and exposure at very low concentrations may present a risk.

Following are brief descriptions of possible sources for arsenic, cadmium, copper, lead, manganese, mercury, and zinc in northwestern Indiana and the analytical techniques used to analyze for these trace metals.
Arsenic is released to the atmosphere by fossil-fuel combustion, smelting, and the spraying of arsenical herbicide sprays. Arsenic is bioconcentrated by organisms but is not biomagnified in the food chain (Eisler, 1988). Arsenic was analyzed by atomic absorption spectrometry, hydride formation (method I-2062-85, p. 77-81).

Cadmium is released to the environment by fossil-fuel combustion, smelting, electroplating or galvanizing, and the production of nickelcadmium batteries (Amdur and others, 1993). Cadmium was analyzed by graphite furnace atomic absorption spectrometry (method I-1137-85, p. 129-132).

Copper is one of the more widely used trace metals and is released to the atmosphere by fossilfuel combustion, smelting, and steel manufacturing. Copper was analyzed by graphite furnace atomic absorption spectrometry (method I-1272-85, p. 197-200).

Lead is released to the atmosphere by fossilfuel combustion, combustion of lead-containing automobile exhaust or industrial emissions, and the manufacturing of lead batteries. Lead is in the atmosphere as either particulates of lead dioxide or in the form of vapors, particularly alkyl lead. Lead was analyzed by graphite furnace atomic absorption spectrometry (method I-1401-85, p. 249-252).

Manganese and its compounds are released to the environment in the manufacturing of steel alloys, dry-cell batteries, electrical coils, and ceramics. Other sources for manganese include fertilizers, oxidizing agents, and animal food additives. Manganese was analyzed by graphite furnace atomic absorption spectrometry (method I-1455-85, p.277-280).

Mercury appears in nature in three forms: elemental mercury and inorganic and organic compounds. The major source of mercury in the atmosphere is from the natural degassing of the Earth's crust, including land areas, rivers, and oceans. Elemental mercury in the atmosphere represents the major pathway of global mercury 
transport. Other sources of mercury include fossil-fuel combustion, mining, smelting, and emission from paper pulp industries. Regardless of the source, organic and inorganic forms of mercury may undergo environmental transformations. Elemental mercury may be oxidized to inorganic divalent mercury, such as what occurs in an aquatic environment. When conditions are appropriate for reducing reactions, divalent inorganic mercury may be reduced to elemental mercury. Divalent mercury also may undergo methylation to dimethyl mercury which can diffuse into the atmosphere and be redeposited to the biosphere as methyl mercury in wet deposition. Methyl mercury is the most toxic form of mercury and is known to bioaccumulate in aquatic biota (Amdur and others, 1993). Mercury was analyzed by flameless atomic absorption spectrometry, cold vapor (method I-2462-85, p. 289-291).

Zinc is released to the atmosphere by fossilfuel combustion, steel manufacturing, smelting, and galvanizing processes. Zinc was analyzed by graphite furnace atomic absorption spectrometry (method I-1901-85, p. 509-511).

In addition to the seven trace metals mentioned above, samples collected at the Gary airport also were submitted for analysis by inductively coupled argon plasma atomic emission spectrometry (ICAP). The ICAP method provides concentrations for a large number of trace metals during a single analytical run (method I-1472-85, p. 517-522). The ICAP method was used in this study to determine if any other trace metals could be included in future studies. The ICAP method included measurement of iron and silica. Iron and silica, because of the steel industry and the silicabased soils in northwestern Indiana, may be two of the more abundant constituents measured in the wet deposition at the Gary airport.

\section{Collector Modifications}

For the collection of trace metals, it was necessary to modify the standard AeroChem Metric 301 wet/dry collector. Teflon was used whenever possible for components of the collector that came in contact with wet deposition. Teflon is the preferred material for trace-metal collection and storage, especially for mercury and zinc (Fogg and Fitzgerald, 1979). Glass is also an acceptable material for the collection and storage of samples containing mercury. Glass bottles were used to ship the sample aliquot used for the analysis of mercury to the laboratory. Polyethylene or Teflon are excellent materials for the collection and storage of major ions in wet deposition.

The AeroChem Metric 301 wet/dry collector was modified to decrease the possible sources of trace-metal contamination to the sample (fig. 2). The bottom of the collector was enclosed with aluminum sheeting to house the collection bottle and thermometer. Holes were drilled through the sides of this enclosure and covered with a polyethylene screen to allow for cooling in summer; the screen helped prevent contaminants from blowing into the enclosure. The lid and lid arms of the collector were coated with Teflon to minimize contamination from wet deposition splashing off the lid and/or lid arms into the collection funnel (Dossett and Bowersox, 1991). The bottom of a 13-L polyethylene bucket was removed and a hole was cut through the collector frame to allow the collection funnel to pass through the collector frame into the bottom enclosure. A 31-cm diameter high-density polyethylene funnel was installed so that the funnel rested on the top of the 13-L polyethylene bucket. The bucket housing was adjusted so that the polyethylene-covered foam pad, attached to the bottom of the collector lid, fit tightly against the top of the funnel. This polyethylene foam pad assisted in preventing contaminants from blowing into the funnel when the sampler lid was closed. A fitting was attached to a silicon stopper in the bottom of the funnel to allow a $1.3-\mathrm{cm}$ Teflon tube to connect to the funnel. The Teflon tube then passed through a $1.3-\mathrm{cm}$ hole in the cap of a $5-\mathrm{L}$ Teflon collection bottle. Two 100-watt light bulbs were installed as close as possible to the hole cut in the collector frame. These two light bulbs were 


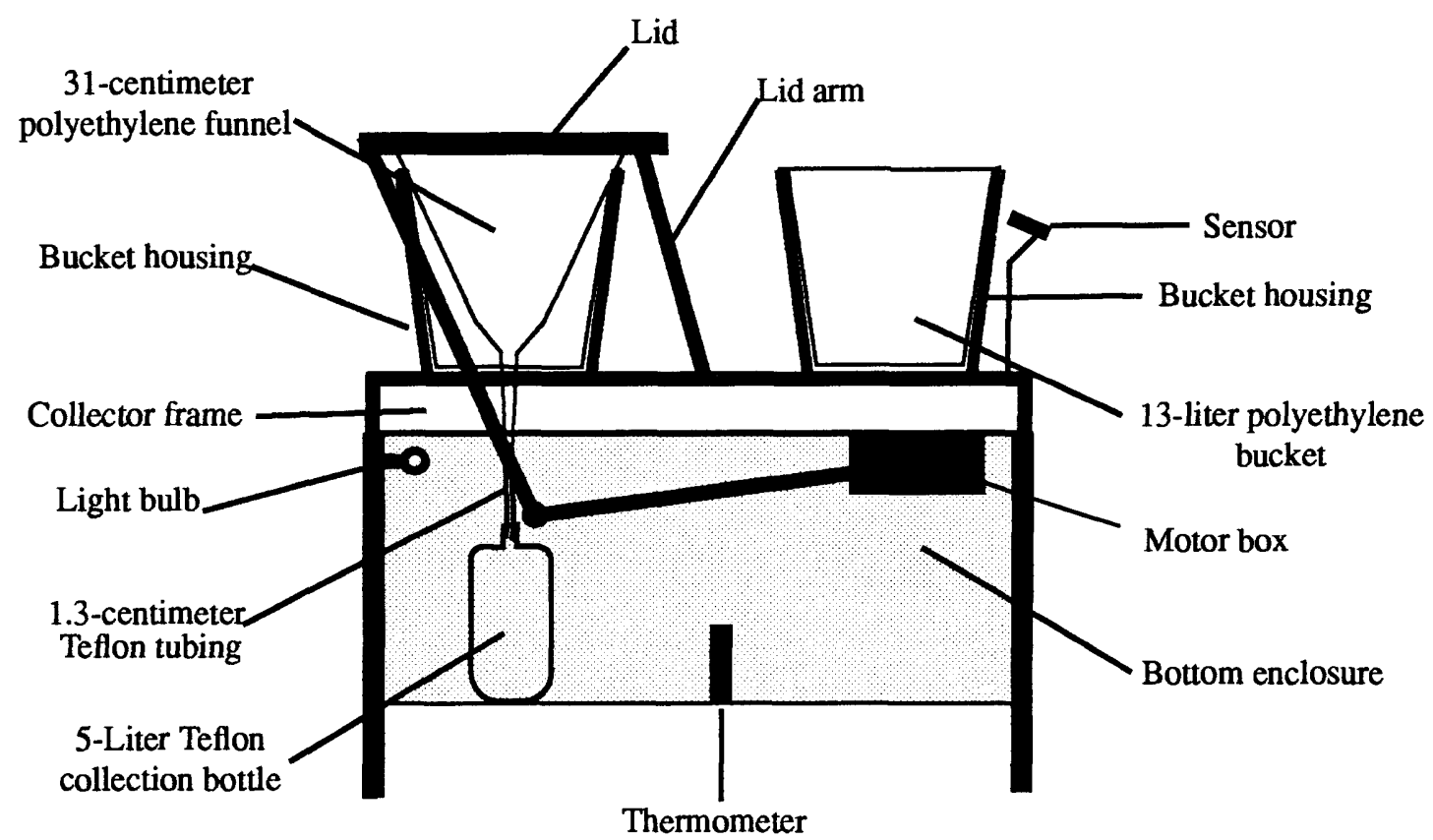

Figure 2. Modified AeroChem Metric 301 wet/dry collector. 
connected to a thermostat and were used to heat the area around the collection funnel to avoid snow and ice buildup in the funnel. Light bulbs were used instead of an electric heater to prevent possible contamination from the heating of copper wires. The thermostat was set to activate at about $5^{\circ} \mathrm{C}$.

The collector was activated by a sensor consisting of a metal plate separated by approximately $1 \mathrm{~mm}$ from a metal grating. When wet deposition came in contact with the sensor, the wet deposition was trapped between the metal plate and the metal grating, completing an electrical circuit and opening the lid of the collector. When the lid of the collector was open, the metal plate on the sensor heated to approximately $50^{\circ} \mathrm{C}$ to melt snow and to evaporate the trapped wet deposition, breaking the electrical circuit and closing the collector lid after the wet-deposition event had ended.

\section{Equlpment Cleaning}

All of the equipment cleaning was done in the laboratory located at the USGS office in Indianapolis, Ind. The 5-L Teflon collection bottles were cleaned with deionized water (DIW); the bottles were rinsed three times, filled, and then leached for 24 hours. All DIW used for this study met the National Institute for Standards and Technology type 1 standard (greater than $16.7 \mathrm{megOhm})$. The bottles then were rinsed three more times with DIW and filled with a 10-percent nitric-acid and DIW solution and leached for an additional 24 hours. All of the nitric acid used for cleaning and sample preservation was Ultrex-grade nitric acid. The bottles then were rinsed three more times with DIW, filled, and leached for 24 hours. The bottles were rinsed a third time with three aliquots of DIW, and the excess water was shaken from the bottle and the bottles were stored in a sealed prerinsed polyethylene bag.
The funnels were rinsed three times with large amounts of DIW. Any debris attached to the sides of the funnel was removed with a plastic brush. The funnels were rinsed again with DIW, followed by a 1-L rinse with a 10-percent nitric-acid and DIW solution. The funnels then were rinsed a final time with DIW and stored in a sealed prerinsed polyethylene bag.

The Teflon tubing was rinsed three times with large amounts of DIW, followed by three 100 -mL rinses with a 10 -percent nitric-acid and DIW solution. The Teflon tubing then was rinsed a final time with DIW and stored in a sealed, prerinsed polyethylene bag.

The 250-mL Teflon and glass bottles used to ship the samples to the laboratory were cleaned in the same manner as described previously for the 5-L collection bottles. The aliquot of the sample used for the determination of major anion concentrations was shipped to the laboratory in high-density polyethylene bottles. Because nitrate was one of the major ions measured during this study, no acid-rinsing techniques were used on the polyethylene bottles. New $250-\mathrm{mL}$ polyethylene bottles were rinsed three times with DIW, filled, and leached for 24 hours. The polyethylene bottles then were rinsed an additional three times with DIW. The 250-mL Teflon, glass, and polyethylene bottles were stored at the USGS office laboratory in Indianapolis, Ind.

The filters were cleaned immediately before use; the filters were rinsed with $50 \mathrm{~mL}$ of a 10 percent nitric-acid solution followed by three $50-\mathrm{mL}$ rinses with DIW. The filters then were rinsed with $20 \mathrm{~mL}$ of the sample before the sample was filtered into the $250-\mathrm{mL}$ bottles.

The collector was cleaned weekly when the samples were removed. The lid, lid arms, polyethylene lid pad, and the top of the collector frame were wiped clean with a lint-free paper towel and DIW to remove dust and debris that collected during the previous sampling week. The cleaning of the sampler was performed after the sample had 
been removed from the collector and before a clean funnel was installed for the next week of sampling to minimize any possible contamination resulting from the paper towel.

\section{Sample Collection and Processing}

Wet-deposition samples were removed from the collector every Tuesday. The Tuesday to Tuesday sampling period was consistent with the sampling period used by the NADP (Bigelow and Dossett, 1988).

A clean 5-L Teflon collection bottle, funnel, Teflon tube, approximately $1 \mathrm{~L}$ of deionized water (used for cleaning the collector), and any other equipment needed at the sampling site were packed in a cooler and sealed with packing tape. The cooler was shipped to the airport by an overnight mailing service. Field personnel would obtain the sealed cooler from airport employees every Tuesday. Approximately every other week an additional clean collection bottle, funnel, Teflon tube, and a quality-control sample also were shipped to the airport. Processing of the quality-control samples is discussed in the Field Quality Assurance section of this report.

Field personnel took every possible precaution to minimize contamination when removing the sample and installing clean equipment in the collector. These precautions included field personnel always wearing polyethylene gloves when working around the collector, always standing downwind from the collector to prevent contaminants from the body and/or clothing of field personnel being transported into the funnel or collection bottle; and ensuring that the collector was not activated until the collection bottle containing the sample was removed. Field personnel indicated on the collection bottle the date and time the sample was removed.

The following procedures were used in securing the sampling equipment:

(1) the collector lid was opened, the funnel and tubing were removed, and the collector was wiped clean;
(2) a clean funnel and tubing were installed, and the collector lid was closed;

(3) once the collector had closed, a tared, clean, collection bottle was installed. Field personnel indicated on the bottle the date and time the collection bottle was installed;

(4) the rain-gage chart was removed from the Belfort rain gage, and the wet deposition collected in the rain gage was discarded. Field personnel indicated on the rain-gage chart the date and time the chart was removed;

(5) a new rain-gage chart was installed after field personnel indicated on the chart the date and time the chart was installed; and

(6) the rain gage was zeroed.

Field personnel also completed a field form indicating the date and time the sample was removed and the clean equipment was installed; the tare weight of every bottle; current weather conditions, and the maximum and minimum temperature measured inside the collector housing for the previous week were recorded.

The bottle containing the previous week's sample, funnel, tubing, rain-gage chart, and field form were sealed in a cooler with tape. The cooler was delivered to airport personnel, and an overnight mailing service was contacted. The cooler was shipped to the USGS office in Indianapolis, Ind.

After the cooler was received by personnel of the USGS office in Indianapolis, Ind., the following steps were used to process the sample before it was shipped to the USGS National Water Quality Laboratory (NWQL) in Arvada, Colo., for analyses:

(1) sample volume was determined; the sample in the collection bottle was weighed, and the tare weight of the bottle was subtracted from the weight of the bottle plus the sample; 
(2) $15 \mathrm{~mL}$ of the sample were removed and the $\mathrm{pH}$ was determined (this $\mathrm{pH}$ value will be referred to as the "field $\mathrm{pH}$ ");

(3) approximately $250 \mathrm{~mL}$ of the sample were filtered with a $47-\mathrm{mm} 0.45$ micrometer polycarbonate filter into a 250-mL high-density polyethylene bottle for laboratory determination of specific conductance and major anions;

(4) an additional $250-\mathrm{mL}$ aliquot was filtered into a $250-\mathrm{mL}$ glass bottle and preserved with $10 \mathrm{~mL}$ of a 1-percent potassium dichromate and nitric-acid solution for laboratory determination of mercury;

(5) the 5-L collection bottle then was reweighed, and the volume of the sample remaining was computed. The remaining sample was acidified with nitric acid to 2 percent by volume;

(6) the sample was shaken vigorously; $15 \mathrm{~mL}$ of the acidified sample were removed and the $\mathrm{pH}$ was measured. If the measured $\mathrm{pH}$ were greater than 2.0 , additional nitric acid was added and this step was repeated;

(7) the sample was allowed to stand for a minimum of 24 hours at $4^{\circ} \mathrm{C}$; and

(8) a $250-\mathrm{mL}$ aliquot of the acidified sample was filtered with a 47-mm, 0.45 -micrometer polycarbonate filter into a $250-\mathrm{mL}$ Teflon bottle for laboratory analysis of trace metals and major cations.

All sample handling performed at the USGS office in Indianapolis, Ind., was done on a laboratory bench top covered with Teflon. The bench top was covered with an adhesive-backed Teflon sheet to help minimize contamination during the preservation and filtering processes. The samples then were packed in ice and the cooler was sealed with tape and sent to the NWQL in Arvada, Colo., by overnight delivery service.
The NWQL required a minimum of $600 \mathrm{~mL}$ of sample for the analysis of major cations and anions, mercury, and the selected trace metals. Small-volume samples (less than $600 \mathrm{~mL}$ ) were not diluted to prevent the decreasing of some of the trace-metal concentrations below the method reporting limits. Therefore, a priority was established for analysis of small-volume samples. Weekly samples, with measured volumes smaller than $200 \mathrm{~mL}$, were analyzed only for field $\mathrm{pH}$. Samples with volumes between 200 and $400 \mathrm{~mL}$ were analyzed for field $\mathrm{pH}$ and trace metals (excluding mercury). Samples with volumes between 400 and $600 \mathrm{~mL}$ were analyzed for field $\mathrm{pH}$, trace metals (excluding mercury), and major cations and anions. Samples with measured volumes greater than $600 \mathrm{~mL}$ were analyzed for field $\mathrm{pH}$, specific conductance, trace metals, major cations and anions, and mercury. These priorities for analyses were adjusted occasionally to best utilize the volume collected.

\section{Water-Sample Analysis}

All samples were submitted to the Low Ionic Strength Section of the NWQL for analysis. Analytical techniques were chosen to provide the lowest reporting limits. Major cation (calcium, magnesium, sodium, and potassium) concentrations were determined by flame atomic absorption spectrometry (FAAS). FAAS provided the lowest reporting limit for major cations measured by the NWQL. If an insufficient sample volume were available for major cation concentrations to be determined by FAAS, and if sufficient volume were available for analysis by ICAP, the constituent concentrations reported by ICAP (except for potassium) are presented. Potassium concentrations were not reported by the NWQL when constituent concentrations for major cations were determined by ICAP. Major anions (sulfate, chloride, fluoride, bromide, nitrate, and phosphate) concentrations were determined by ion chromatography (IC). Arsenic was analyzed by atomic absorption spectrometry, hydride formation (HF). Silica, barium, beryllium, cadmium, chromium, cobalt, iron, 
lithium, molybdenum, nickel, silver, strontium, and vanadium were analyzed by ICAP. Cadmium, copper, lead, manganese, and zinc were analyzed by graphite furnace atomic absorption spectrometry (GFAAS); mercury was determined by atomic absorption spectrometry, cold vapor (CV). The method of analysis and method reporting limit for each of the constituents measured are listed in table 1.

\section{QUALITY OF WET DEPOSITION}

Fifty-eight weekly samples were collected during the 62-week sampling period (June 30, 1992-August 31, 1993). During 4 weeks, no wet deposition was collected in the collection bottle. Only 48 of the 58 samples were included in the analysis of data because of problems related to sample collection: 6 samples were lost as a result of the collector malfunctioning, 1 sample was lost in the mail, and 3 samples were lost because of gross contamination (bird droppings). During 3 of the other sampling weeks, the sample volume exceeded the volume of the collection bottle $(5 \mathrm{~L})$. Samples that overflowed the collection bottle were included in the analysis of the results.

Weekly wet-deposition amounts were measured from the continuous monitoring raingage charts and compared to the wet-deposition amounts computed from the measured volume of sample collected. Catch efficiencies were computed by dividing the wet-deposition amounts computed from the collected sample volume by the wet-deposition amounts measured from the rain-gage charts. Thirty-nine samples were used to compute the catch efficiencies; samples that overflowed the collection bottle were not used in the calculation. A median catch efficiency of 100.2 percent was computed. Because the catch efficiencies were close to 100 percent and because the Belfort rain gage was installed almost 1 month after the installation of the collector, wet-deposition amounts computed from the sample volume collected were used in determining loadings. Sample volumes computed from the wet-deposition amounts measured from the rain-gage charts were used in determining loadings for the three samples that overflowed the collection bottle. Figure 3 shows a truncated boxplot (Helsel and Hirsch, 1992) of the wet-deposition amounts.
Because the sample volumes varied during the study period, not all of the water-quality characteristics could be measured in small-volume samples. Of the 48 weekly samples collected, 25 samples were analyzed for all parameters (table 2); 5 samples were analyzed for all parameters (excluding mercury); 4 samples were analyzed for trace metals (excluding mercury), major cations (excluding potassium), and field $\mathrm{pH} ; 3$ samples were analyzed for trace metals (excluding mercury) and major cations (excluding potassium); 3 samples were analyzed for trace metals (including mercury), major cations (excluding potassium), and field pH; and 8 samples were analyzed for only field $\mathrm{pH}$ (table 6 , at back of report).

No results were reported greater than the method reporting limit for wet-deposition samples for arsenic, cobalt, mercury, molybdenum, nickel, and vanadium. Table 2 lists the characteristic measured; the number of times samples were measured for that characteristic; the number of times a value was measured greater than the method reporting limit; and the 25th, 50th, and 75 th percentile rankings.

Truncated boxplots of the measured concentrations determined for major ions collected at the Gary airport for all of the constituents that had more than 50 percent of the results reported as greater than the method reporting limit are shown in figure 4 . These results were compared to the weekly medians determined at the NADP sites located at the Indiana Dunes National Lakeshore and Huntington Reservoir. The Indiana Dunes National Lakeshore site is located approximately $26 \mathrm{~km}$ east of the Gary airport, and the Huntington Reservoir site is located approximately $180 \mathrm{~km}$ southeast of the Gary airport (fig. 5). Truncated boxplots comparing major ion concentrations measured from samples collected at the Gary airport with concentrations measured in samples collected at the Indiana Dunes National Lakeshore and Huntington Reservoir sites are shown in figure 6.

Calcium, magnesium, potassium, sulfate, chloride, and nitrate concentrations measured in samples collected at the Gary airport were similar to concentrations measured in samples collected at 
Table 1. Constituent, method of analysis, and the method reporting limits for the 29 constituents analyzed from samples collected at the Gary (Indiana) Regional Airport

[FAAS, flame atomic absorption spectrometry; ICAP, inductively coupled argon plasma atomic emission spectrometry; mg/L, milligrams per liter, IC, ion chromatography; HF, atomic absorption spectrometry, hydride formation; $\mu \mathrm{g} / \mathrm{L}$, micrograms per liter, GFAAS, graphite furnace atomic absorption spectrometry; $\mathrm{CV}$, atomic absorption spectrometry, cold vapor]

\begin{tabular}{|c|c|c|c|}
\hline Constituent & $\begin{array}{l}\text { Method of } \\
\text { analysis }\end{array}$ & $\begin{array}{c}\text { Method reporting } \\
\text { Ilmit }\end{array}$ & $\begin{array}{c}\text { Method reporting } \\
\text { units }\end{array}$ \\
\hline Calcium & FAAS/CAP & $0.01 / 0.02$ & $\mathrm{mg} / \mathrm{L}$ \\
\hline Magnesium & FAAS/ICAP & $.01 / .01$ & $\mathrm{mg} / \mathrm{L}$ \\
\hline Sodium & FAAS/ICAP & $.01 / .2$ & $\mathrm{mg} / \mathrm{L}$ \\
\hline Potassium & FAAS & .01 & $\mathrm{mg} / \mathrm{L}$ \\
\hline Sulfate & IC & .01 & $\mathrm{mg} / \mathrm{L}$ \\
\hline Chloride & IC & .01 & $\mathrm{mg} / \mathrm{L}$ \\
\hline Fluoride & IC & .01 & $\mathrm{mg} / \mathrm{L}$ \\
\hline Bromide & IC & .01 & $\mathrm{mg} / \mathrm{L}$ \\
\hline Silica & ICAP & .01 & $\mathrm{mg} / \mathrm{L}$ \\
\hline Nitrate & IC & .04 & $\mathrm{mg} / \mathrm{L}$ \\
\hline Phosphate & IC & .03 & $\mathrm{mg} / \mathrm{L}$ \\
\hline Arsenic & HF & 1 & $\mu \mathrm{g} / \mathrm{L}$ \\
\hline Barium & ICAP & 2 & $\mu \mathrm{g} / \mathrm{L}$ \\
\hline Beryllium & ICAP & .5 & $\mu \mathrm{g} / \mathrm{L}$ \\
\hline Cadmium & GFAAS & .1 & $\mu \mathrm{g} / \mathrm{L}$ \\
\hline Chromium & ICAP & 5 & $\mu \mathrm{g} / \mathrm{L}$ \\
\hline Cobalt & ICAP & 3 & $\mu \mathrm{g} / \mathrm{L}$ \\
\hline Copper & GFAAS & .5 & $\mu \mathrm{g} / \mathrm{L}$ \\
\hline Iron & ICAP & 3 & $\mu \mathrm{g} / \mathrm{L}$ \\
\hline Lead & GFAAS & .5 & $\mu \mathrm{g} / \mathrm{L}$ \\
\hline Lithium & ICAP & 4 & $\mu \mathrm{g} / \mathrm{L}$ \\
\hline Manganese & GFAAS & .2 & $\mu \mathrm{g} / \mathrm{L}$ \\
\hline Mercury & $\mathrm{CV}$ & .1 & $\mu \mathrm{g} / \mathrm{L}$ \\
\hline Molybdenum & ICAP & 10 & $\mu \mathrm{g} / \mathrm{L}$ \\
\hline Nickel & ICAP & 10 & $\mu \mathrm{g} / \mathrm{L}$ \\
\hline Silver & ICAP & 1 & $\mu \mathrm{g} / \mathrm{L}$ \\
\hline Strontium & ICAP & .5 & $\mu \mathrm{g} / \mathrm{L}$ \\
\hline Vanadium & ICAP & 6 & $\mu \mathrm{g} / \mathrm{L}$ \\
\hline Zinc & GFAAS & .5 & $\mu \mathrm{g} / \mathrm{L}$ \\
\hline
\end{tabular}




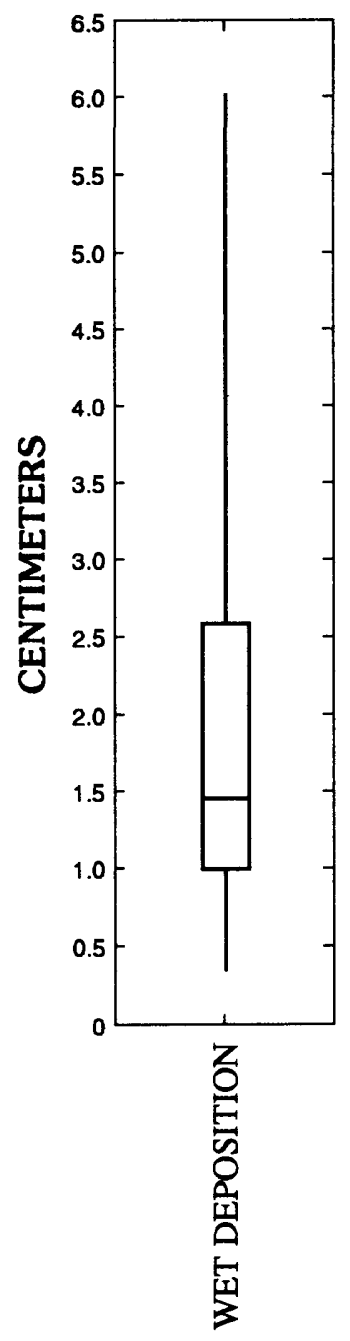

\section{EXPLANATION}

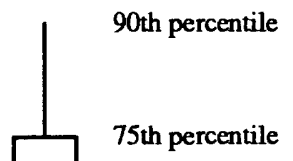

Median

25th percentile

10th percentile

Figure 3. Weekly wet-deposition amounts for the Gary (Indiana) Regional Airport. 
Table 2. Water-quality characteristic measured; number of samples measured for that characteristic; number of samples measured greater than the method reporting limit; and the 25th, 50th, and 75th percentile rankings for wet-deposition samples collected at the Gary (Indiana) Regional Airport

$[\mu \mathrm{S} / \mathrm{cm}$, microSiemens per centimeter at 25 degrees Celsius; NA, not applicable; $\mathrm{mg} / \mathrm{L}$, milligrams per liter, $<$, less than the method reporting limit; $\mu \mathrm{g} / \mathrm{L}$, micrograms per liter]

\begin{tabular}{|c|c|c|c|c|c|c|}
\hline \multirow{2}{*}{$\begin{array}{l}\text { Water-quality } \\
\text { characterlstlc }\end{array}$} & \multirow{2}{*}{$\begin{array}{c}\text { Number of } \\
\text { samples } \\
\text { measured }\end{array}$} & \multirow[t]{2}{*}{$\begin{array}{l}\text { Number of } \\
\text { samples } \\
\text { measured } \\
\text { greater than } \\
\text { the method } \\
\text { reporting limit }\end{array}$} & \multicolumn{3}{|c|}{ Percentlle ranking } & \multirow{2}{*}{$\begin{array}{c}\text { Method } \\
\text { reporting } \\
\text { unlts }\end{array}$} \\
\hline & & & 25th & 50th & 75th & \\
\hline Specific conductance & 30 & 30 & 18.8 & 21.8 & 31.0 & $\mu \mathrm{S} / \mathrm{cm}$ \\
\hline Field pH & 45 & NA & 4.23 & 4.48 & 4.79 & units \\
\hline Calcium & 40 & 40 & .26 & .74 & 1.50 & $\mathrm{mg} / \mathrm{L}$ \\
\hline Magnesium & 40 & 40 & .05 & .10 & .24 & $\mathrm{mg} / \mathrm{L}$ \\
\hline Sodium & 40 & 18 & $<.2$ & $<.2$ & .2 & $\mathrm{mg} / \mathrm{L}$ \\
\hline Potassium & 28 & 28 & .02 & .03 & .06 & $\mathrm{mg} / \mathrm{L}$ \\
\hline Sulfate & 30 & 30 & 2.1 & 2.9 & 4.3 & $\mathrm{mg} / \mathrm{L}$ \\
\hline Chloride & 30 & 30 & .13 & .24 & .39 & $\mathrm{mg} / \mathrm{L}$ \\
\hline Fluoride & 30 & 29 & .03 & .04 & .06 & $\mathrm{mg} / \mathrm{L}$ \\
\hline Bromide & 30 & 5 & $<.01$ & $<.01$ & $<.01$ & $\mathrm{mg} / \mathrm{L}$ \\
\hline Silica & 40 & 39 & .073 & .18 & .33 & $\mathrm{mg} / \mathrm{L}$ \\
\hline Nitrate & 30 & 30 & 1.44 & 1.73 & 3.10 & $\mathrm{mg} / \mathrm{L}$ \\
\hline Phosphate & 30 & 2 & $<.03$ & $<.03$ & $<.03$ & $\mathrm{mg} / \mathrm{L}$ \\
\hline Arsenic & 40 & 0 & $<1$ & $<1$ & $<1$ & $\mu \mathrm{g} / \mathrm{L}$ \\
\hline Barium & 40 & 32 & 2 & 3 & 4 & $\mu \mathrm{g} / \mathrm{L}$ \\
\hline Beryllium & 40 & 1 & $<.5$ & $<.5$ & $<.5$ & $\mu \mathrm{g} / \mathrm{L}$ \\
\hline Cadmium & 40 & 15 & $<.1$ & $<.1$ & .1 & $\mu \mathrm{g} / \mathrm{L}$ \\
\hline Chromium & 40 & 3 & $<5$ & $<5$ & $<5$ & $\mu \mathrm{g} / \mathrm{L}$ \\
\hline Cobalt & 40 & 0 & $<3$ & $<3$ & $<3$ & $\mu \mathrm{g} / \mathrm{L}$ \\
\hline Copper & 40 & 35 & .8 & 1.5 & 2.7 & $\mu \mathrm{g} / \mathrm{L}$ \\
\hline Iron & 40 & 40 & 13 & 24 & 56 & $\mu \mathrm{g} / \mathrm{L}$ \\
\hline Lead & 40 & 36 & .8 & 1.3 & 2.7 & $\mu \mathrm{g} / \mathrm{L}$ \\
\hline Lithium & 40 & 1 & $<4$ & $<4$ & $<4$ & $\mu \mathrm{g} / \mathrm{L}$ \\
\hline Manganese & 40 & 40 & 4.2 & 7.3 & 18.0 & $\mu \mathrm{g} / \mathrm{L}$ \\
\hline Molybdenum & 40 & 0 & $<10$ & $<10$ & $<10$ & $\mu \mathrm{g} / \mathrm{L}$ \\
\hline Mercury & 28 & 0 & $<.1$ & $<.1$ & $<.1$ & $\mu \mathrm{g} / \mathrm{L}$ \\
\hline Nickel & 40 & 0 & $<10$ & $<10$ & $<10$ & $\mu \mathrm{g} / \mathrm{L}$ \\
\hline Silver & 40 & 6 & $<1$ & $<1$ & $<1$ & $\mu \mathrm{g} / \mathrm{L}$ \\
\hline Strontium & 40 & 29 & $<.5$ & 1.0 & 3.0 & $\mu \mathrm{g} / \mathrm{L}$ \\
\hline Vanadium & 40 & 0 & $<6$ & $<6$ & $<6$ & $\mu \mathrm{g} / \mathrm{L}$ \\
\hline Zinc & 40 & 37 & 1.3 & 2.9 & 4.5 & $\mu \mathrm{g} / \mathrm{L}$ \\
\hline
\end{tabular}




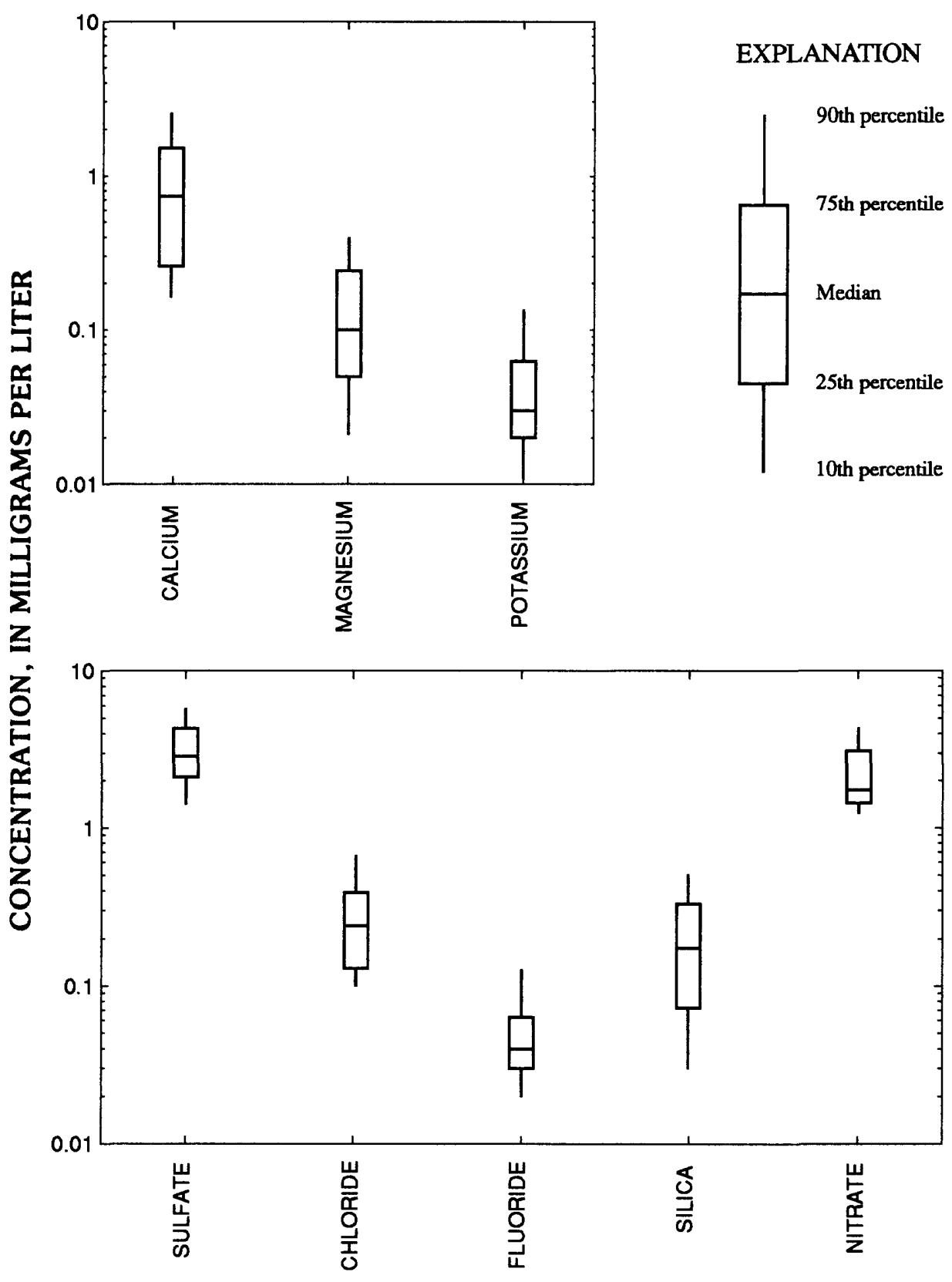

Figure 4. Constituent concentrations for major ions measured in wet-deposition samples collected at the Gary (Indiana) Regional Airport. 


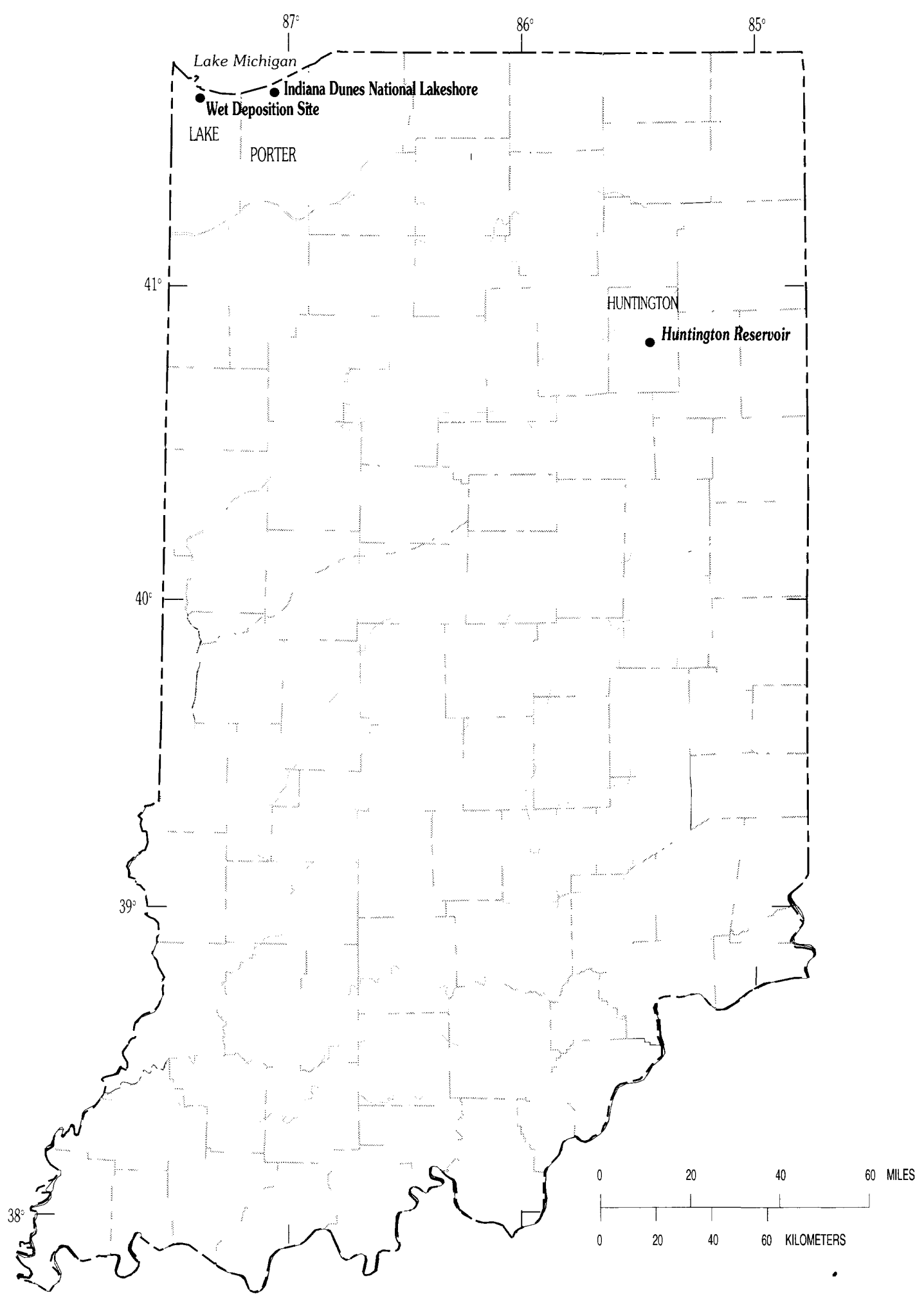

Base from U.S. Geological Survey. 1:100.000, 1983

Albers Equal-Area Conic projection

Standard parallels $29^{\circ} 30^{\prime}$ and $45^{\circ} 30^{\prime}$, central meridian $-86^{\circ}$

Figure 5. Location of wet-deposition site at the Gary (Indiana) Regional Airport and two National Atmospheric Deposition Program sampling sites at the Indiana Dunes National Lakeshore and Huntington Reservoir. 


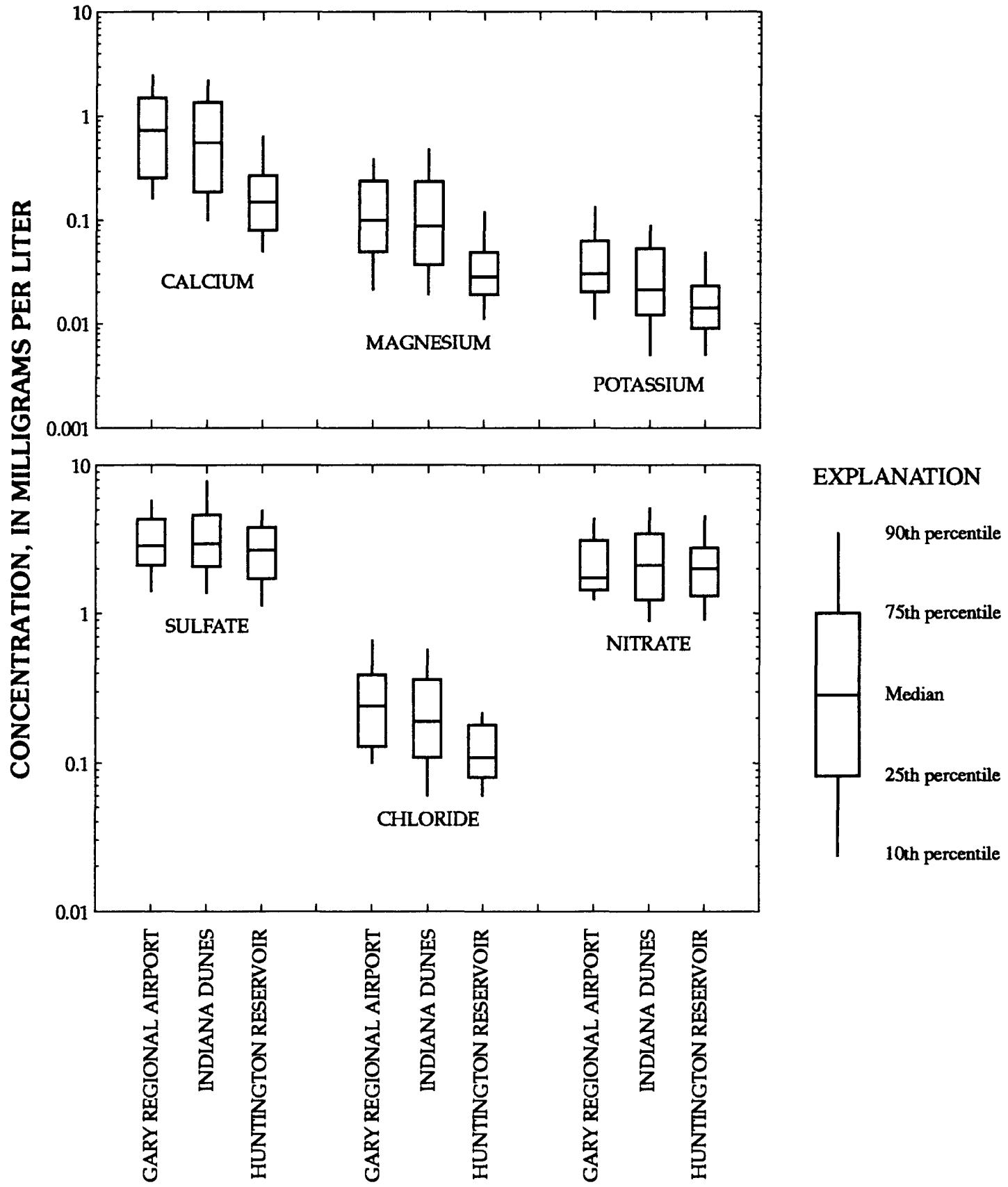

Figure 6. Major ion concentrations measured in samples collected at the Gary (Indiana) Regional Airport and two National Atmospheric Deposition Program sites located at the Indiana Dunes National Lakeshore and Huntington Reservoir. 
the Indiana Dunes National Lakeshore. Sulfate and nitrate concentrations measured in samples collected at the Gary airport also were similar to concentrations measured in samples collected at Huntington Reservoir. Calcium, magnesium, potassium, and chloride concentrations measured in samples collected at the Gary airport were generally larger than concentrations measured in samples collected at Huntington Reservoir. The similarity between the concentration distributions observed for samples collected at the Gary airport and for samples collected at the Indiana Dunes National Lakeshore is an indication that the sources affecting the chemistry of wet-deposition samples collected at the Gary airport may be the same sources affecting wet-deposition chemistry at the Indiana Dunes. It is possible that industrial processes in the Gary area are releasing contaminants to the atmosphere that are being transported, downwind, to the Indiana Dunes National Lakeshore site. Smaller concentrations measured in samples collected at the Huntington Reservoir site may indicate that contaminants being released to the atmosphere in the Gary area are not affecting the Huntington Reservoir site to the same extent as the Indiana Dunes National Lakeshore. Truncated boxplots of the measured concentrations for trace metals collected at the Gary airport for all of the constituents with more than 50 percent of the results reported greater than the method reporting limit are shown in figure 7. None of the median concentrations determined for major ions or trace metals at the Gary airport exceeded the U.S. Environmental Protection Agency guidelines for Maximum Contaminant Levels for drinking water (U.S. Environmental Protection Agency, 1992).

Median constituent concentrations were determined for samples collected during warm weather (April 1 through October 31) and during cold weather (November 1 through March 31). These median concentrations were substituted for missing values from samples collected during the same periods that had insufficient volumes for analysis of all the constituents listed in table 1.
The calculated weekly and annual loadings are, therefore, referred to as "estimated" values. If a measured constituent concentration were less than the method reporting limit, a range for that constituent's weekly loading was computed. To compute this range, zero was substituted for the constituent concentration (estimated minimum loading) and the method reporting limit was substituted for the constituent concentration (estimated maximum loading). A single value for the estimated weekly loading was calculated when the measured constituent concentration was greater than the method reporting limit. Estimated weekly major ion and trace-metal loadings are presented in figures 8 and 9 . Bars indicate that the measured sample was less than the method reporting limit and, therefore, a range for the weekly loading is presented.

An insufficient number of samples was collected at the Gary airport to perform a statistical seasonal trend analysis. A statistical trend analysis may be possible after a second year of sampling. Constituent concentrations appeared to be larger during times of the year when wet deposition was in the form of rain and not snow. The larger concentrations observed in rain are probably due to rain scavenging contaminants from the atmosphere more efficiently than snow.

The IDEM collects surface-water samples at six sites on the Grand Calumet River. Monthly samples collected from these sites could be used to assist in estimating the contribution that wet deposition has on the overall annual loadings from the Grand Calumet River. The USGS attempted to make this calculation by:

(1) estimating the drainage for the area of interest;

(2) calculating the discharge of the Grand Calumet River at the point farthest downstream in the drainage area; 


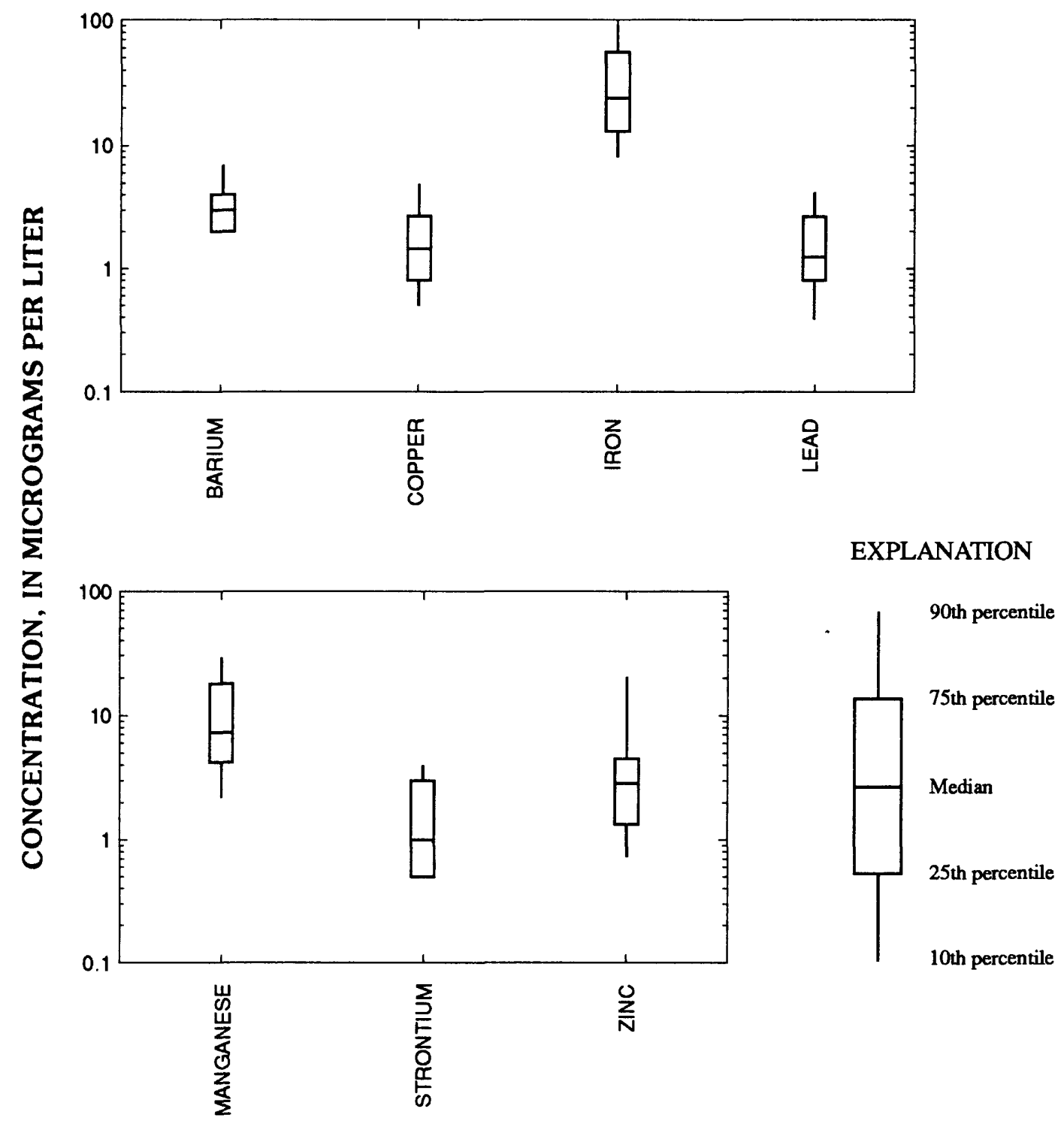

Figure 7. Constituent concentrations for trace metals measured in wet-deposition samples collected at the Gary (Indiana) Regional Airport. 

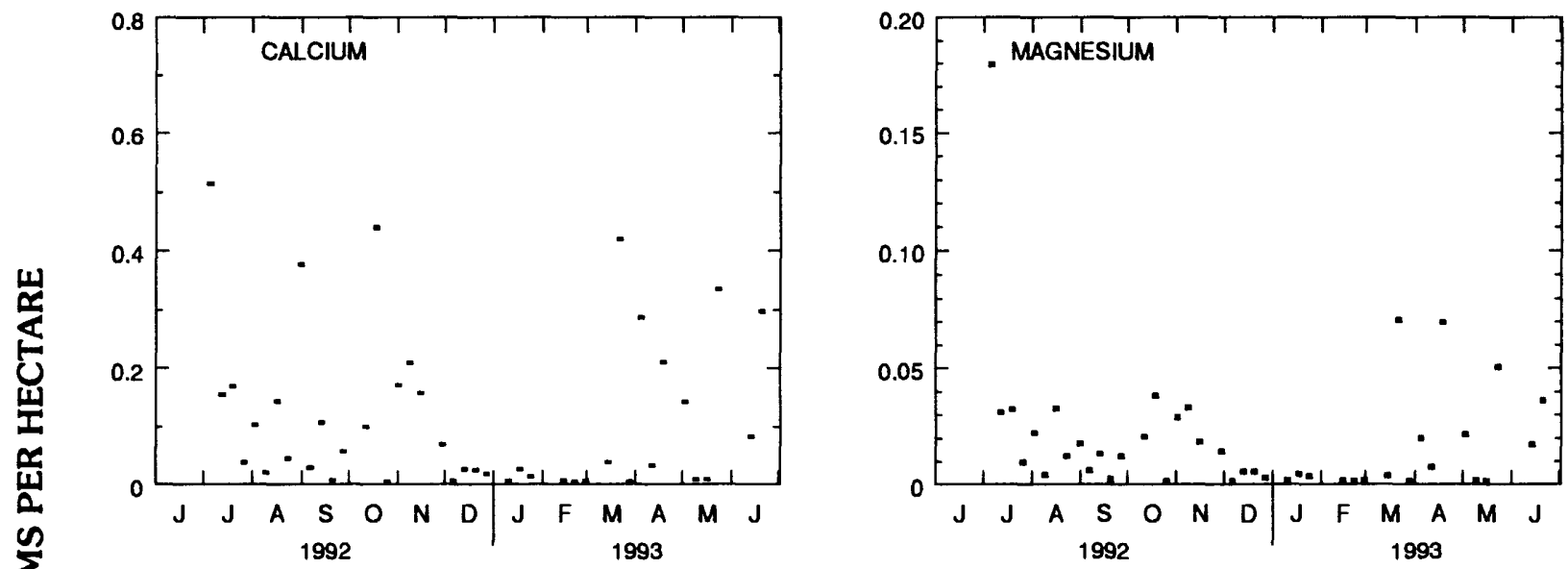

过
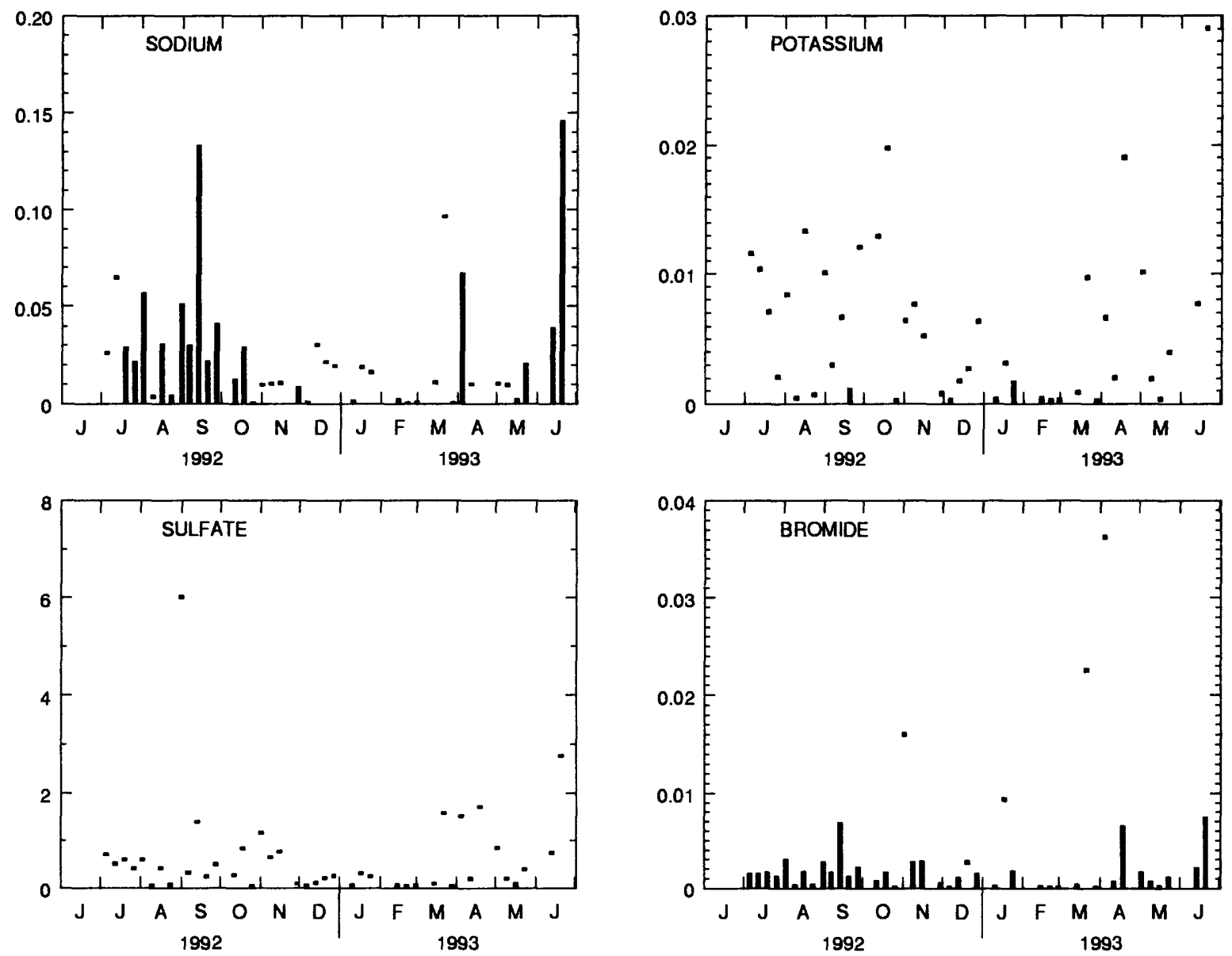

Figure 8. Estimated weekly major ion loadings determined from wet-deposition samples collected at the Gary (Indiana) Regional Airport. Bars indicate a possible range for the weekly loading and were computed when a measured constituent concentration was less than the method reporting limit.

The minimun value for a range is zero; the maximum value was computed by substituting the method reporting limit for the constituent concentration. 

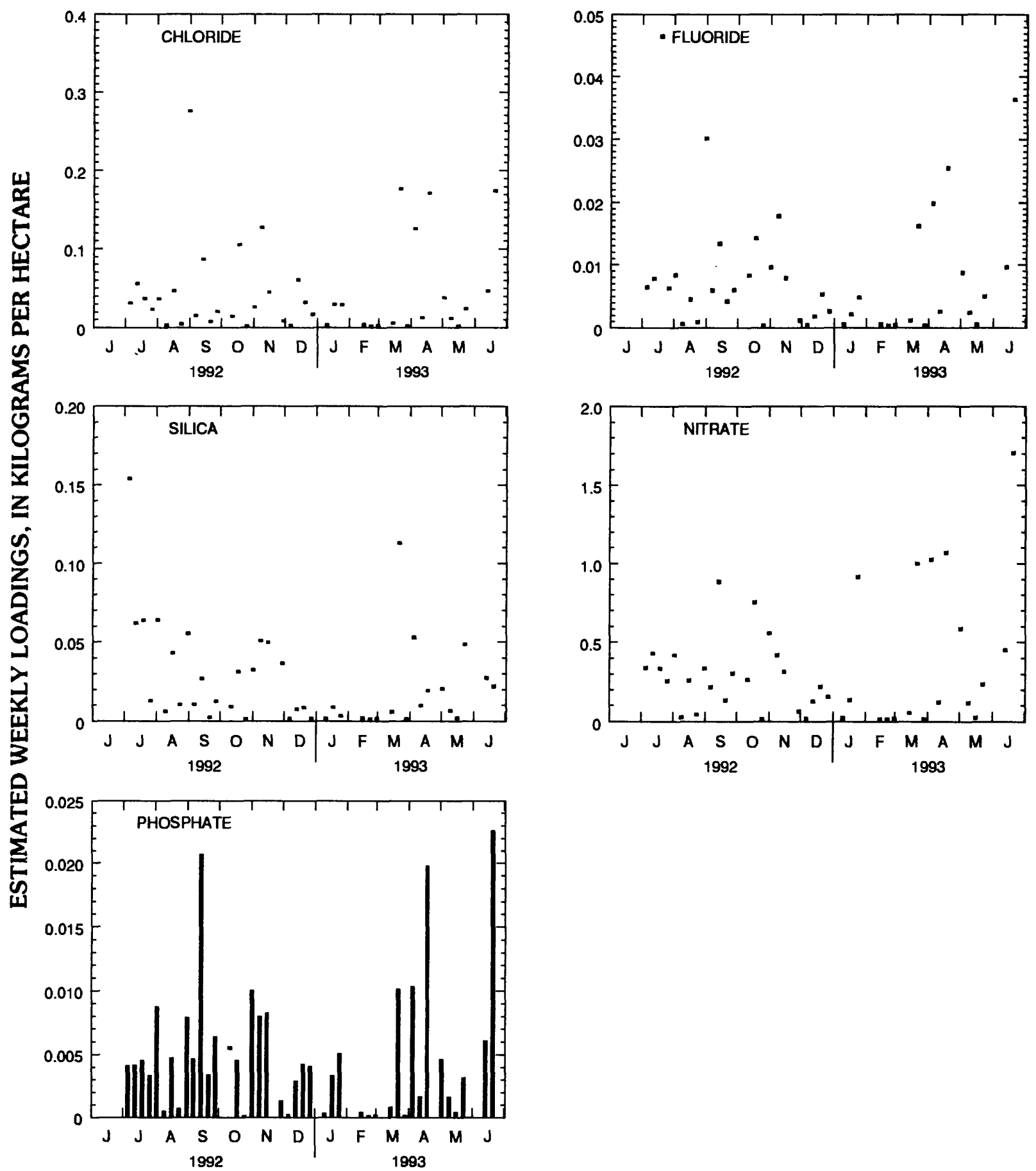

Figure 8. Estimated weekly major ion loadings determined from wet-deposition samples collected at the Gary (Indiana) Regional Airport--Continued. 

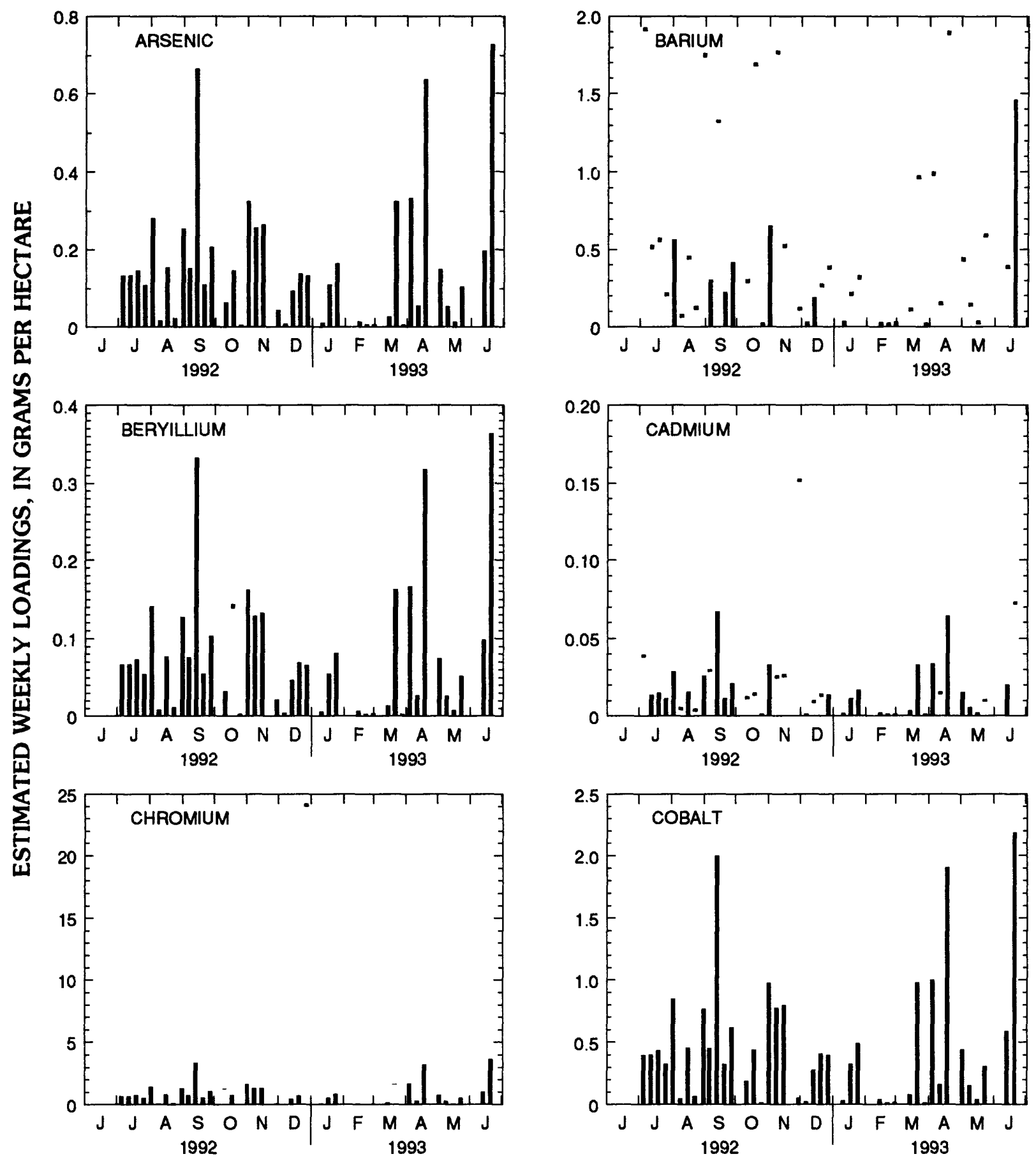

Figure 9. Estimated weekly trace-metal loadings determined from wet-deposition samples collected at the Gary (Indiana) Regional Airport. Bars indicate a possible range for the weekly loading and were computed when a measured constituent concentration was less than the method reporting limit. The minimun value for a range is zero; the maximum value was computed by substituting the method reporting limit for the constituent concentration. 

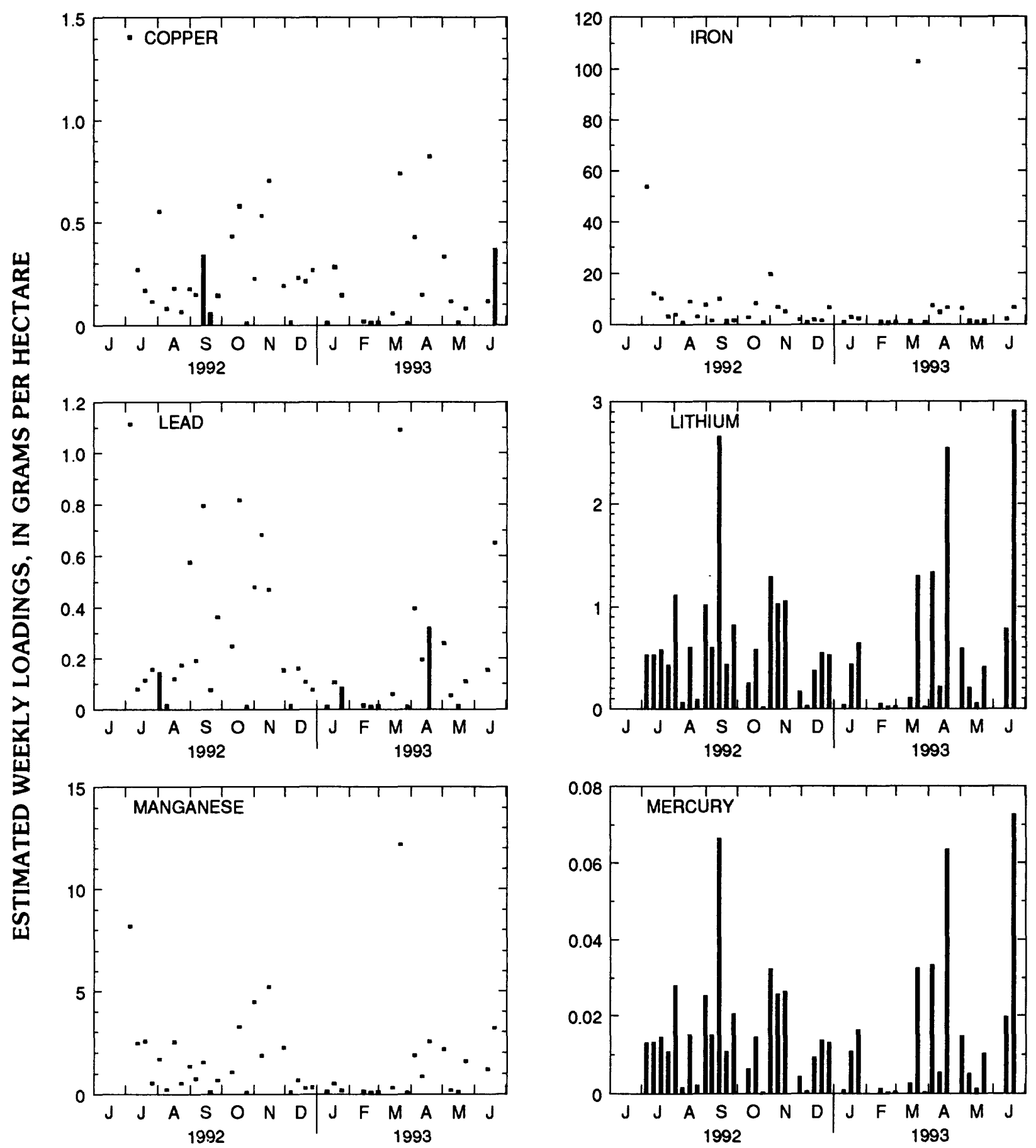

Figure 9. Estimated weekly trace-metal loadings determined from wet-deposition samples collected at the Gary (Indiana) Regional Airport--Continued. 

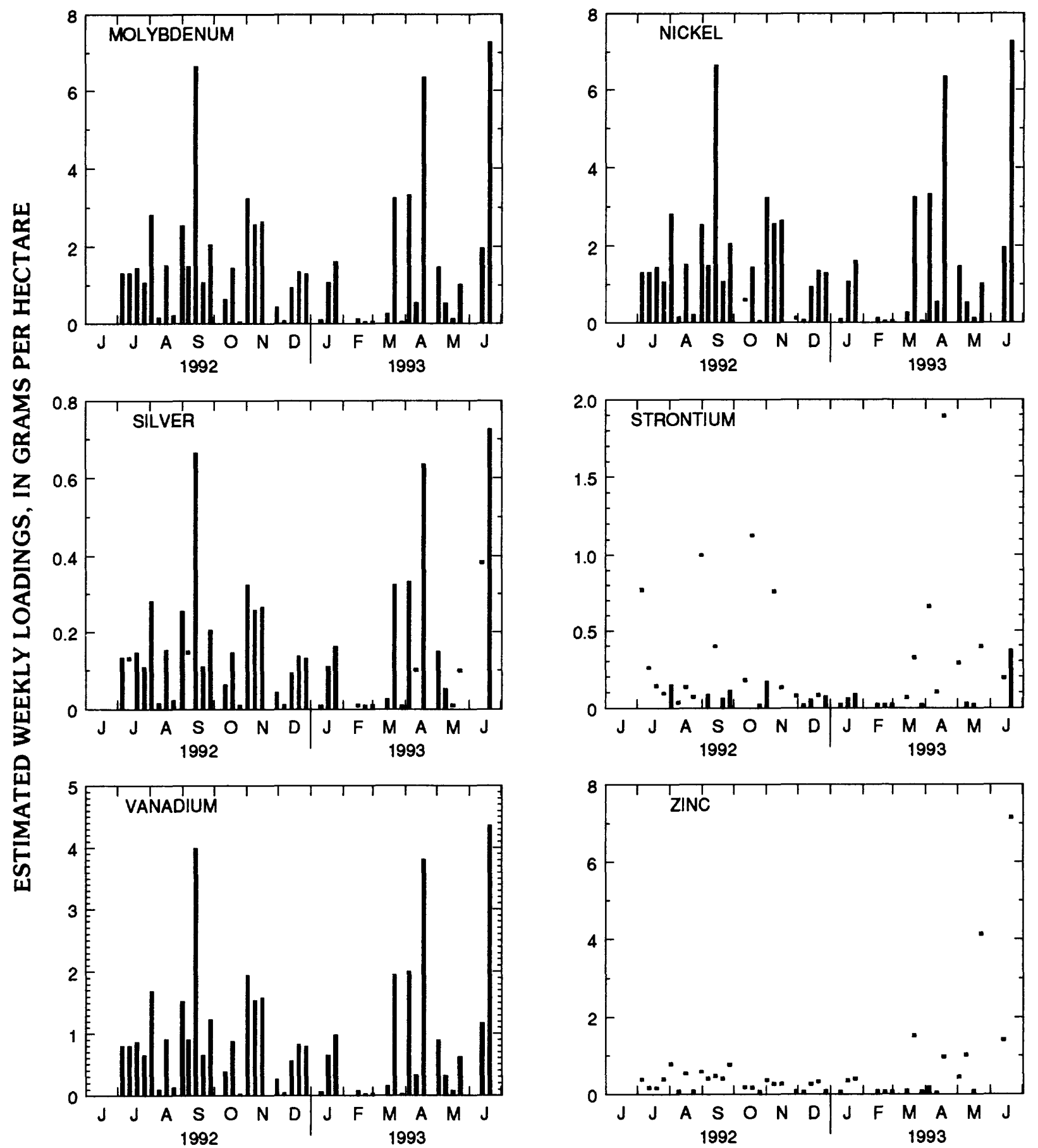

Figure 9. Estimated weekly trace-metal loadings determined from wet-deposition samples collected at the Gary (Indiana) Regional Airport--Continued. 
(3) using the discharge and the constituent concentrations from samples collected at the IDEM surface-water site located near the point where the discharge was determined to calculate the overall annual constituent loadings;

(4) using the drainage area and the concentrations measured for wetdeposition samples collected at the Gary airport to calculate the loadings to the Grand Calumet River from wet deposition; and

(5) computing the percent of the overall annual loading that is contributed by wet deposition.

A drainage area of 63.5 hectares for the Grand Calumet River upstream from Kennedy Avenue was calculated. This drainage area was calculated from USGS 1:24,000 scale maps (U.S. Geological Survey, $1991 \mathrm{a}, \mathrm{b}$ ). The drainage area, the six IDEM surface-water sites, and the wetdeposition collection site are shown in figure 10. It was beyond the scope of this project to determine the fate of wet deposition runoff in this drainage area that was redirected from the basin by sewers.

Discharge was measured at two sites on the Grand Calumet River; however, a stage-discharge relation could not be determined because of backwater affecting the discharge measurements (J.A. Stewart, U.S. Geological Survey, oral commun.). To alleviate the backwater problem, four ultrasonic velocity meters (UVM's) that measure the velocity of the Grand Calumet River at least once every hour were installed from 1992 through 1994. From the velocities measured by the UVM's, it would be possible to determine the stage-discharge relation; determining the stagedischarge relation would make it possible to estimate the overall loadings in the Grand Calumet River.
The range for the estimated annual constituent loadings (table 3) was calculated from the sum of the weekly loadings. Weekly loadings from 42 samples collected for 1 year beginning in June 30, 1992 , at the Gary airport were used to calculate the range for the estimated annual loadings. The minimum annual loading was calculated by summing the minimum weekly loadings, and the maximum annual loading was calculated by summing the maximum weekly loadings. If a single value were calculated for a weekly loading, that value was included in the calculations of the minimum and maximum annual loading. If all of the 42 values for a constituent were greater than the method reporting limit, a single value was calculated and is reported as the maximum and minimum estimated annual loading.

By determining the product of the drainage area (63.5 hectares) and the estimated minimum and maximum annual loadings, a range for the contribution wet deposition has on the overall loadings in the Grand Calumet River can be determined. It will not be possible to determine the contribution wet deposition has on the overall loadings in the Grand Calumet River until a stage-discharge relation is available.

\section{QUALITY ASSURANCE}

Because of the low analyte concentrations observed in wet deposition, 52 samples submitted to the NWQL during the study period were for quality control. Two types of quality-control samples were submitted. Laboratory qualitycontrol samples (table 7, at back of report) were submitted to evaluate the quality of the DIW used in preparing quality-control-check solutions and in cleaning the equipment, and to evaluate laboratory accuracy and precision. Field quality-control samples (table 8, at back of report) were used to evaluate possible contamination resulting from 


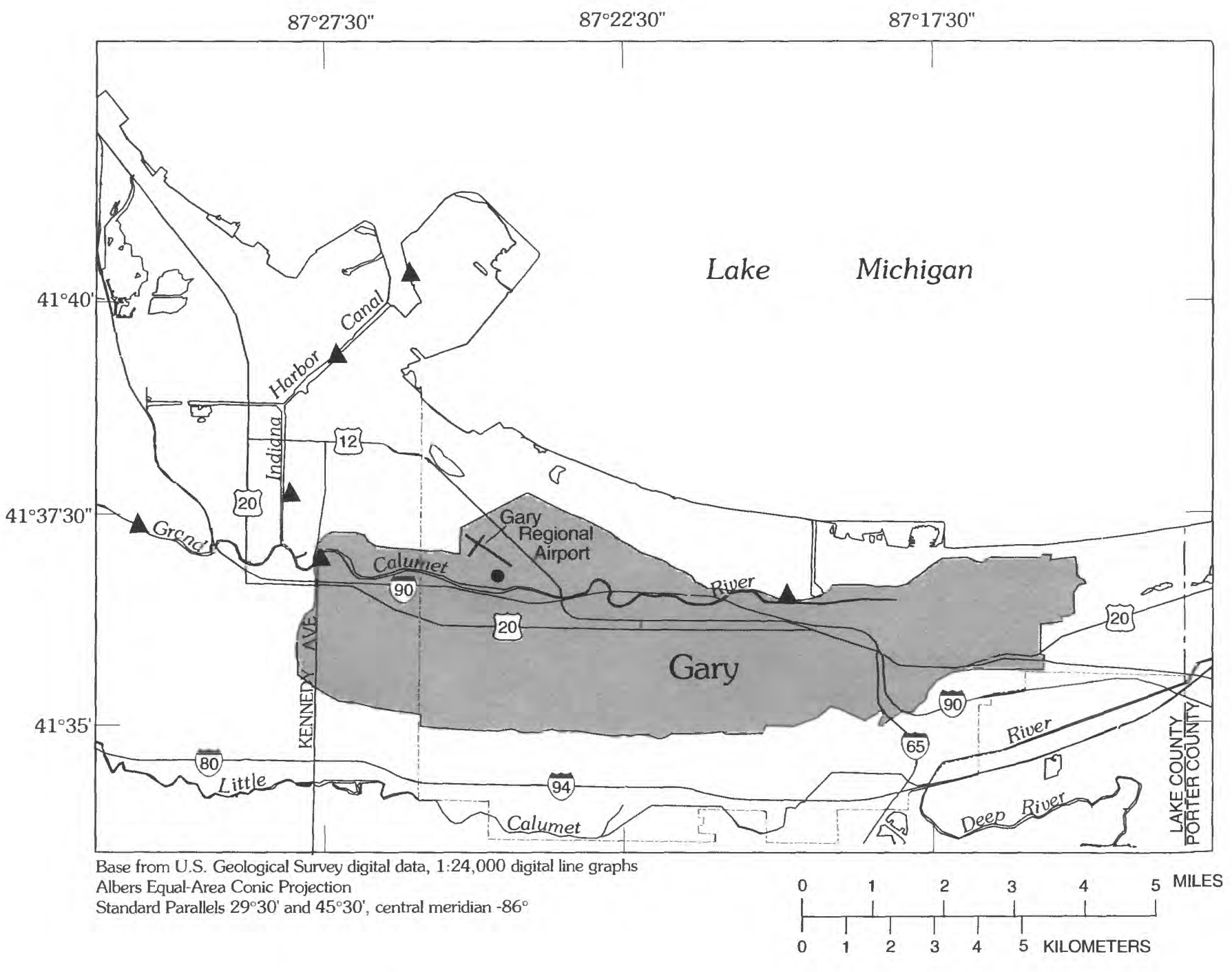

\section{EXPLANATION}

Drainage area

Gary city boundary

- U.S. Geological Survey wet-deposition sampling site

Indiana Department of Environmental
Management surface-water station

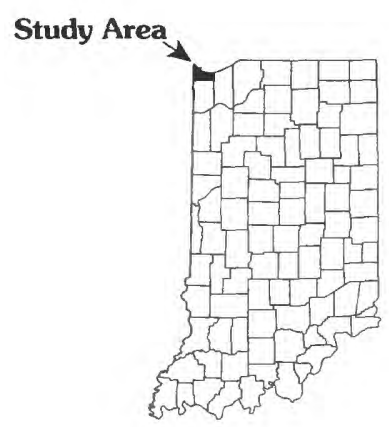

Figure 10. Location of drainage area for the Grand Calumet River upstream from Kennedy Avenue, Indiana Department of Environmental Management surface-water stations, and the wet-deposition sampling site at the Gary (Indiana) Regional Airport. 
Table 3. Range for the estimated annual loadings determined from wet-deposition samples collected at the Gary (Indiana) Regional Airport for 1 year beginning June 30, 1992

[kg/ha, kilograms per hectare; $\mathrm{g} / \mathrm{ha}$, grams per hectare]

\begin{tabular}{|c|c|c|c|}
\hline Constituent & $\begin{array}{l}\text { Estimated } \\
\text { minimum } \\
\text { annual loading }\end{array}$ & $\begin{array}{l}\text { Estimated } \\
\text { maximum } \\
\text { annual loading }\end{array}$ & $\begin{array}{l}\text { Reporting } \\
\text { units }\end{array}$ \\
\hline Calcium & 4.9 & 4.9 & $\mathrm{~kg} / \mathrm{ha}$ \\
\hline Magnesium & .85 & .85 & $\mathrm{~kg} / \mathrm{ha}$ \\
\hline Sodium & .36 & 1.2 & $\mathrm{~kg} / \mathrm{ha}$ \\
\hline Potassium & .24 & .25 & $\mathrm{~kg} / \mathrm{ha}$ \\
\hline Sulfate & 26 & 26.4 & $\mathrm{~kg} / \mathrm{ha}$ \\
\hline Bromide & .09 & .14 & $\mathrm{~kg} / \mathrm{ha}$ \\
\hline Chloride & 1.9 & 1.9 & $\mathrm{~kg} / \mathrm{ha}$ \\
\hline Fluoride & .34 & .34 & $\mathrm{~kg} / \mathrm{ha}$ \\
\hline Silica & 1.1 & 1.1 & $\mathrm{~kg} / \mathrm{ha}$ \\
\hline Nitrate & 14 & 14 & $\mathrm{~kg} / \mathrm{ha}$ \\
\hline Phosphate & .01 & .21 & $\mathrm{~kg} / \mathrm{ha}$ \\
\hline Arsenic & 0 & 6.6 & $\mathrm{~g} / \mathrm{ha}$ \\
\hline Barium & 18 & 21 & $\mathrm{~g} / \mathrm{ha}$ \\
\hline Beryllium & .14 & 3.4 & $\mathrm{~g} / \mathrm{ha}$ \\
\hline Cadmium & .42 & .86 & $\mathrm{~g} / \mathrm{ha}$ \\
\hline Chromium & 27 & 57 & $\mathrm{~g} / \mathrm{ha}$ \\
\hline Cobalt & 0 & 20 & $\mathrm{~g} / \mathrm{ha}$ \\
\hline Copper & 9.9 & 11 & $\mathrm{~g} / \mathrm{ha}$ \\
\hline Iron & 310 & 310 & $\mathrm{~g} / \mathrm{ha}$ \\
\hline Lead & 10 & 11 & $\mathrm{~g} / \mathrm{ha}$ \\
\hline Lithium & 0 & 26 & $\mathrm{~g} / \mathrm{ha}$ \\
\hline Manganese & 69 & 69 & $\mathrm{~g} / \mathrm{ha}$ \\
\hline Mercury & 0 & .66 & $\mathrm{~g} / \mathrm{ha}$ \\
\hline Molybdenum & 0 & 6.6 & $\mathrm{~g} / \mathrm{ha}$ \\
\hline Nickel & .70 & 6.5 & $\mathrm{~g} / \mathrm{ha}$ \\
\hline Silver & .88 & 6.8 & g/ha \\
\hline Strontium & 9.1 & 10 & $\mathrm{~g} / \mathrm{ha}$ \\
\hline Vanadium & 0 & 39 & g/ha \\
\hline Zinc & 24 & 24 & $\mathrm{~g} / \mathrm{ha}$ \\
\hline
\end{tabular}


cleaning, transporting, and installing the clean equipment in the collector, possible contamination from the funnel, tubing, and collection bottle installed in the collector at the sampling site for 1 week; and possible decreases in trace-metal concentrations resulting from trace metals absorbing onto the surfaces of the funnels, bottles, tubing, or filters. All sample processing procedures remained the same for field qualitycontrol samples, and all parameters and analytical techniques remained the same for the laboratory and field quality-control samples as those used for the wet-deposition samples.

\section{Laboratory Quallty Assurance}

Nine DIW blanks were submitted periodically during the length of the study to determine if there were any sources of contamination resulting from the water used to prepare solutions and clean the equipment. None of the constituents measured, except fluoride $(0.01 \mathrm{mg} / \mathrm{L})$, had median concentrations greater than the method reporting limit. The median concentration for fluoride in the DIW blanks was equal to the method reporting limit and is equivalent to 25 percent the median concentration determined in the wet-deposition samples (table 6, at back of report). The results for the DIW laboratory blanks indicate that no significant source of contamination was present in the DIW used for DIW funnel rinses, preparing acidified DIW funnel rinses, and cleaning the equipment.

Two U.S. Geological Survey standard reference water samples (SRWS) with reported concentrations also were submitted to the laboratory for analysis. These samples were used to evaluate laboratory accuracy and precision, and to evaluate the SRWS's used as field qualitycontrol samples.

To determine laboratory precision, 10 precipitation SRWS's (P17) prepared by the USGS SRWS Project were rebottled in the USGS office laboratory in Indianapolis, Ind., and submitted to the NWQL for analysis. Concentrations measured less than the method reporting limit were set equal to the method reporting limit. The 25 th, 50th, 75th percentile rankings and the calculated F-pseudosigmas (Hoaglin and others, 1983) for SRWS (P17) are listed in table 4. F-pseudosigma (eq. 1) is analogous to a standard deviation.

$$
F-p \text { seudosigma }=\frac{P 75-P 25}{1.349},
$$

where

$$
P 75 \text { is the 75th percentile; and }
$$

$P 25$ is the 25th percentile.

\section{F-pseudosigmas are presented in this report} because they are resistant to outliers. Laboratory precision for this report is defined as plus or minus the F-pseudosigmas computed for the SRWS (P17). Laboratory precision was within 10 percent of the median concentration determined for the wet-deposition samples collected at the Gary airport (table 6, at back of report) for all constituents except chloride ( 45 percent), fluoride (50 percent), silica (22 percent), and copper (40 percent).

\section{Fleld Quality Assurance}

DIW funnel rinses and acidified DIW funnel rinses were processed during the length of the study to evaluate the possible contamination resulting from cleaning the equipment, shipping the clean equipment to the Gary airport, installing the equipment in the collector, and processing the sample prior to sending it to the NWQL. DIW funnel rinses and acidified DIW funnel rinses were processed immediately after installation of clean equipment in the collector. The rinses were completed by passing $750 \mathrm{~mL}$ of the solution through the funnel, with as much of the inside of the funnel surface as possible exposed to the solution; the solution was collected in the collection bottle. The collection bottle was immediately removed and processed in the same manner as the wet-deposition samples. Median concentrations greater than the method 
Table 4. Constituent measured; 25 th, 50 th, and 75 th percentile rankings; and F-pseudosigmas for laboratory standard reference water sample (P17)

[mg/L, milligrams per liter, $<$, less than method reporting limit; NA, not applicable; $\mu \mathrm{g} / \mathrm{L}$, micrograms per liter]

\begin{tabular}{|c|c|c|c|c|c|}
\hline Constituent & 25th & $\frac{\text { entile } R \varepsilon}{50 \text { th }}$ & 75 th & F-pseudosigma & $\begin{array}{l}\text { Reporting } \\
\text { units }\end{array}$ \\
\hline Calcium & 0.31 & 0.32 & 0.32 & 0.01 & $\mathrm{mg} / \mathrm{L}$ \\
\hline Magnesium & .04 & .04 & .04 & 0 & $\mathrm{mg} / \mathrm{L}$ \\
\hline Sodium & .3 & .3 & .4 & .1 & $\mathrm{mg} / \mathrm{L}$ \\
\hline Potassium & .06 & .06 & .06 & 0 & $\mathrm{mg} / \mathrm{L}$ \\
\hline Sulfate & .5 & .5 & .6 & .1 & $\mathrm{mg} / \mathrm{L}$ \\
\hline Chloride & .39 & .45 & .57 & .13 & $\mathrm{mg} / \mathrm{L}$ \\
\hline Fluoride & $<.01$ & $<.01$ & .04 & .02 & $\mathrm{mg} / \mathrm{L}$ \\
\hline Bromide & $<.01$ & $<.01$ & $<.01$ & 0 & $\mathrm{mg} / \mathrm{L}$ \\
\hline Silica & .06 & .09 & .11 & .04 & $\mathrm{mg} / \mathrm{L}$ \\
\hline Nitrate & 1.19 & 1.20 & 1.25 & .04 & $\mathrm{mg} / \mathrm{L}$ \\
\hline Phosphate & $<.03$ & $<.03$ & $<.03$ & NA & $\mathrm{mg} / \mathrm{L}$ \\
\hline Arsenic & $<1$ & $<1$ & $<1$ & NA & $\mu \mathrm{g} / \mathrm{L}$ \\
\hline Barium & $<2$ & $<2$ & 2 & 0 & $\mu \mathrm{g} / \mathrm{L}$ \\
\hline Beryllium & $<.5$ & $<.5$ & $<.5$ & NA & $\mu \mathrm{g} / \mathrm{L}$ \\
\hline Cadmium & $<.1$ & .1 & .1 & 0 & $\mu \mathrm{g} / \mathrm{L}$ \\
\hline Chromium & $<5$ & $<5$ & $<5$ & NA & $\mu \mathrm{g} / \mathrm{L}$ \\
\hline Cobalt & $<3$ & $<3$ & $<3$ & NA & $\mu \mathrm{g} / \mathrm{L}$ \\
\hline Copper & .9 & 1.2 & 1.7 & .6 & $\mu \mathrm{g} / \mathrm{L}$ \\
\hline Iron & $<3$ & 3 & 4 & 0.7 & $\mu \mathrm{g} / \mathrm{L}$ \\
\hline Lead & $<.5$ & $<.5$ & $<.5$ & NA & $\mu \mathrm{g} / \mathrm{L}$ \\
\hline Lithium & $<4$ & $<4$ & $<4$ & NA & $\mu \mathrm{g} / \mathrm{L}$ \\
\hline Manganese & 9.2 & 9.4 & 9.9 & .5 & $\mu \mathrm{g} / \mathrm{L}$ \\
\hline Molybdenum & $<10$ & $<10$ & $<10$ & NA & $\mu \mathrm{g} / \mathrm{L}$ \\
\hline Nickel & $<10$ & $<10$ & $<10$ & NA & $\mu \mathrm{g} / \mathrm{L}$ \\
\hline Silver & $<1$ & 1 & 2 & 1 & $\mu \mathrm{g} / \mathrm{L}$ \\
\hline Strontium & 2 & 2 & 2 & 0 & $\mu \mathrm{g} / \mathrm{L}$ \\
\hline Vanadium & $<6$ & $<6$ & $<6$ & NA & $\mu \mathrm{g} / \mathrm{L}$ \\
\hline Zinc & 9.8 & 10 & 10 & .1 & $\mu \mathrm{g} / \mathrm{L}$ \\
\hline
\end{tabular}


reporting limit were determined from aliquots of the DIW funnel rinses for sulfate $(0.01 \mathrm{mg} / \mathrm{L})$, fluoride $(0.02 \mathrm{mg} / \mathrm{L})$, silica $(0.04 \mathrm{mg} / \mathrm{L})$, nitrate $(0.13 \mathrm{mg} / \mathrm{L})$, and manganese $(0.3 \mu \mathrm{g} / \mathrm{L})$. All of these median concentrations (except for fluoride and silica) were below 10 percent of the median concentrations determined for the wet-deposition samples (fig. 11). The median concentrations determined for the DIW funnel rinses were 50 percent of the median concentration determined in the wet-deposition samples for fluoride; however, the median concentration determined for fluoride in the wet-deposition samples $(0.04 \mathrm{mg} / \mathrm{L})$ was low (4 times the method reporting limit). The median concentration determined for the DIW funnel rinses was 22 percent of the median concentration determined in the wet-deposition samples for silica.

The results determined from the DIW funnel rinses indicate that contamination resulting from cleaning the equipment, shipping the clean equipment to the Gary airport, installing the equipment in the collector, and processing the samples did not result in significant contamination when compared to the concentrations measured in the wet-deposition samples. The median concentration of $0.13 \mathrm{mg} / \mathrm{L}$ determined for nitrate (fig. 10) in the DIW funnel rinses was probably a result of crossover contamination from the large quantity of nitric acid used during this study to clean the equipment and preserve the samples.

Because the median $\mathrm{pH}$ reported for wetdeposition samples collected at the NADP Indiana Dunes National Lakeshore site was approximately 4.5, acidified DIW funnel rinses also were processed. The acidified DIW funnel rinses were prepared by diluting Ultrex nitric acid to a target $\mathrm{pH}$ of 4.5 with DIW.

Seven 750-mL acidified DIW funnel rinses were processed during the length of the study and median concentrations were computed; nitrate was excluded because nitric acid was used in the preparation of the acidified DIW funnel rinses. Median concentrations greater than the method reporting limit were determined for silica $(0.04 \mathrm{mg} / \mathrm{L})$, copper $(0.6 \mu \mathrm{g} / \mathrm{L})$, manganese $(0.6 \mu \mathrm{g} / \mathrm{L})$, and zinc $(1 \mu \mathrm{g} / \mathrm{L})$. The median concentration measured for the acidified DIW funnel rinses was 40 percent for copper and 22 percent for silica and zinc of the median weekly concentration computed for the wet-deposition samples (fig. 10). The median concentration measured for the acidified DIW funnel rinses for manganese was less than 10 percent the median weekly concentration measured for the wet-deposition samples.

To examine if the constituent concentrations were altered by the funnel, Teflon tubing, Teflon collection bottle, or sample filtering, SRWS's (T117) were processed in the same manner as the DIW and acidified DIW funnel rinses. Not all of the constituents were present in sufficient concentrations for all of the constituents of interest to be compared; however, some constituent comparisons were possible. Five samples of the same matrix (SRWS T117) were rebottled in the USGS office laboratory in Indianapolis, Ind., and submitted to the NWQL for analysis. These samples will be referred to as "SRWS (T117) funnel rinses." Five SRWS's (T117) were processed as funnel rinses. The constituent, median concentrations computed for the SRWS (T117) funnel rinses, median concentrations computed for the laboratory SRWS's (T117), the reported concentrations and F-pseudosigmas for SRWS (T117) (Keith Long, U.S. Geological Survey, written commun.) are listed in table 5 .

All of the median concentrations determined for the SRWS (T117) funnel rinses (except for the median concentrations determined for zinc) were within the reported median concentrations plus or minus the reported F-pseudosigmas. All of the median concentrations determined for the laboratory SRWS's (T117) (except for the median concentrations determined for cobalt, strontium, and zinc) were within the reported median concentrations plus or minus the F-pseudosigmas. 


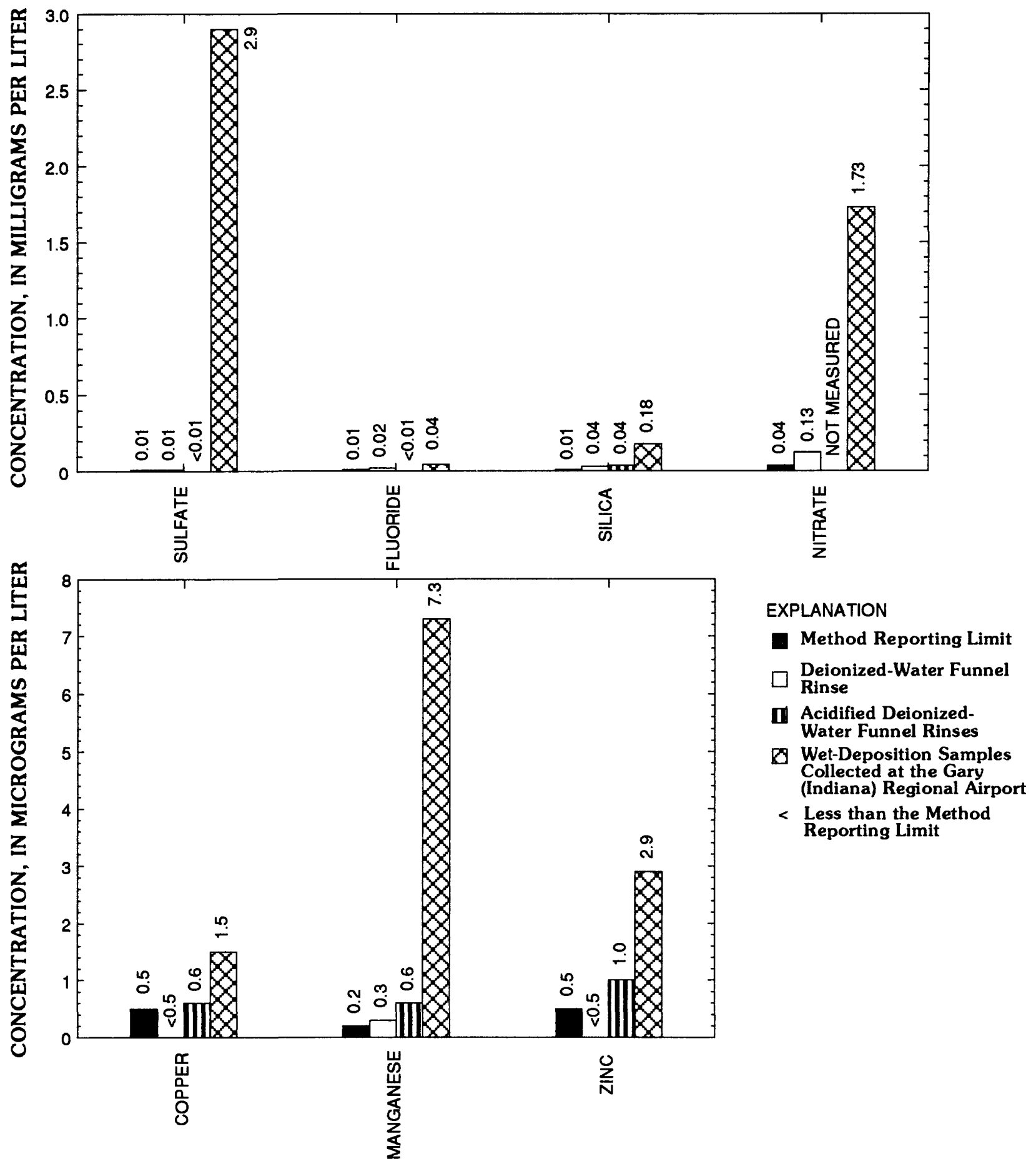

Figure 11. Median constituent concentrations computed for the deionized-water funnel rinses and the acidified deionized-water funnel rinses compared to the median constituent concentrations computed for the wet-deposition samples and the method reporting limit. 
Table 5. Comparison among median concentrations for the standard reference water sample (T117) funnel rinse processed at the Gary (Indiana) Regional Airport, median concentrations for the laboratory standard reference water sample (T117), and reported concentrations and F-pseudosigmas for standard reference water sample (T117)

[SRWS; U.S. Geological Survey standard reference water sample; $\mathrm{mg} / \mathrm{L}$, milligrams per liter, $\mu \mathrm{g} / \mathrm{L}$, micrograms per liter; $<$, reported less than the method reporting limit]

\begin{tabular}{|c|c|c|c|c|c|}
\hline Constituent & $\begin{array}{c}\text { Median } \\
\text { concentration for } \\
\text { SRWS (T117) } \\
\text { funnel rinses }\end{array}$ & $\begin{array}{l}\text { Median } \\
\text { concentration } \\
\text { for laboratory } \\
\text { SRWS (T117) }\end{array}$ & $\begin{array}{l}\text { SRWS } \\
\text { (T117) reported } \\
\text { concentration }\end{array}$ & $\begin{array}{c}\text { SRWS } \\
\text { (T117) reported } \\
\text { F-pseudosigma }\end{array}$ & $\begin{array}{c}\text { Reporting } \\
\text { unit }\end{array}$ \\
\hline Calcium & 22.0 & 22.0 & 20.9 & 1.2 & $\mathrm{mg} / \mathrm{L}$ \\
\hline Magnesium & 10.0 & 10.0 & 10.1 & .4 & $\mathrm{mg} / \mathrm{L}$ \\
\hline Sodium & 20.0 & 19.0 & 20.0 & 1.3 & $\mathrm{mg} / \mathrm{L}$ \\
\hline Silica & 12.0 & 12.0 & 11.85 & .64 & $\mathrm{mg} / \mathrm{L}$ \\
\hline Arsenic & 7.0 & 8.0 & 6.9 & 1.4 & $\mu \mathrm{g} / \mathrm{L}$ \\
\hline Barium & 97 & 97 & 98 & 6 & $\mu \mathrm{g} / \mathrm{L}$ \\
\hline Beryllium & 4.9 & 4.9 & 4.8 & .4 & $\mu \mathrm{g} / \mathrm{L}$ \\
\hline Cadmium & 2.6 & 2.5 & 2.2 & .4 & $\mu \mathrm{g} / \mathrm{L}$ \\
\hline Chromium & 10 & 9 & 10 & 2 & $\mu \mathrm{g} / \mathrm{L}$ \\
\hline Cobalt & 4 & $<3$ & 4.3 & .7 & $\mu \mathrm{g} / \mathrm{L}$ \\
\hline Copper & 6.5 & 5.6 & 6.0 & 1.8 & $\mu \mathrm{g} / \mathrm{L}$ \\
\hline Iron & 480 & 480 & 474 & 18 & $\mu \mathrm{g} / \mathrm{L}$ \\
\hline Lead & 5.5 & 5.1 & 5.0 & 1.3 & $\mu \mathrm{g} / \mathrm{L}$ \\
\hline Lithium & 21 & 22 & 20 & 3 & $\mu \mathrm{g} / \mathrm{L}$ \\
\hline Manganese & 21 & 20 & 22 & 3 & $\mu \mathrm{g} / \mathrm{L}$ \\
\hline Molybdenum & 10 & $<10$ & 12 & 2 & $\mu \mathrm{g} / \mathrm{L}$ \\
\hline Nickel & $<10$ & $<10$ & 10 & 2 & $\mu \mathrm{g} / \mathrm{L}$ \\
\hline Silver & $<1$ & $<1$ & 1.4 & 6.4 & $\mu \mathrm{g} / \mathrm{L}$ \\
\hline Strontium & 270 & 280 & 265 & 11 & $\mu \mathrm{g} / \mathrm{L}$ \\
\hline Vanadium & $<6$ & $<6$ & 4.7 & 1.8 & $\mu \mathrm{g} / \mathrm{L}$ \\
\hline Zinc & 59 & 190 & 176 & 9 & $\mu \mathrm{g} / \mathrm{L}$ \\
\hline
\end{tabular}


The median strontium concentration measured for the SRWS (T117) funnel rinses and the laboratory SRWS's (T117) were within 10 percent of the reported concentration. The median cobalt concentration determined for the laboratory SRWS's (T117) was less than the method reporting limit of $3 \mu \mathrm{g} / \mathrm{L}$, which is at least 30 percent lower than the reported concentration. None of the wetdeposition samples collected at the Gary airport had measured concentration greater than the method reporting limit for cobalt, indicating no significant cobalt contamination from the funnel, Teflon tubing, Teflon collection bottle, or filtering of the wet-deposition samples. The measured zinc concentrations determined for the five SRWS (T117) funnel rinses ranged from $5.3 \mu \mathrm{g} / \mathrm{L}$ to $490 \mu \mathrm{g} / \mathrm{L}$ when analyzed by GAFFS (table 8 ). In addition, the median concentration determined for the laboratory SRWS's (T117) was 8 percent larger than the reported concentration. This scatter in the zinc results was not observed in the wetdeposition samples (less than 0.5 to $42 \mu \mathrm{g} / \mathrm{L}$ ) or in any of the DIW or acidified DIW funnel rinses and is probably not an indication that there was a contamination problem with the wet-deposition samples. In addition, zinc also was analyzed by ICAP; however, zinc concentrations determined by ICAP are not presented because the method reporting limit was greater than most of the concentrations observed in the wet-deposition samples. On review of the ICAP results for zinc, the median concentration reported was $190 \mu \mathrm{g} / \mathrm{L}$, which is equivalent to the median concentration determined for the laboratory SRWS's (T117) (table 4). The median concentration determined for the laboratory SRWS's (T117) for zinc was also within 10 percent of the reported concentration.

To evaluate possible contamination resulting from the equipment remaining on the sampler for 1 week, four system blanks were processed on weeks when no wet deposition was collected in the collection bottle. System blanks were processed in the same manner as funnel rinses, except they were done at the end of the sampling week before installation of clean equipment in the collector. Median concentrations were computed for the system blanks (table 8). Of the constituents measured, calcium $(0.045 \mathrm{mg} / \mathrm{L})$, magnesium $(0.005 \mathrm{mg} / \mathrm{L})$, potassium $(0.03 \mathrm{mg} / \mathrm{L})$, sulfate $(0.035 \mathrm{mg} / \mathrm{L})$, chloride $(0.025 \mathrm{mg} / \mathrm{L})$, fluoride $(0.07 \mathrm{mg} / \mathrm{L})$, silica $(0.04 \mathrm{mg} / \mathrm{L})$, manganese $(0.9 \mu \mathrm{g} / \mathrm{L})$, and zinc $(0.65 \mu \mathrm{g} / \mathrm{L})$ had median concentrations greater than the method reporting limit. These concentrations were equal to or greater than the median concentrations determined for the DIW funnel rinses and acidified DIW funnel rinses, indicating that contamination of the wet-deposition samples increased during the period the funnel, Teflon tubing, and Teflon collection bottle remained in the collector.

\section{SUMMARY}

Modifications were made to an AeroChem Metric 301 wet/dry collector for the collection and analysis of wet-deposition samples to evaluate the effects wet deposition may have on the chemical quality of the Grand Calumet River watershed and Lake Michigan. Wet-deposition samples were collected at the Gary (Indiana) Regional Airport from June 30, 1992, through August 31, 1993, and analyzed for $\mathrm{pH}$, specific conductance, and selected major ions and trace metals. Fortyeight samples were collected over the 62-week study with sufficient volumes for some or all of the parameters to be measured. None of the samples collected at the Gary airport had measured concentrations greater than the method reporting limit for arsenic, cobalt, mercury, molybdenum, nickel, and vanadium. Sample concentrations measured at the Gary airport for calcium, magnesium, potassium, sulfate, and chloride, were similar to concentrations measured at the NADP site located at the Indiana Dunes National Lakeshore but larger than concentrations measured at the NADP site located at Huntington Reservoir. The Indiana Dunes National Lakeshore site is located approximately $26 \mathrm{~km}$ east and the Hunnington Reservoir is located approximately $180 \mathrm{~km}$ southeast of the Gary airport. 
Similar concentrations were measured for major ions at the Indiana Dunes National Lakeshore, compared to samples collected at the Gary airport. This may indicate that the sources affecting samples collected at the Gary airport are the same sources affecting samples collected at the Indiana Dunes National Lakeshore.

A drainage area was estimated, not taking into account redirection of storm runoff, for a part of the Grand Calumet River. Ranges for weekly and annual loadings were calculated from the measured concentrations for samples collected at the Gary airport to estimate the contribution wet deposition has on the overall loadings in the Grand Calumet River. The calculation of the streamflow loadings was not possible for this study because a stage-discharge relation was not available for the Grand Calumet River. The USGS has installed UVM's to measure the velocity of the Grand Calumet River and determine a stage-discharge relation. This calculation may be possible following an additional year of sampling.

An insufficient number of samples was collected at the Gary airport to perform a seasonal trend analysis; however, sample concentrations from weeks when rain was the predominant form of wet deposition were larger than for weeks when snow was predominant. Concentrations measured in samples collected from rain events were probably larger than concentrations measured in samples from snow events because of better scavenging of the atmosphere by rain.

In addition to the wet-deposition samples collected at the Gary airport, 52 quality-assurance samples were submitted for analysis to determine if the cleaning, transporting, installing, or filtering of the samples contributed contamination to the samples. Quality-control samples also were submitted to examine the accuracy of analytical procedures used by the NWQL for this study. Some problems associated with contamination in the field and possibly with the analyses for zinc were observed; however, these problems did not appear to affect substantially the wet-deposition samples.

Northwestern Indiana is the State's highest priority area for nonpoint-source pollution control. The impact of airborne pollutants in this industrialized area may have a major effect on the chemical quality on inland waters and Lake Michigan. More wet-deposition data are needed to evaluate the transport of airborne pollutants and to determine the contribution that wet deposition has on the overall loadings in the Grand Calumet River. 


\section{REFERENCES CITED}

Amdur, M.O.; Doull, John; and Klaassen, C.D., eds., 1993, Casarett and Doull's toxicology, the basic science of poisons (4th ed.): New York, McGrawHill, p. 623-680.

Bigelow, D.S., 1984, Instruction manual-NADP/NTN site selection and installation: National Atmospheric Deposition Program, National Resources Ecology Laboratory, Colorado State University, Fort Collins, Colo., 23 p.

Bigelow, D.S., and Dossett, S.R., 1988, instruction manual-NADP/NTN site operation: National Atmospheric Deposition Program, National Resources Ecology Laboratory, Colorado State University, Fort Collins, Colo., $40 \mathrm{p}$.

Dossett, S.R., and Bowersox, V.C., 1991, The potential for sample contamination due to raindrop splash off of the NADP wet/dry precipitation collector, in NADP Technical Committee Meeting, Proceedings: Philadelphia, Pa., October 7-10, 1991, National Atmospheric Deposition Program, p. 6.

Eisler, Ronald, 1988, Arsenic hazards to fish, wildlife, and invertebrates-a synoptic review: U.S. Fish and Wildlife Service Biological Report 85(1.12), 92 p.

Fishman, M.J., and Friedman, L.C., eds., 1989, Methods for determination of inorganic substances in water and fluvial sediments (3d ed.): U.S. Geological Survey Techniques of Water-Resources Investigations, book 5, chap. A1, $545 \mathrm{p}$.

Fogg, T.R., and Fitzgerald, W.F., 1979, Mercury in southern New England coastal rain: Journal of Geophysical Research, v. 84, no. c11, p. 6987-6989.

Galloway, J.N.; Cowling, E.B.; Gorham, Eville; and McFee, W.W., 1978, A national program for assessing the problem of atmospheric deposition (acid rain)-National Atmospheric Deposition Program report to the U.S. Council on Environmental Quality: Washington, D.C., 94 p.
Herdendorf, C.E., 1982, Large lakes of the world: Journal of Great Lakes Research, v. 8, no. 3, p. 379-412.

Helsel, D.R., and Hirsch, R.M., 1992, Statistical method in water resources, studies in environmental science 49: Elsevier Science Publishing Co. Inc., New York, p. 26.

Hoaglin, D.C.; Mosteller, F.; and Tukey, J.W., 1983, Understanding robust and exploratory data analysis, John Wiley \& Sons, Inc., New York, NY, p. 40.

Indiana Nonpoint Source Task Force, 1989, Indiana Nonpoint Source Water Pollution Management Program, p. 68, 98.

Klappenbach, E.W., 1991, Analysis and deposition of trace metals around the Great Lakes, in The deposition and fate of trace metals in our environment, Philadelphia, October 1991, Proceedings: USDAForest Service, North Central Forest Experimental Station, p. 37-43.

Schroder, L.J., and Hedley, A.G., 1986, Variation in precipitation quality during a 40-hour snowstorm in an urban environment-Denver, Colo., International Journal of Environmental Studies, 28 p.

Schroder, L.J.; Willoughby, T.C.; See, R.B.; and Malo, B.A., 1989, The chemical composition of precipitation, dew and frost, and fog in Denver, Colo., in Atmospheric Deposition, Proceedings of the Baltimore Symposium: Baltimore, Md., May 1989, p. 83.

Shiomi, M.T., and Kuntz, K.W., 1973, Great Lakes precipitation chemistry, Part 1, Lake Ontario Basin, in Proceedings: 16th International Conference on Great Lakes Research, p. 581-602.

U.S. Environmental Protection Agency, 1992, Drinking water regulations and health advisories: Washington, D.C., U.S. Environmental Protection Agency, $13 \mathrm{p}$.

U.S. Geological Survey, 1991a, Gary Quadrangle, scale 1:24,000.

1991b, Highland Quadrangle, scale 1:24,000. 
SUPPLEMENTAL DATA 


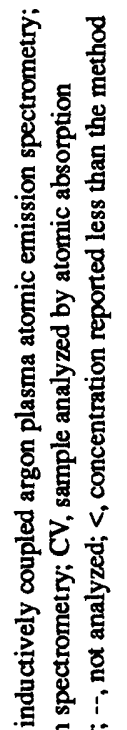

它宫

동

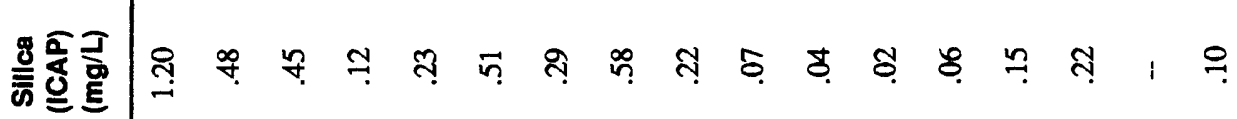

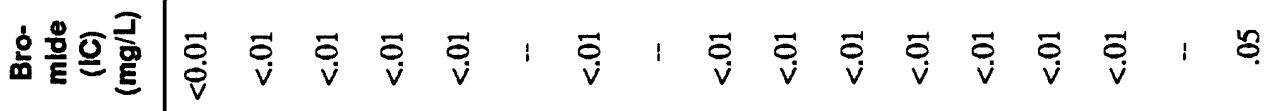
完 힝흔 产部票

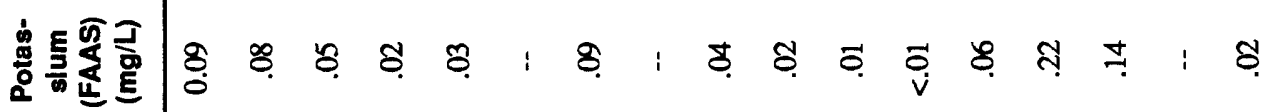

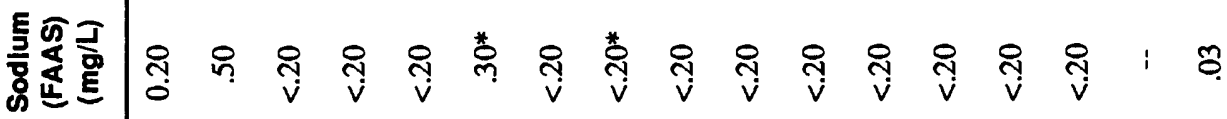

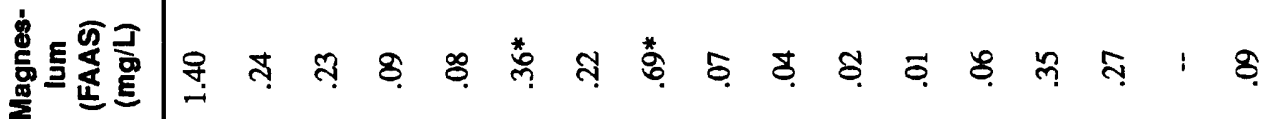
毵要要

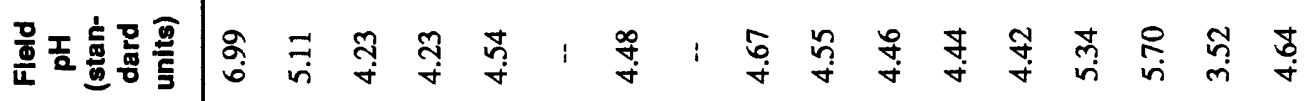

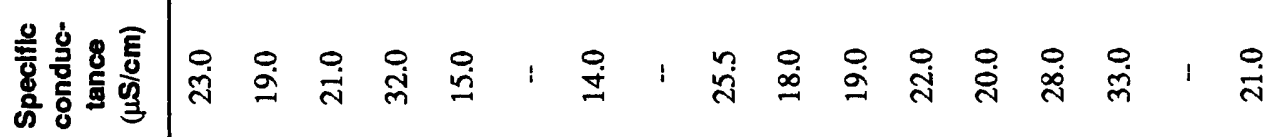
产高竞 E⿱艹亡) 范。

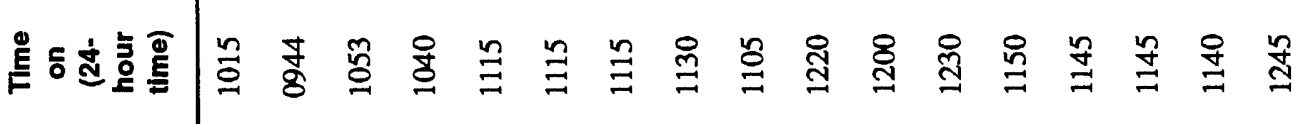
ฐँ 


\begin{tabular}{|c|c|c|c|c|c|c|c|c|c|c|c|c|c|c|c|c|c|c|c|c|c|}
\hline 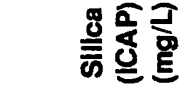 & స్తి & $\stackrel{?}{\hookrightarrow}$ & ஃ̊ & i & $\stackrel{\infty}{0}$ & \& & $\overrightarrow{\mathrm{D}}$ & i & $\stackrel{\infty}{0}$ & ర్ & i & i & $i$ & $\stackrel{?}{?}$ & $\tilde{m}$ & i & $\stackrel{0}{\longleftarrow}$ & $\dddot{?}$ & 8 & $\stackrel{ \pm}{\square}$ & 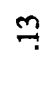 \\
\hline 웁 흘 을 & 㝘 & $\overrightarrow{\mathrm{v}}$ & $!$ & i & $\underset{\mathrm{v}}{\overrightarrow{\mathrm{V}}}$ & ธุ & $\overrightarrow{\stackrel{\vec{v}}{v}}$ & i & 8 & $\overrightarrow{\mathrm{O}}$ & i & i & i & i & o & ' & $\Longrightarrow$ & 1 & $\underset{\mathrm{v}}{\overrightarrow{0}}$ & $\overrightarrow{\dot{v}}$ & $\mathrm{i}$ \\
\hline 은 흔 & $\stackrel{5}{\circ}$ & 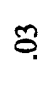 & i & i & ธี & J & $\widetilde{్}$ & 1 & ธิ & o. & 1 & 1 & 1 & 1 & 8 & ! & \&̊․ & i & \& & \% & I \\
\hline 흥 은 을 햍 & ถึ & $\exists$ & i & i & $\stackrel{\infty}{\infty}$ & ন্ড & $\dddot{?}$ & i & $\stackrel{\infty}{\text { ஸे }}$ & $\stackrel{\infty}{=}$ & i & i & i & : & $n$ & i & $\stackrel{\infty}{m}$ & i & 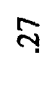 & సి & I \\
\hline 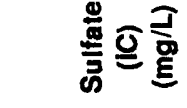 & $\tilde{n}$ & $\vec{i}$ & ' & i & $\stackrel{\Upsilon}{-}$ & 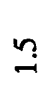 & 9 & i & $\stackrel{\infty}{\sim}$ & $\stackrel{+}{\rightarrow}$ & i & i & i & 1 & $\stackrel{q}{\dot{*}}$ & i & $\stackrel{b}{\forall}$ & i & $\vec{i}$ & $\stackrel{\infty}{n}$ & 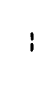 \\
\hline 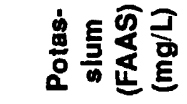 & 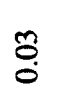 & ธี & i & $i$ & ธ్ & ธุ & 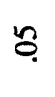 & i & \% & $\underset{\dot{v}}{\vec{v}}$ & i & 1 & $i$ & $i$ & s. & i & ฮี & $i$ & o. & 5 & i \\
\hline 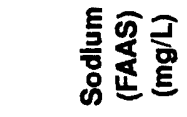 & ठ্ণ & ర & 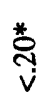 & 1 & ๗े & $\stackrel{0}{?}$ & $\because$ & 1 & $\stackrel{\infty}{=}$ & $\because$ & i & i & 1 & ํํำ & ల్లి & 1 & ్ㅗㅂ & స్ં & ঙิ & s. & 華 \\
\hline 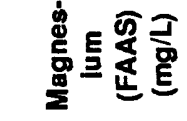 & $\stackrel{m}{0}$ & 5 & 旁 & $i$ & ๕? & ষ & ชै & ! & ষ & ธิ & i & i & i & $\stackrel{*}{\stackrel{*}{0}}$ & สุ & i & 8 & $\stackrel{n}{?}$ & 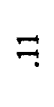 & 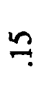 & 苛 \\
\hline 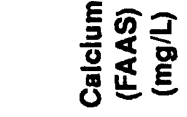 & @ొ & 8 & $\stackrel{0}{\infty}$ & 1 & ণొ & $\cong$ & $\dddot{?}$ & i & $\approx ్$ & $\stackrel{\infty}{0}$ & i & I & i & 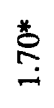 & ભి & 1 & $\infty$ & . & $m$ & gे & $\stackrel{*}{\Xi}$ \\
\hline 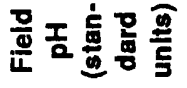 & $\underset{⿱}{\dot{*}}$ & $\stackrel{\circ}{\circ}$ & f̊ & ָ̃ & $\underset{\forall}{F}$ & $\underset{\nabla}{F}$ & $\stackrel{n}{\forall}$ & $\begin{array}{l}\infty \\
\infty \\
\oplus\end{array}$ & ঙ্ণি & $\begin{array}{l}\text { ñ } \\
\text { nin }\end{array}$ & $\begin{array}{l}\stackrel{\Phi}{\Phi} \\
\text { mi }\end{array}$ & $\begin{array}{l}\vec{b} \\
\dot{m}\end{array}$ & $\tilde{n}$ & $i$ & $\vec{F}$ & $\stackrel{n}{n}$ & 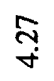 & $\underset{\forall}{\mathbb{J}}$ & $\begin{array}{l}8 \\
\dot{+}\end{array}$ & 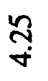 & $\stackrel{n}{f}$ \\
\hline 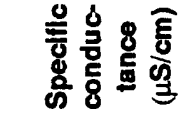 & $\stackrel{\circ}{\circ}$ & 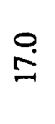 & : & : & $\stackrel{\circ}{\ddot{n}}$ & $\stackrel{0}{\ddot{g}}$ & ஸे & i & $\begin{array}{l}\circ \\
\text { aे }\end{array}$ & $\begin{array}{l}\ddot{y} \\
\ddot{y}\end{array}$ & i & : & I & 1 & 仓े & i & $\begin{array}{l}\text { مें } \\
\text { ले }\end{array}$ & 1 & $\tilde{n}$ & $\stackrel{0}{\dot{\sigma}}$ & i \\
\hline 造 & $\frac{0}{2}$ & 용 & $\underset{\sim}{\infty}$ & $\stackrel{\infty}{0}$ & : & \%) & ऊิ & જે & 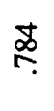 & $\stackrel{2}{\leftrightarrows}$ & $\overline{8}$ & ర్ & $\tilde{\sigma}$ & $\underset{?}{\mathbb{6}}$ & 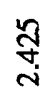 & $\overline{8}$ & $\stackrel{\substack{\infty \\
+}}{\sim}$ & $\stackrel{n}{n}$ & $\stackrel{\mathscr{L}}{\stackrel{7}{*}}$ & 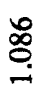 & ถి \\
\hline 异 : & $\stackrel{n}{\approx}$ & 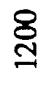 & $\stackrel{n}{\beth}$ & $\stackrel{\curvearrowleft}{=}$ & ¿્స & $\stackrel{n}{\Xi}$ & $\stackrel{\mathfrak{g}}{\exists}$ & $\stackrel{n}{\beth}$ & 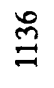 & $\stackrel{ }{\text { ㄱ }}$ & $\stackrel{\Re}{=}$ & $\stackrel{8}{=}$ & $\stackrel{\text { O }}{=}$ & 웅 & $\stackrel{n}{0}$ & ల్ల & శิ & $\frac{n}{8}$ & 웅 & 웅 & 응 \\
\hline$\overline{\bar{\sigma}} \overline{0}$ & $\stackrel{亏}{ٍ}$ & $\stackrel{\aleph}{\stackrel{\Sigma}{\Xi}}$ & 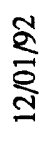 & 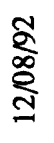 & 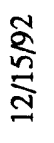 & 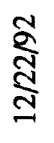 & నิ & 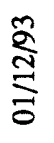 & $\underset{\sigma}{\stackrel{m}{\sigma}}$ & ڤ్ & 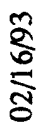 & 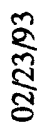 & 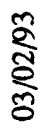 & 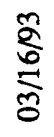 & 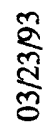 & 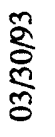 & $\begin{array}{l}\text { } \\
\frac{\delta}{\delta} \\
\frac{\delta}{\delta}\end{array}$ & 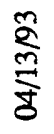 & $\frac{\text { }}{\delta}$ & $\frac{n}{\delta}$ & $\sum_{\frac{n}{\delta}}^{n}$ \\
\hline 点 ธ & $\stackrel{\check{m}}{=}$ & $\stackrel{\mathscr{Z}}{\text { I }}$ & ర্స్ & 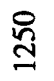 & $\stackrel{ }{\varrho}$ & 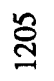 & $\frac{n}{3}$ & 옳 & $\stackrel{n}{\beth}$ & 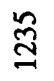 & $\stackrel{n}{\Xi}$ & $\stackrel{\cong}{\Xi}$ & $\stackrel{ }{\stackrel{ }{二}}$ & \& & $\stackrel{8}{8}$ & $\stackrel{ }{\equiv}$ & $\underset{g}{g}$ & हू & 응 & 응 & $\tilde{\sigma}$ \\
\hline$\pi$ & 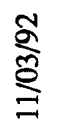 & $\underset{ٍ}{\stackrel{\delta}{O}}$ & $\underset{\Xi}{\stackrel{\Im}{J ~}}$ & 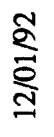 & 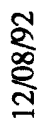 & 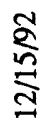 & 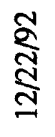 & 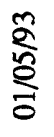 & 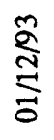 & 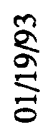 & 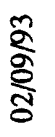 & 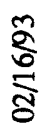 & ๙ิ & $\frac{\kappa}{\hat{\delta}}$ & $\frac{\sum_{0}^{2}}{\stackrel{\delta}{\delta}}$ & กิ & हू & 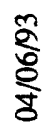 & $\sum_{\frac{m}{\delta}}^{n}$ & 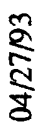 & रे \\
\hline
\end{tabular}




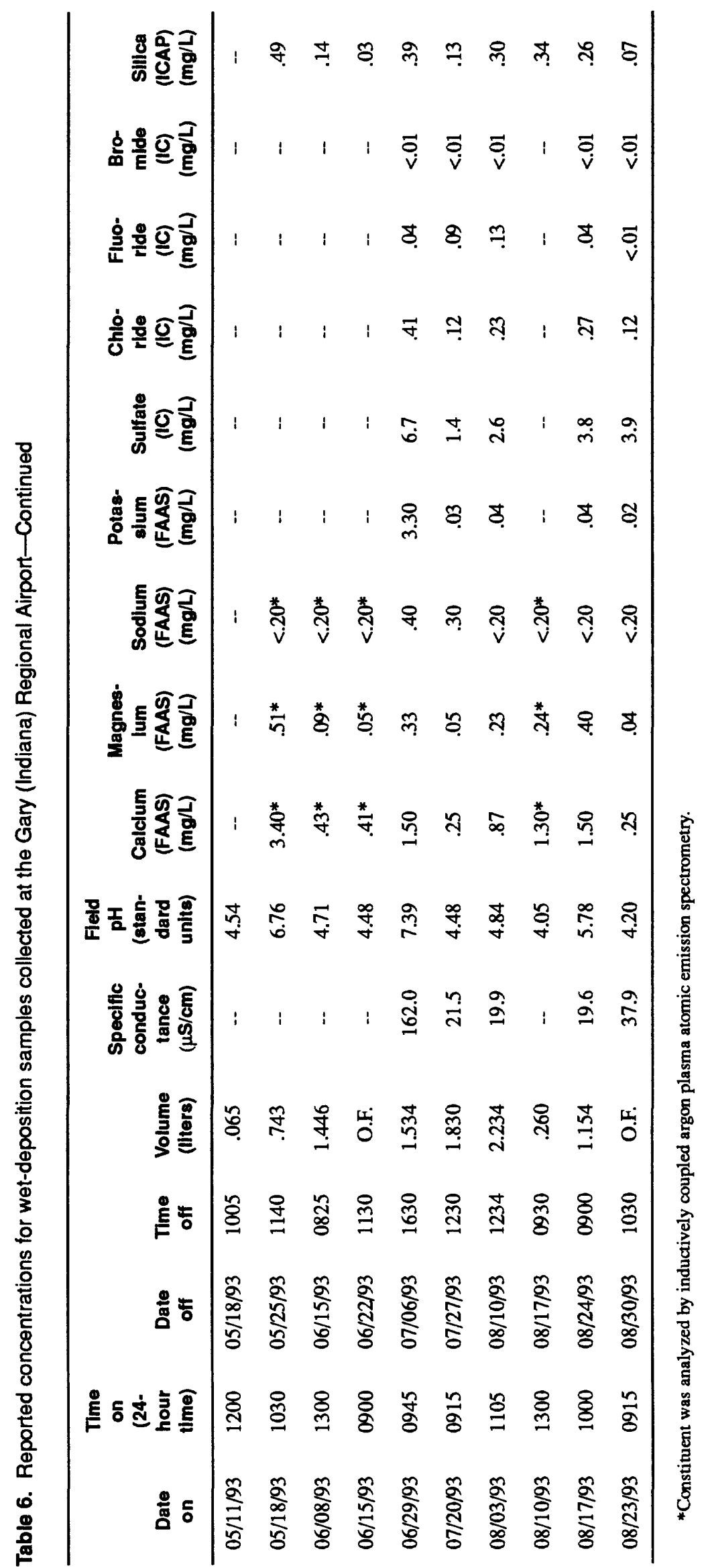




\begin{tabular}{|c|c|c|c|c|c|c|c|c|c|c|c|c|c|c|c|c|c|c|c|c|c|}
\hline 造高 & $\vec{i}$ & $\dddot{m}$ & $\exists$ & $\vec{m}$ & $\stackrel{\infty}{i}$ & $\widetilde{ה}$ & $\stackrel{\circlearrowright}{\ddot{r}}$ & $\stackrel{\square}{\leftrightarrows}$ & $\tilde{n}$ & $\vec{i}$ & ? & $\stackrel{\infty}{\infty}$ & $\vec{m}$ & $\stackrel{\circ}{\circ}$ & $\stackrel{\Upsilon}{-}$ & : & $\exists$ & $\stackrel{\circ}{-}$ & $\stackrel{0}{-}$ & $\exists$ & i \\
\hline 息 & $\mathscr{v}$ & $\stackrel{\mathscr{V}}{V}$ & $\stackrel{\mathscr{V}}{\mathrm{V}}$ & $\mathscr{v}$ & $\stackrel{\nabla}{v}$ & $\mathscr{V}$ & $\stackrel{\nabla}{V}$ & $\stackrel{\mathscr{v}}{\mathrm{v}}$ & $\stackrel{8}{v}$ & $\stackrel{P}{v}$ & $\stackrel{\mathscr{V}}{ }$ & $\stackrel{\mathscr{V}}{\mathrm{V}}$ & $\stackrel{\mathscr{V}}{V}$ & $\stackrel{P}{V}$ & v & $!$ & $\mathscr{V}$ & $\stackrel{\sim}{v}$ & $\stackrel{P}{V}$ & $\stackrel{?}{v}$ & $:$ \\
\hline 它 & $\stackrel{0}{0}$ & $\ddot{i}$ & $\stackrel{\leftrightarrow}{\sim}$ & a & $\eta$ & $\stackrel{0}{m}$ & 9 & $\stackrel{\circ}{\dot{*}}$ & $\stackrel{\circ}{\stackrel{f}{*}}$ & $\eta$ & o. & $\stackrel{n}{v}$ & ? & $\stackrel{\circ}{\dot{m}}$ & $\stackrel{\infty}{\infty}_{\infty}$ & 1 & $\eta$ & $\stackrel{\circ}{m}$ & $n$ & $\stackrel{i}{i}$ & $i$ \\
\hline 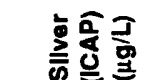 & $\vec{v}$ & $\vec{v}$ & $\vec{v}$ & $\vec{v}$ & $\vec{v}$ & $\vec{v}$ & $\vec{v}$ & $\vec{v}$ & $\vec{v}$ & $\vec{v}$ & $\vec{v}$ & $\vec{v}$ & $\vec{v}$ & $\vec{v}$ & $\vec{v}$ & i & $\vec{v}$ & $\vec{v}$ & $\vec{v}$ & $\vec{v}$ & $i$ \\
\hline 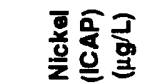 & $\stackrel{\circ}{\vec{v}}$ & $\stackrel{\circ}{\vec{v}}$ & $\stackrel{\circ}{\vec{v}}$ & $\stackrel{\circ}{\vec{v}}$ & $\stackrel{\circ}{\vec{v}}$ & $\stackrel{\circ}{\vec{v}}$ & $\stackrel{\circ}{\vec{v}}$ & $\stackrel{\circ}{\vec{v}}$ & $\stackrel{\circ}{\vec{v}}$ & $\stackrel{\vec{v}}{v}$ & $\stackrel{\circ}{\mathrm{v}}$ & $\stackrel{\circ}{\vec{v}}$ & $\stackrel{0}{\vec{v}}$ & $\stackrel{\circ}{\vec{v}}$ & $\stackrel{\circ}{\vec{v}}$ & $i$ & $\stackrel{\circ}{\vec{v}}$ & $\stackrel{O}{\vec{v}}$ & $\stackrel{\circ}{\vec{v}}$ & $m$ & i \\
\hline 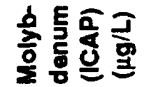 & 은 & 음 & $\stackrel{ }{\vec{v}}$ & $\stackrel{\circ}{v}$ & $\stackrel{\circ}{\vec{v}}$ & $\stackrel{\circ}{\vec{v}}$ & $\stackrel{O}{v}$ & $\stackrel{\vec{v}}{v}$ & $\stackrel{\vec{v}}{v}$ & $\stackrel{\partial}{v}$ & $\stackrel{O}{v}$ & $\stackrel{\circ}{v}$ & $\stackrel{\vec{v}}{v}$ & $\stackrel{\circ}{\vec{v}}$ & $\stackrel{\vec{v}}{\vec{v}}$ & $\mathrm{i}$ & $\stackrel{\circ}{\vec{v}}$ & 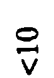 & $\stackrel{\circ}{\mathrm{v}}$ & $\stackrel{\vec{v}}{v}$ & i \\
\hline & $\overrightarrow{8}$ & $\vec{v}$ & $\vec{v}$ & $\vec{v}$ & $\vec{v}$ & i & $\vec{v}$ & : & $\vec{v}$ & $\vec{v}$ & $\vec{v}$ & $\vec{v}$ & $\vec{v}$ & ! & $\vec{v}$ & i & $\vec{v}$ & $\vec{v}$ & $\vec{v}$ & i & i \\
\hline 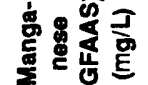 & 웅 & $\stackrel{\circ}{9}$ & $\stackrel{\circ}{\infty}$ & $g$ & $\overrightarrow{6}$ & $\ddot{9}$ & $\stackrel{\circ}{=}$ & ஜ̊̀. & $\ddot{n}$ & i̊. & $\pi$ & 9 & $\stackrel{\sim}{n}$ & $\stackrel{0}{\infty}$ & ஜ் & $i$ & $\stackrel{\circ}{\dot{\Xi}}$ & $\stackrel{m}{r}$ & ஜํ. & ஜํ. & i \\
\hline 疍 & $\mathbb{V}$ & $\forall$ & $\vec{v}$ & $\forall$ & $\ddot{V}$ & $\vec{v}$ & $\forall$ & $\forall$ & $\dot{v}$ & $\dot{V}$ & $\underset{v}{ }$ & $\forall$ & $\nabla$ & $\nabla$ & $\dot{v}$ & 1 & $\vec{V}$ & $\dot{v}$ & $\ddot{v}$ & $\dot{v}$ & 1 \\
\hline & $\hat{\infty}$ & $\varphi$ & $\infty$ & $\dddot{n}$ & $\tilde{v}$ & $\stackrel{\circ}{-}$ & $\infty$ & 웅 & $\stackrel{m}{\sim}$ & $\dddot{m}$ & 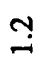 & $r$ & $\stackrel{\infty}{-}$ & $\underset{\forall}{\mathscr{\forall}}$ & $\begin{array}{l}\infty \\
\dot{n} \\
\dot{n}\end{array}$ & 1 & $\dddot{n}$ & $\bar{i}$ & $\stackrel{\infty}{-}$ & $\stackrel{\circ}{\dot{r}}$ & : \\
\hline 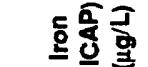 & สิ & $\tilde{a}$ & $\approx$ & $\bar{m}$ & \pm & $\hat{6}$ & $\overrightarrow{6}$ & $\stackrel{\infty}{\infty}$ & ஜి & 으 & $\cong$ & 0 & $\infty$ & $\vartheta$ & n & $i$ & $\overrightarrow{6}$ & i & 2 & $g$ & i \\
\hline 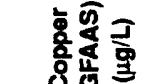 & $\stackrel{\circ}{=}$ & $\vec{i}$ & $\stackrel{\Upsilon}{\sim}$ & $=$ & $\stackrel{i}{i}$ & $\vec{\pi}$ & 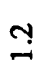 & $\stackrel{\infty}{n}$ & $r$ & $\stackrel{\circ}{-}$ & $\stackrel{\eta}{v}$ & $\mathfrak{v}$ & ? & $\stackrel{m}{\sim}$ & $\overrightarrow{\dot{\sigma}}$ & 1 & $r$ & $\vec{i}$ & $\hat{i}$ & $\stackrel{\circ}{\dot{n}}$ & $i$ \\
\hline 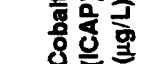 & $\vartheta$ & $\vartheta$ & $\vartheta$ & $\vartheta$ & $\vartheta$ & $\vartheta$ & $\vartheta$ & $\vartheta$ & $\vartheta$ & $\vartheta$ & $\vartheta$ & $\vartheta$ & $\vartheta$ & $\vartheta$ & $\nabla$ & i & $\vartheta$ & $\vartheta$ & $\tilde{v}$ & $\vec{v}$ & $i$ \\
\hline 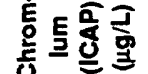 & $v$ & $v$ & 0 & 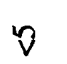 & $v$ & $v$ & $v$ & $v$ & $v$ & 0 & $\vartheta$ & $\vartheta$ & $v$ & $\overrightarrow{\mathrm{N}}$ & $v$ & $i$ & $v$ & $\nabla$ & $\vartheta$ & $\vec{v}$ & $i$ \\
\hline 总题言 & ma & $\vec{v}$ & $\vec{v}$ & $\vec{v}$ & $\vec{v}$ & $\forall$ & $\vec{v}$ & ฯ & $\vec{v}$ & ฯ & $\vec{v}$ & $\vec{v}$ & $\vec{v}$ & ฯ & $\because$ & $!$ & $\vec{v}$ & - & $\rightarrow$ & $\stackrel{\circ}{\dot{*}}$ & i \\
\hline 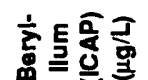 & $\hat{i}$ & $\eta$ & $\mathfrak{n}$ & $n$ & $n$ & $\tilde{v}$ & $q$ & $\eta$ & $\eta$ & 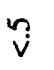 & $\mathfrak{n}$ & $n$ & $\dddot{n}$ & $\mathfrak{v}$ & 울 & i & $\tilde{v}$ & $\eta$ & $\tilde{v}$ & $\tilde{v}$ & $i$ \\
\hline & $\cong$ & $\nabla$ & $\nabla$ & $N$ & $\nabla$ & 0 & $m$ & $r$ & $r$ & $\checkmark$ & $N$ & $\mathcal{V}$ & $\tilde{V}$ & $n$ & $\simeq$ & 1 & $\nabla$ & $r$ & $\mathrm{~N}$ & $m$ & : \\
\hline & $\vec{v}$ & $\vec{v}$ & $\vec{v}$ & $\vec{v}$ & $\vec{v}$ & $\vec{v}$ & $\vec{v}$ & $\vec{v}$ & $\vec{v}$ & $\vec{v}$ & $\vec{v}$ & $\vec{v}$ & $\vec{v}$ & $\vec{v}$ & $\vec{v}$ & : & $\vec{v}$ & $\vec{v}$ & $\vec{v}$ & $\vec{v}$ & i \\
\hline 产总豆 & $\stackrel{\text { ộ }}{\dot{v}}$ & $\underset{\dot{v}}{\text { g }}$ & $\underset{v}{\stackrel{c}{v}}$ & i & $\stackrel{\text { Oo }}{v}$ & i & $\stackrel{\vartheta}{i}$ & $i$ & $\underset{v}{\vartheta}$ & $\underset{\dot{\gamma}}{\tilde{v}}$ & $\stackrel{8}{8}$ & $\underset{\vartheta}{\mathscr{\gamma}}$ & $\stackrel{i}{i}$ & 8 & $\stackrel{g}{i}$ & i & $\underset{v}{\vartheta}$ & $\underset{v}{v}$ & $\stackrel{o}{v}$ & i & i \\
\hline 害豆总 & $\vec{j}$ & $\stackrel{\sim}{m}$ & $\stackrel{n}{n}$ & $\stackrel{m}{i}$ & $\bar{n}$ & $i$ & $\stackrel{n}{=}$ & 1 & $\stackrel{m}{n}$ & $\stackrel{0}{q}$ & $\dddot{m}$ & 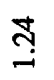 & $\check{n}$ & $\stackrel{m}{\dot{q}}$ & ñ. & : & $\stackrel{n}{g}$ & تِّ & ঙ્త & : & i \\
\hline & $\frac{\aleph}{\delta}$ & $\underset{\delta}{\stackrel{\delta}{\delta}}$ & 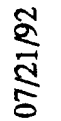 & 芩 & 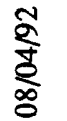 & $\underset{\infty}{\stackrel{\infty}{્}}$ & $\stackrel{\infty}{\infty}_{\infty}^{\infty}$ & 於 & 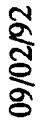 & 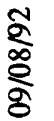 & 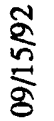 & ふָ & 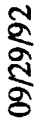 & 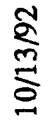 & ふָ & $\frac{\delta}{\delta}$ & 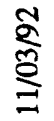 & $\stackrel{\sigma}{\partial}$ & 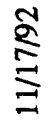 & న్ & 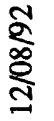 \\
\hline$=$ & §ू & $\underset{\frac{\delta}{\delta}}{\frac{\delta}{\delta}}$ & $\underset{\delta}{\stackrel{N}{\delta}}$ & 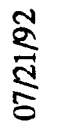 & 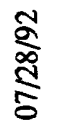 & 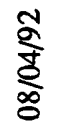 & $\underset{\S}{\lesssim}$ & 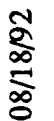 & §ू. & $\frac{\aleph}{\vdots}$ & 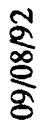 & $\frac{\pi}{2}$ & ふָ & ईั & 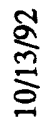 & ふू & 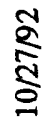 & $\stackrel{\aleph}{\S}$ & $\stackrel{\S}{ٍ}$ & $\begin{array}{c}\text { 亏ू } \\
\stackrel{\text { ป }}{\Xi}\end{array}$ & 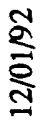 \\
\hline
\end{tabular}




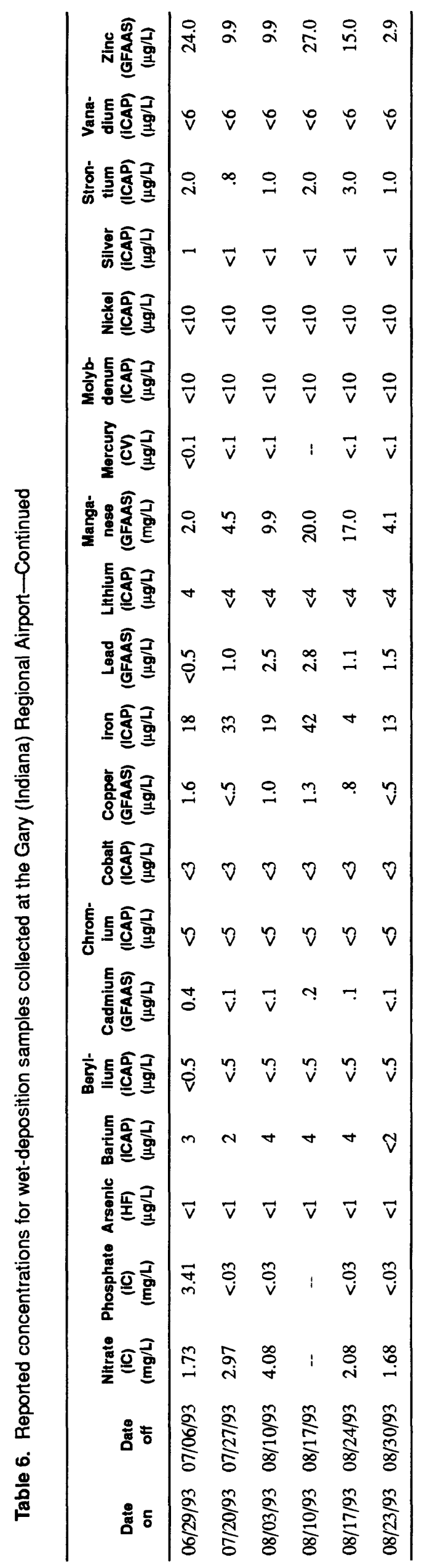




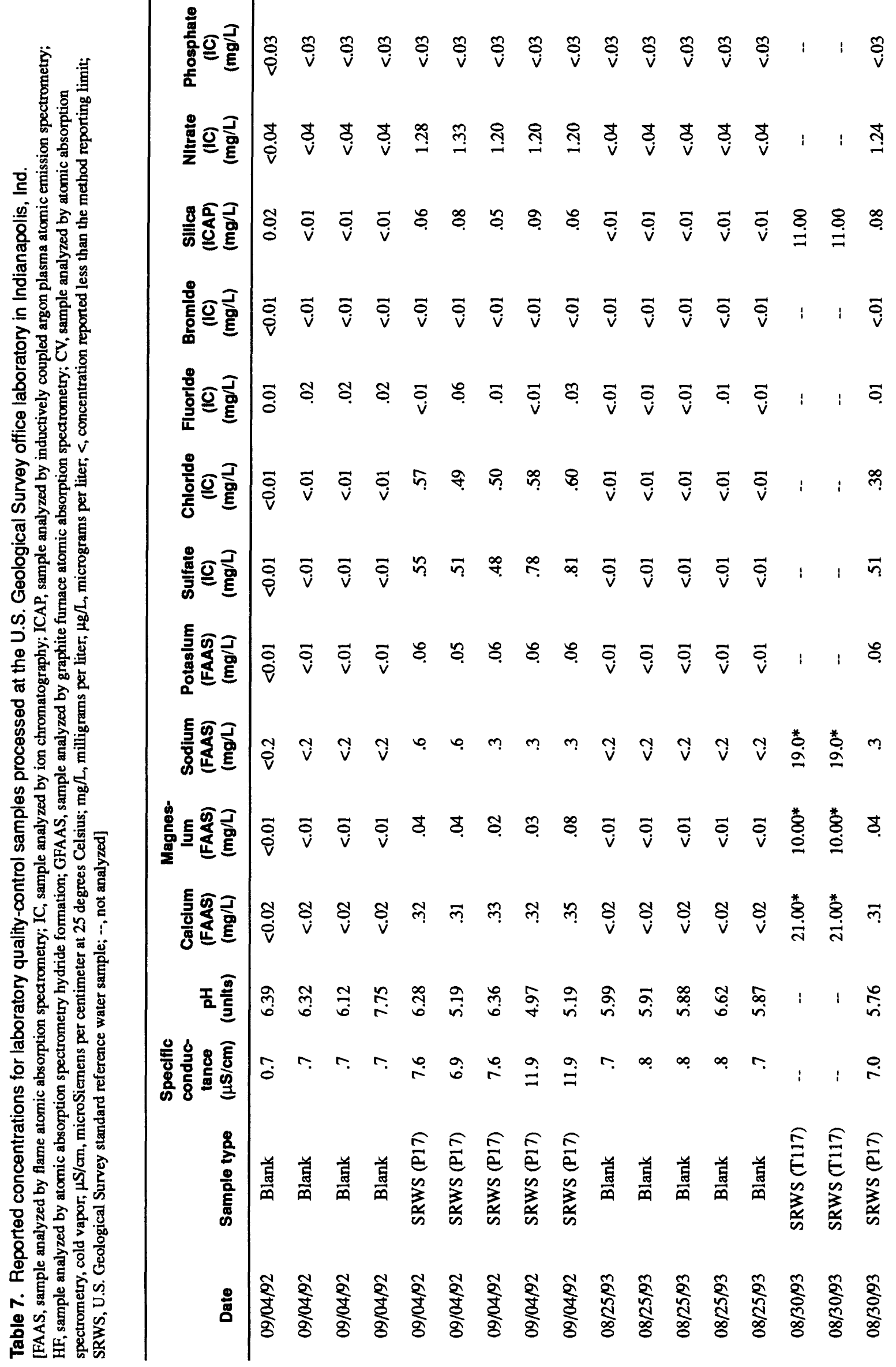




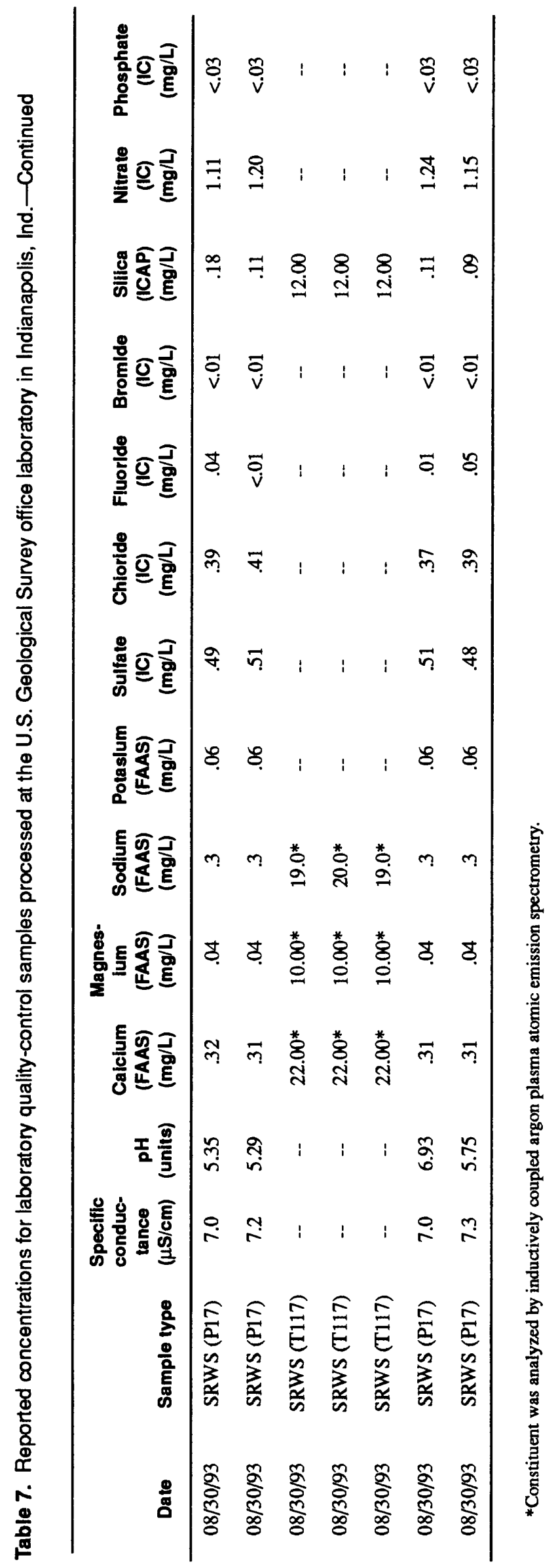




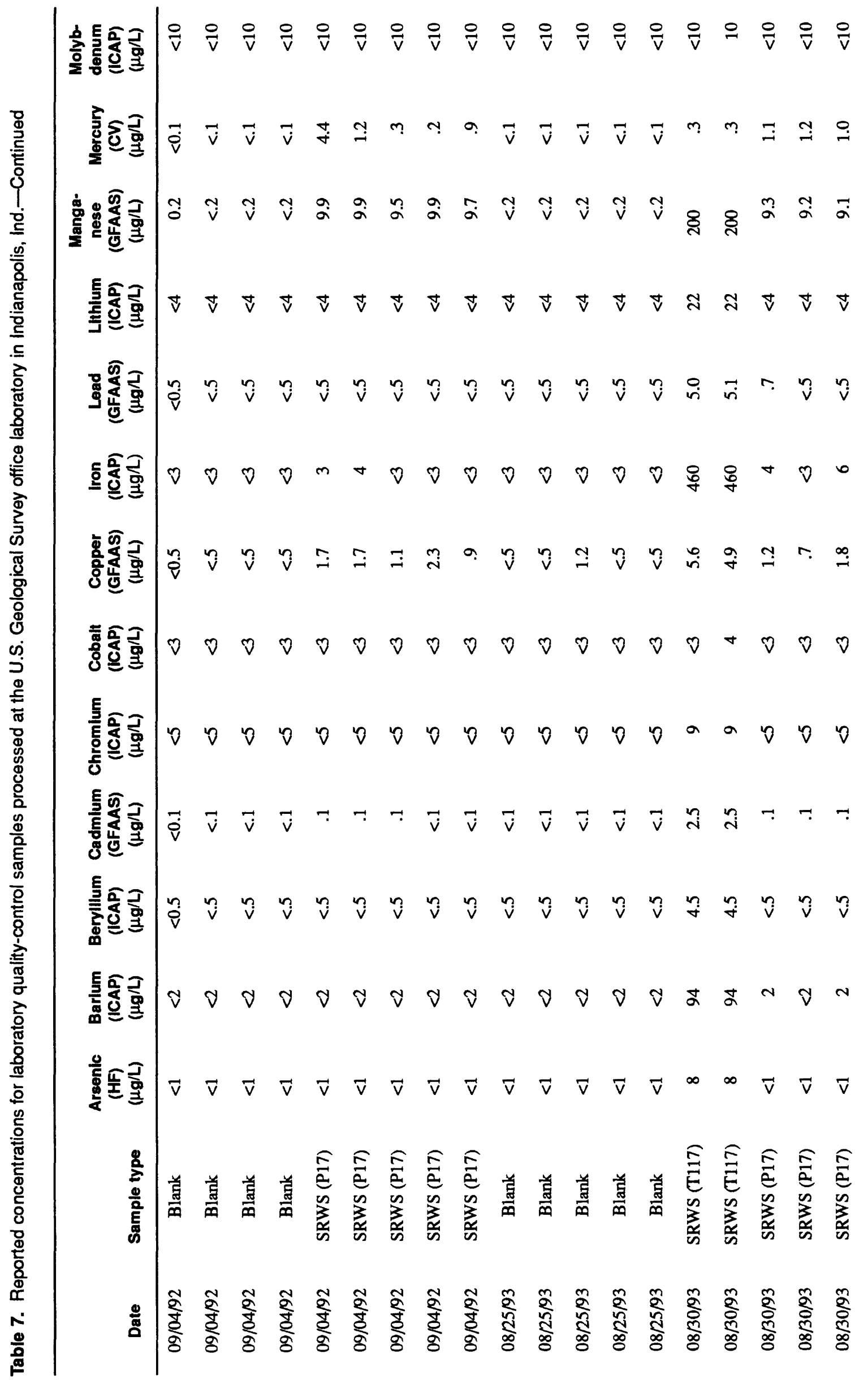




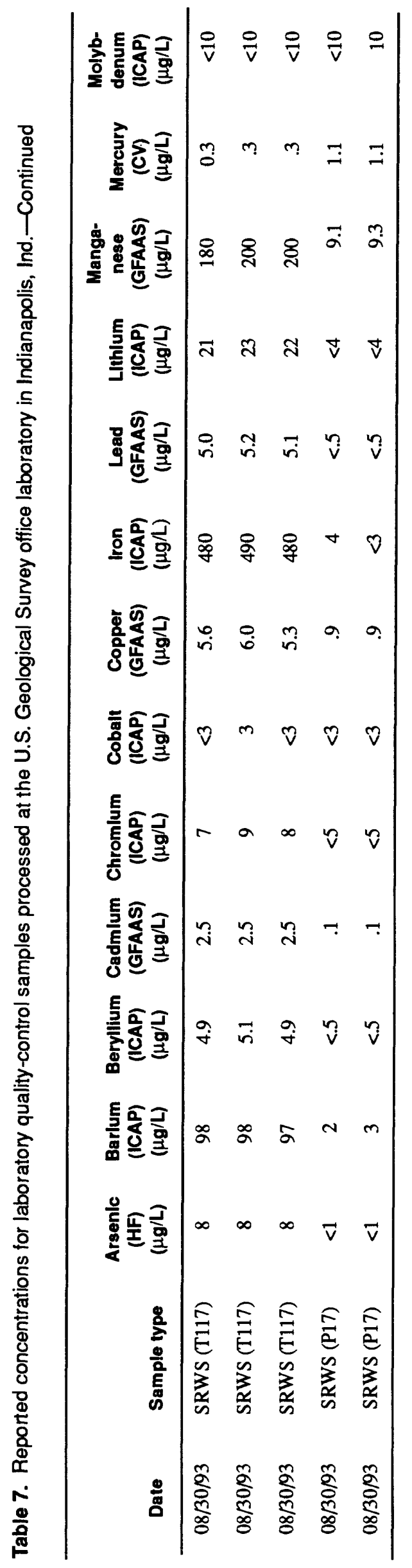




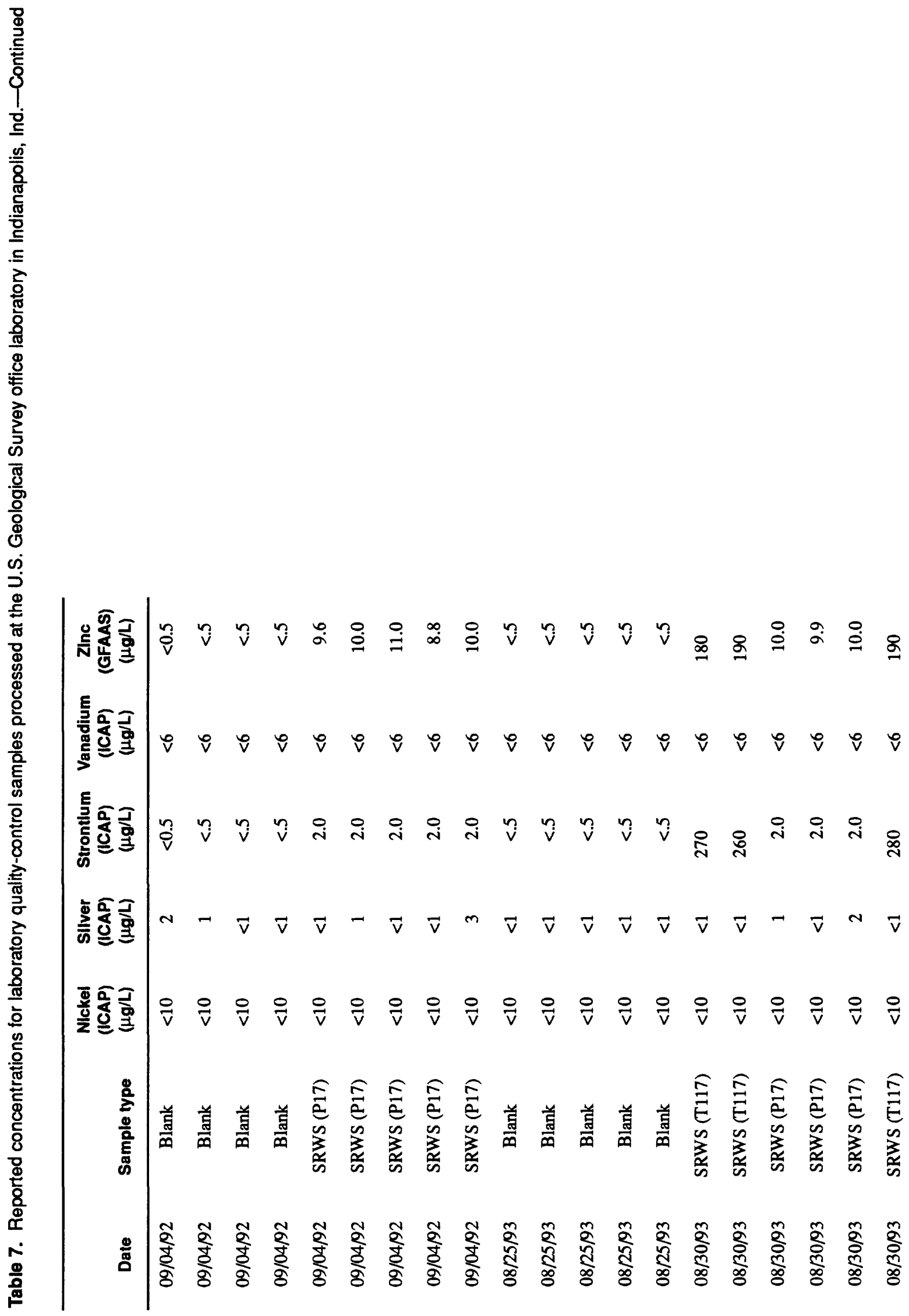




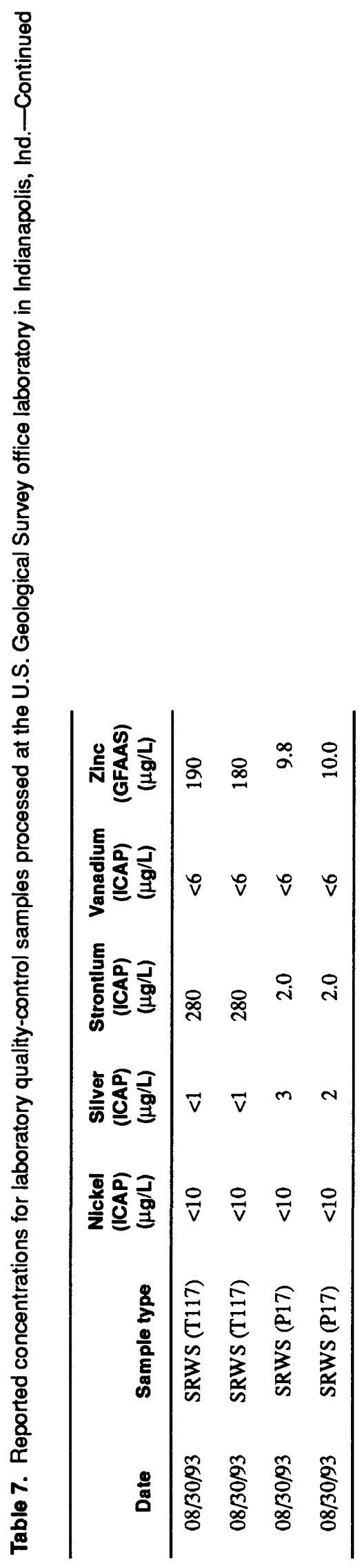




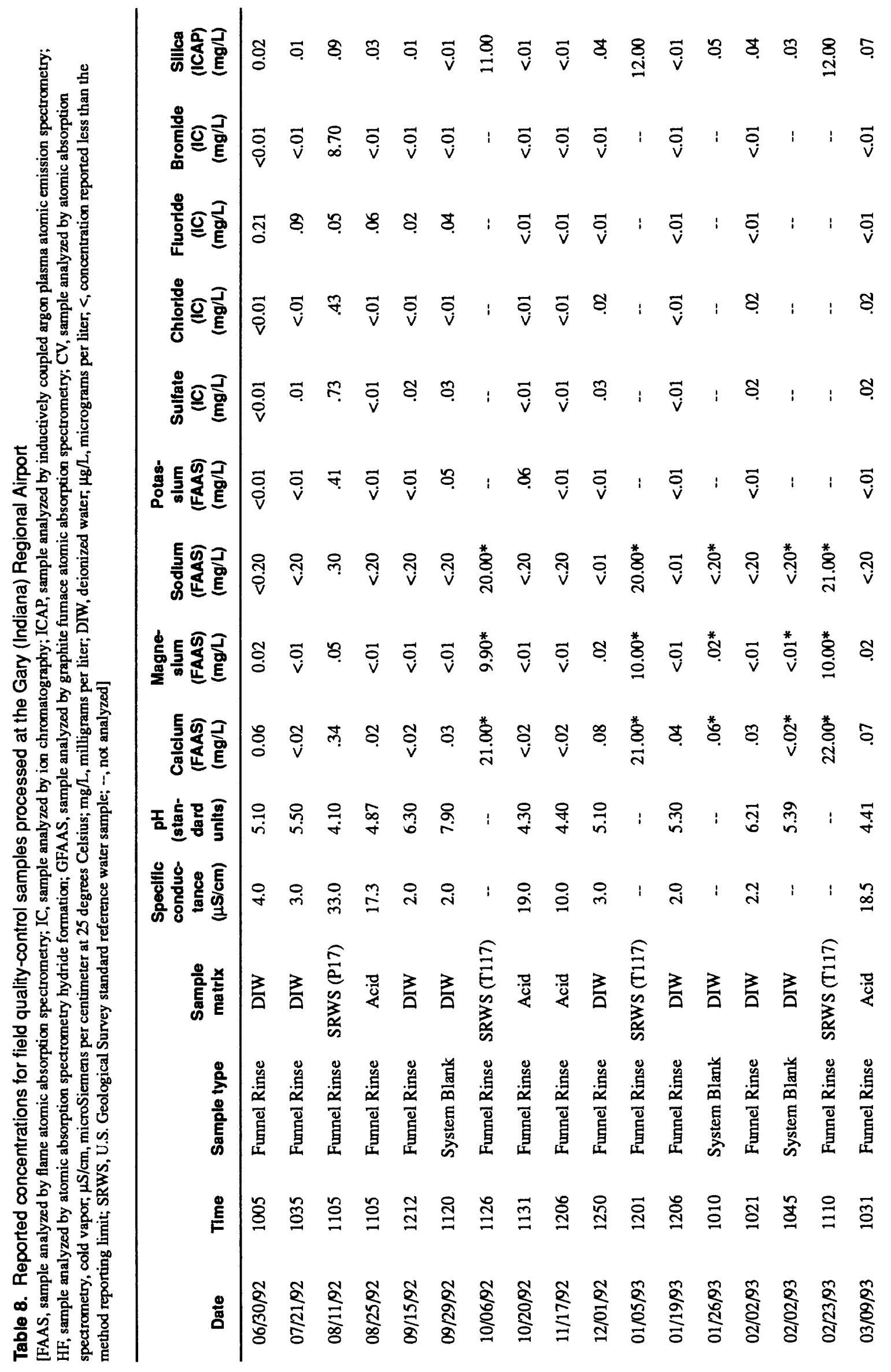




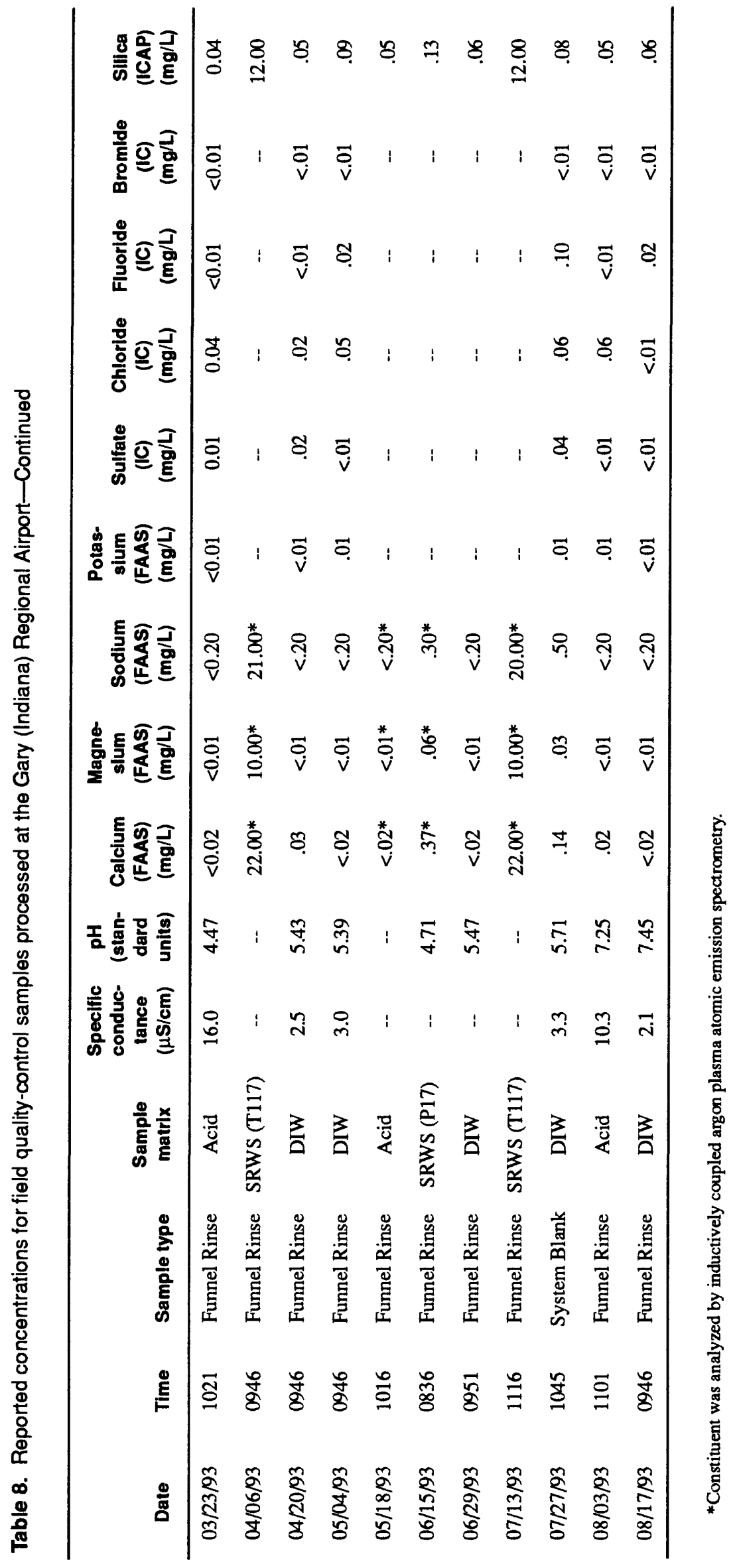




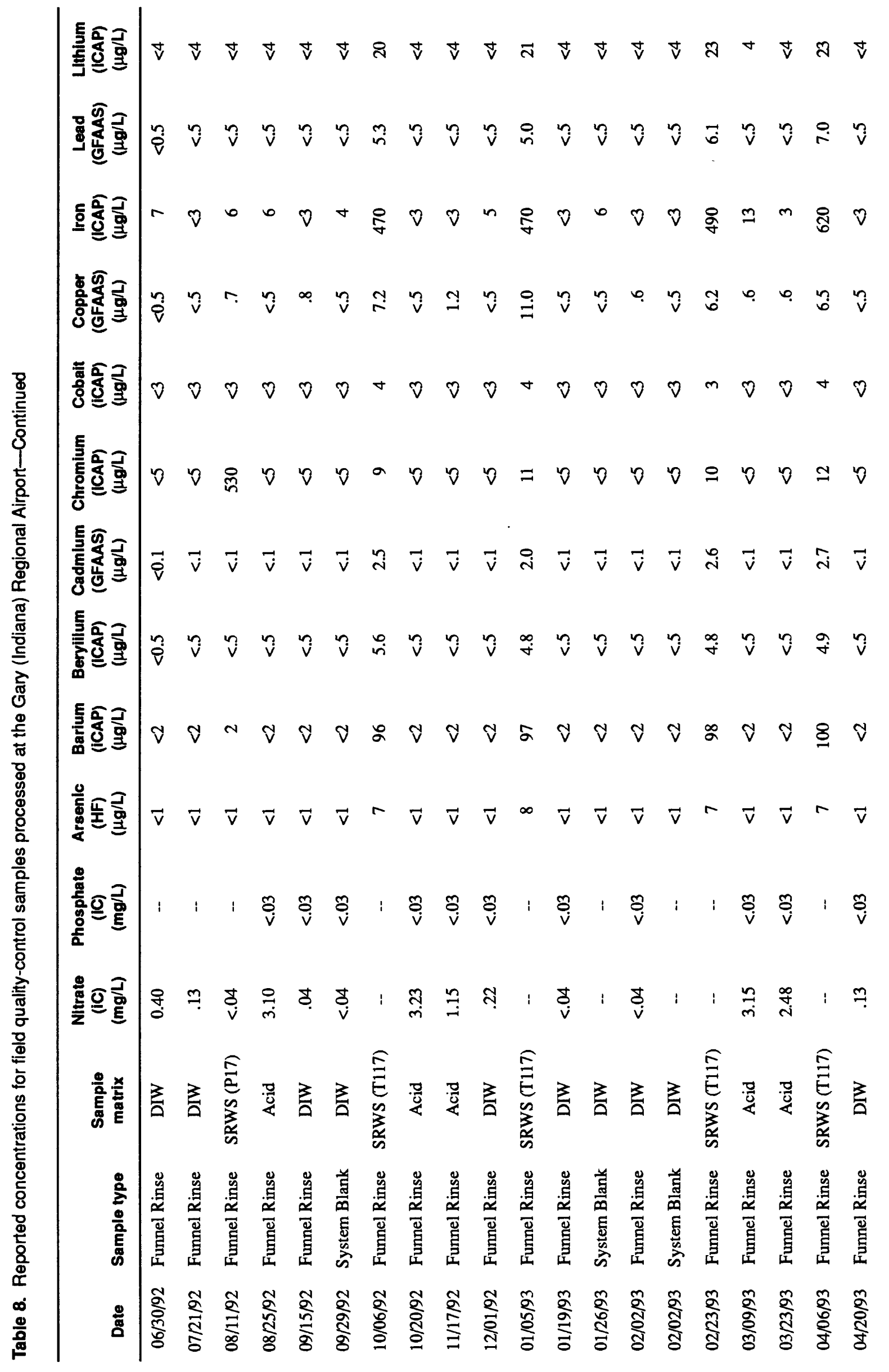




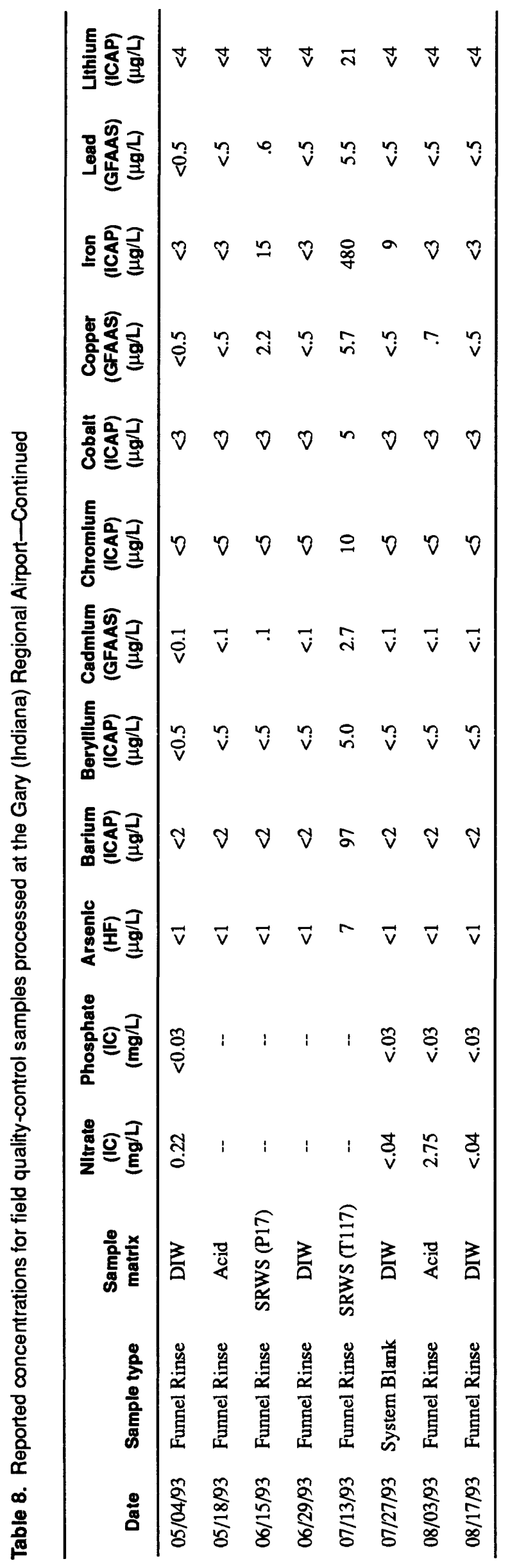




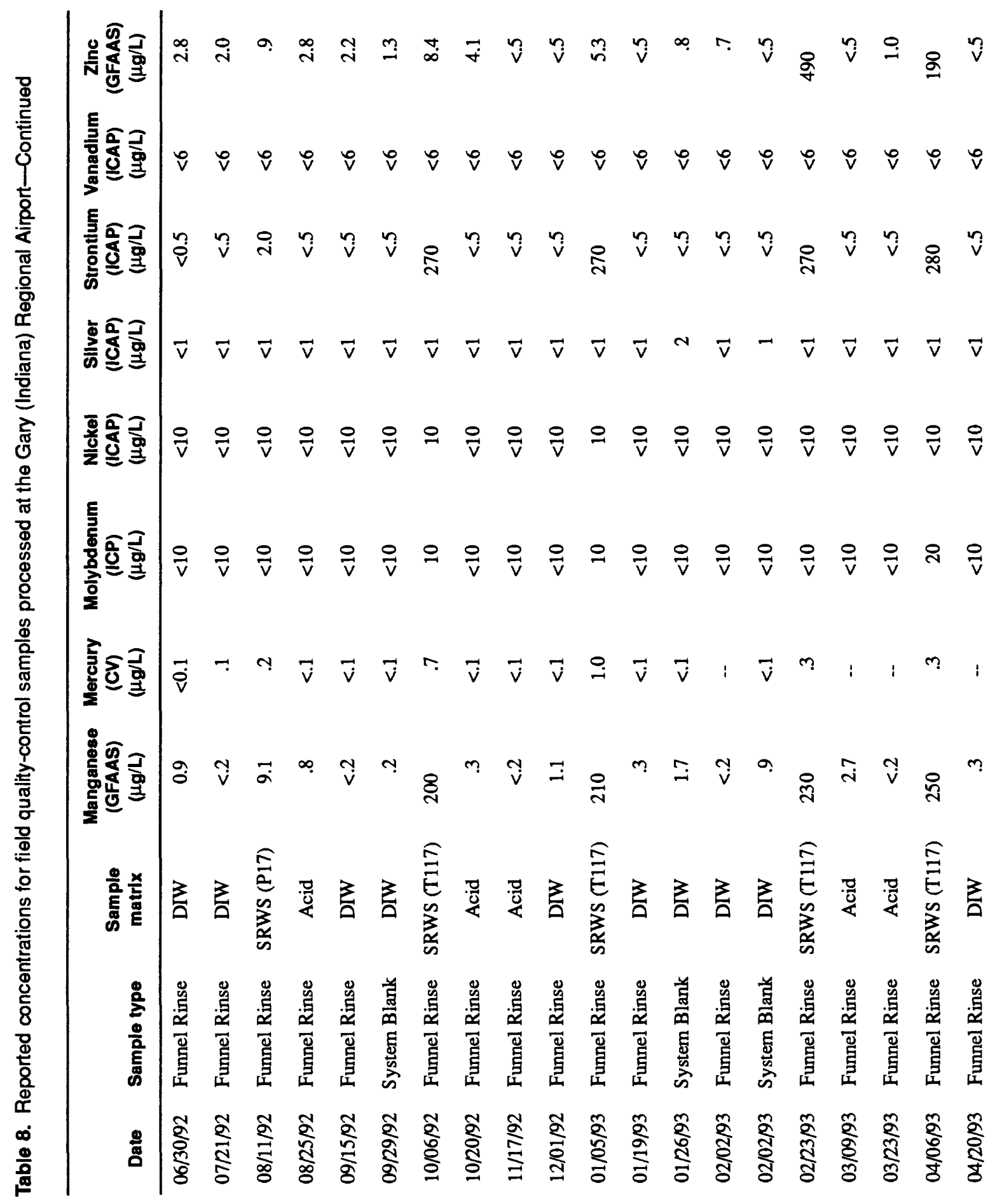




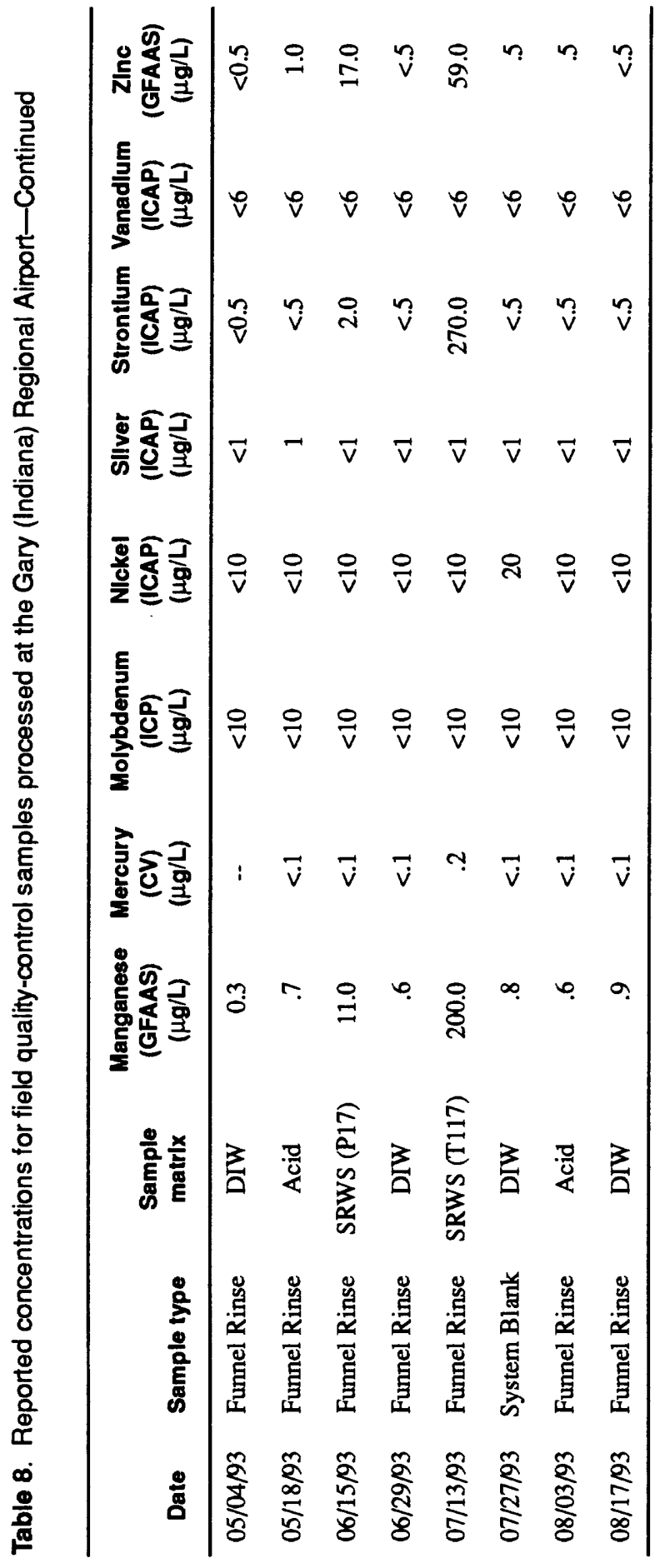

